Hu- Liblar.

Grem Bamar keel

Garilie Parh A whorin

$$
\text { PO. Bax } 1379
$$

Townswilic 4810 

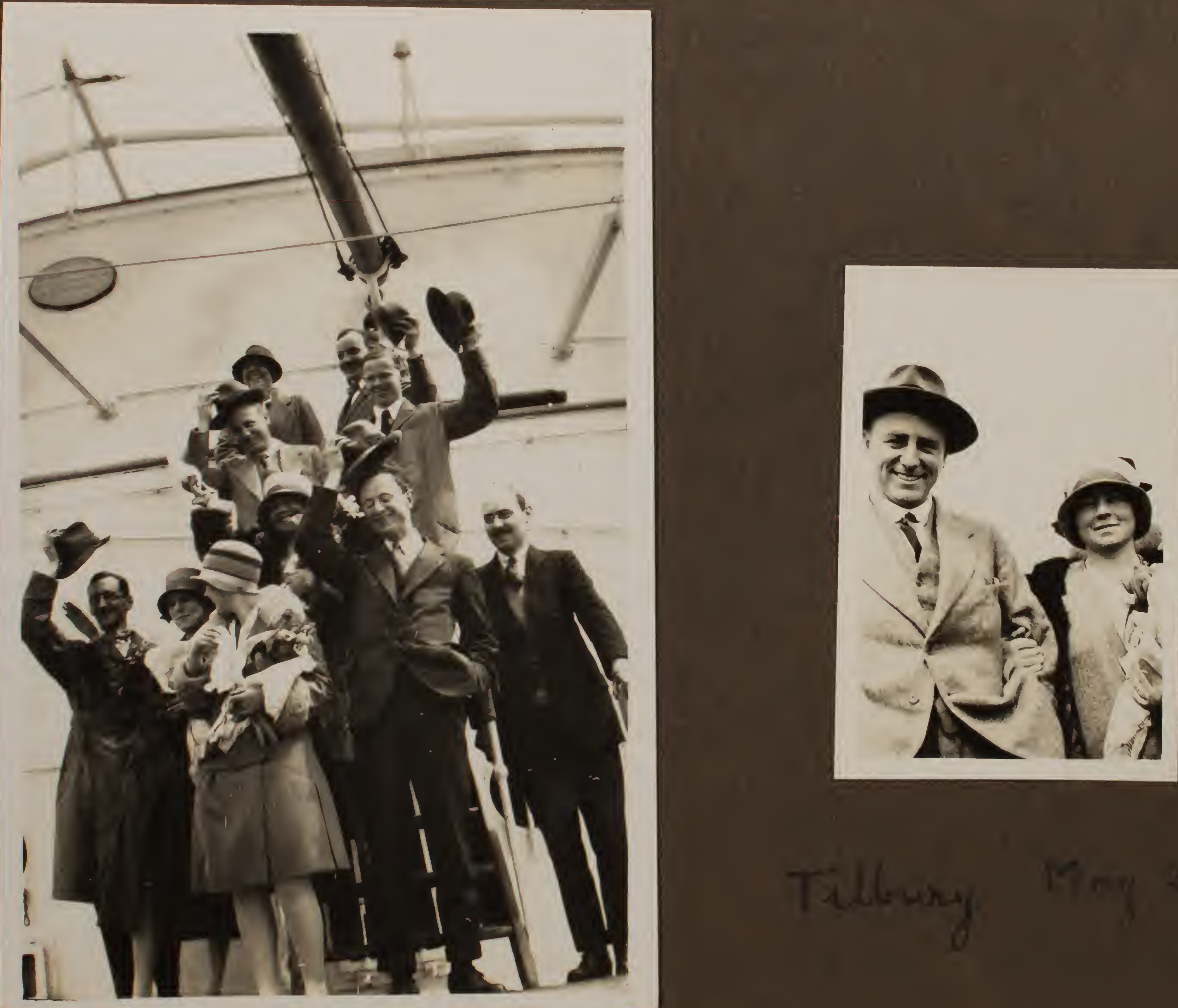

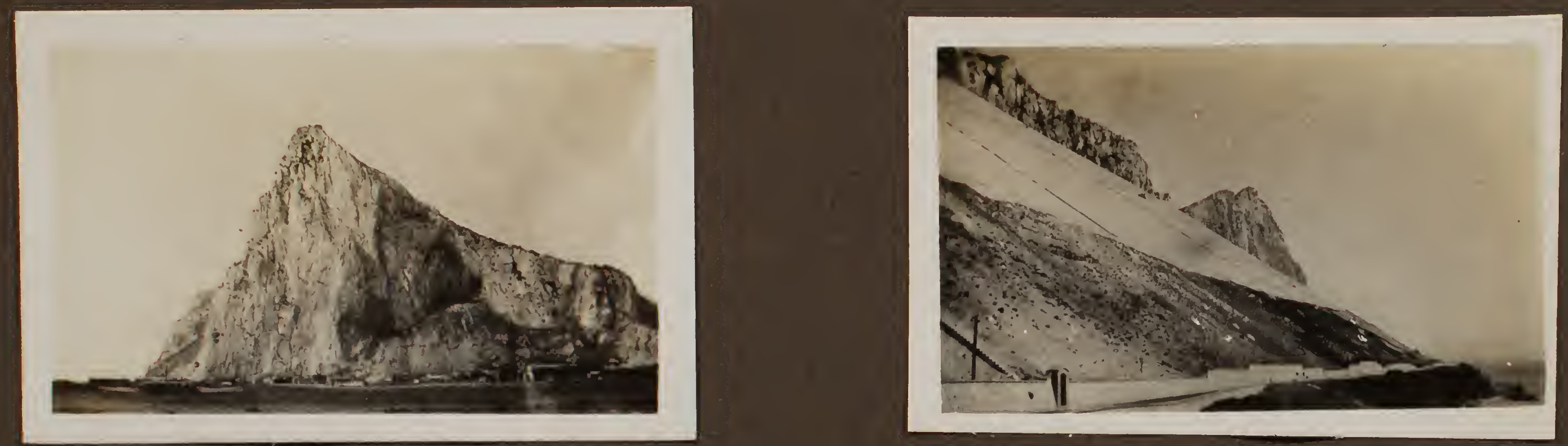

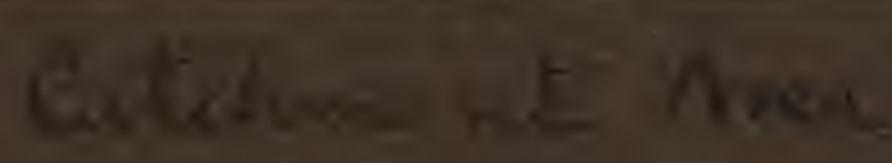
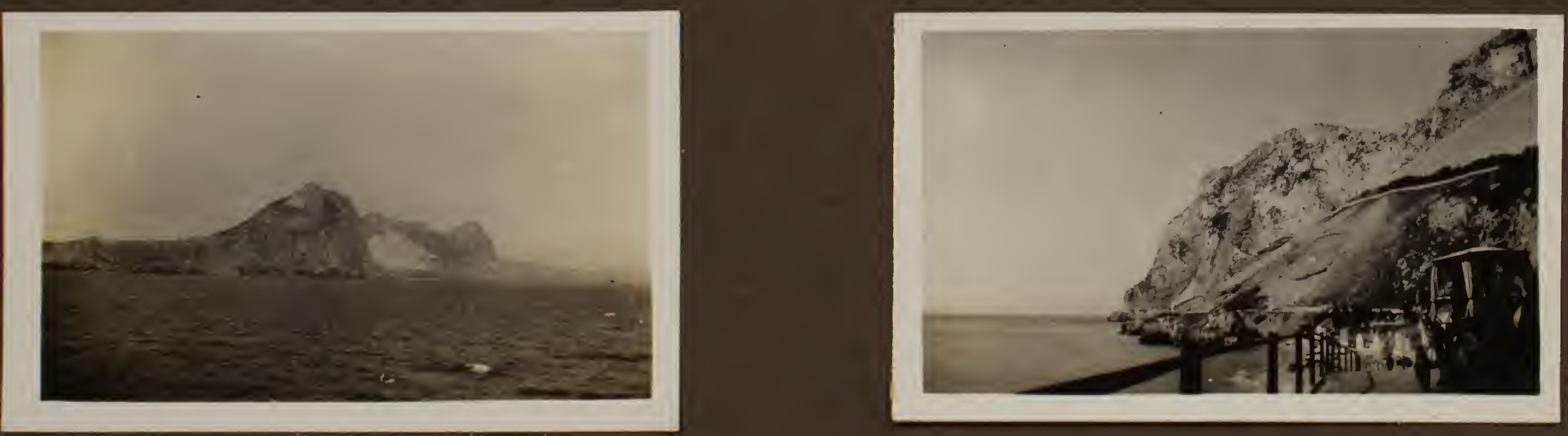

\section{Gitraitar 30.828}



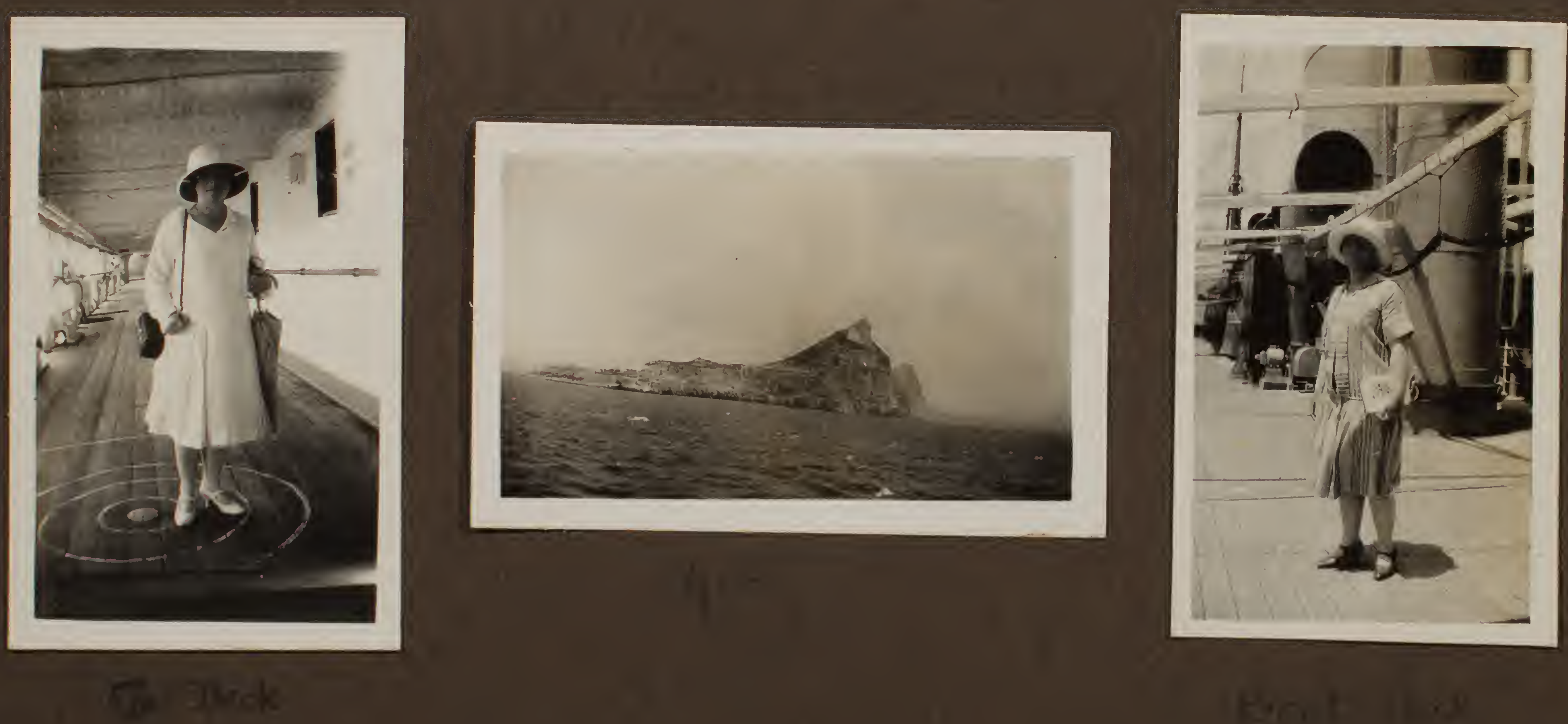

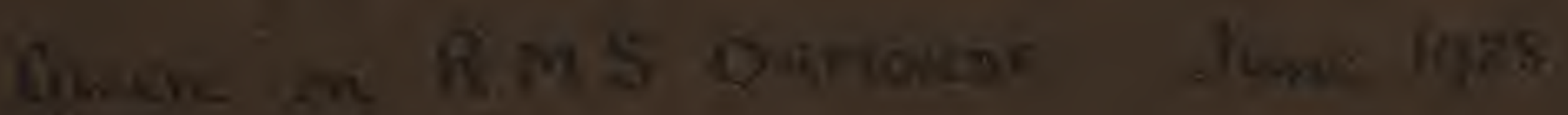




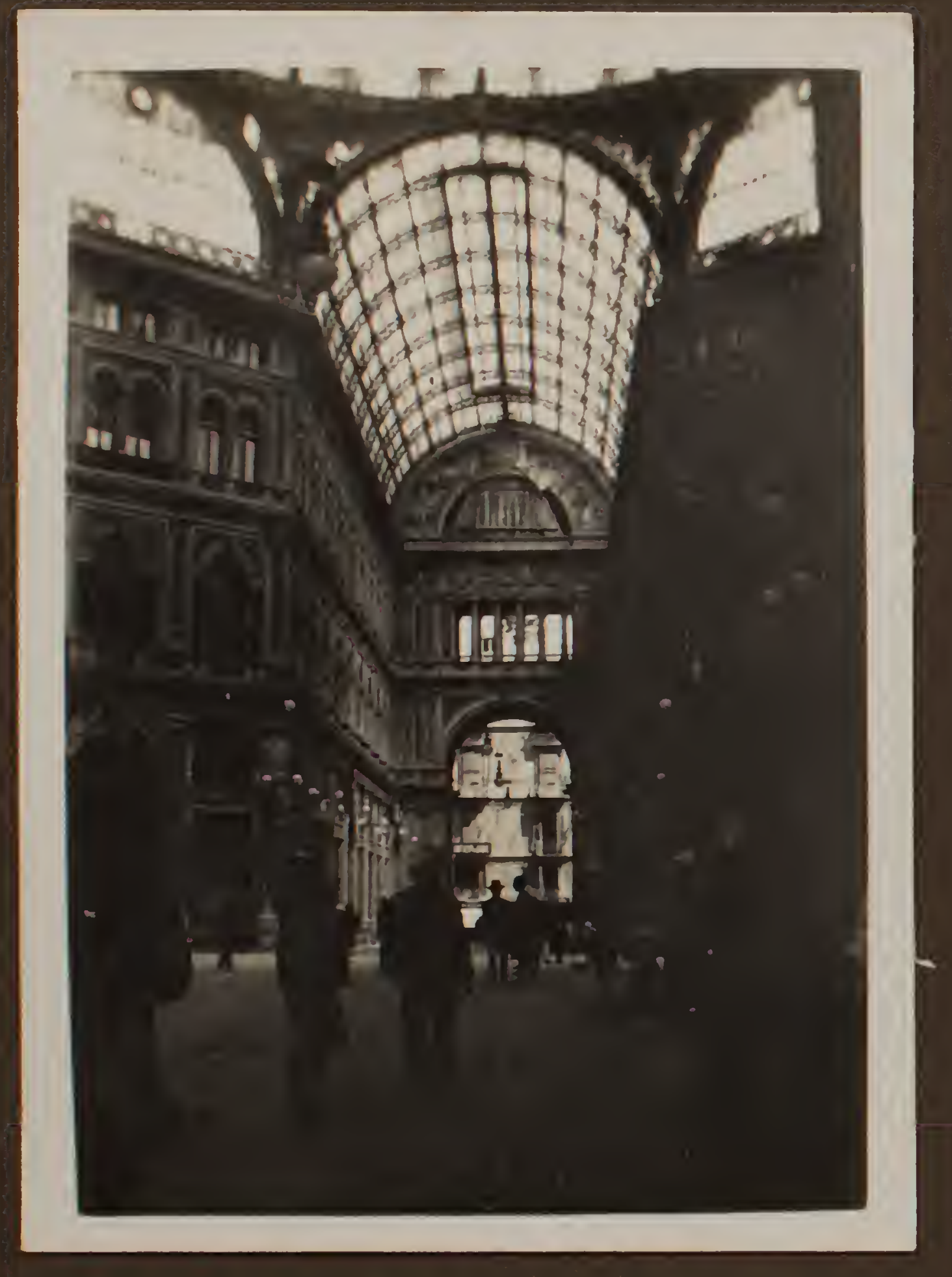

Arcade.

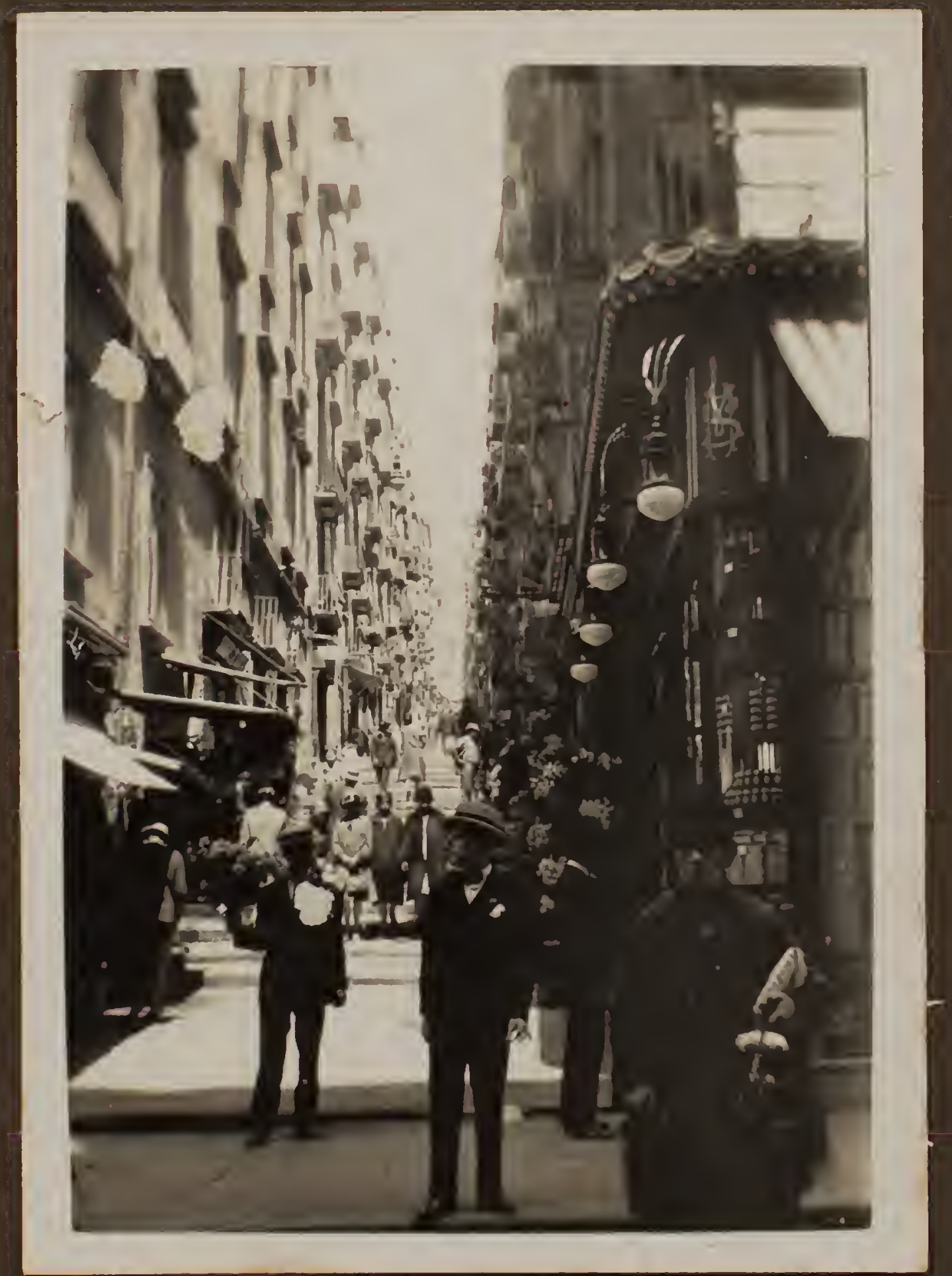

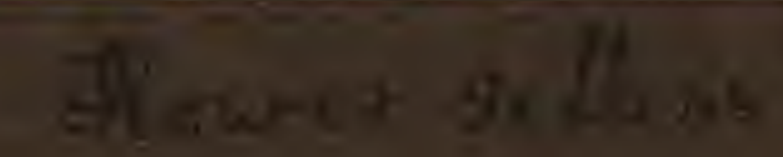



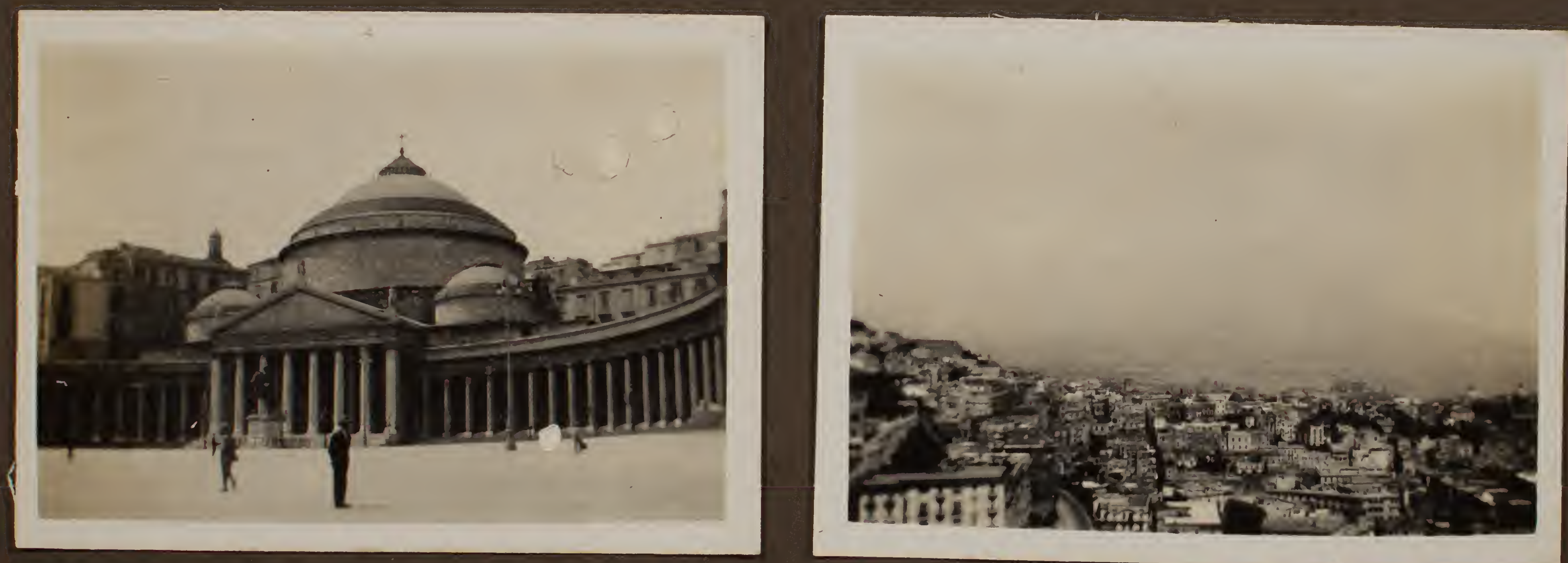

$$
\text { cothestung }
$$

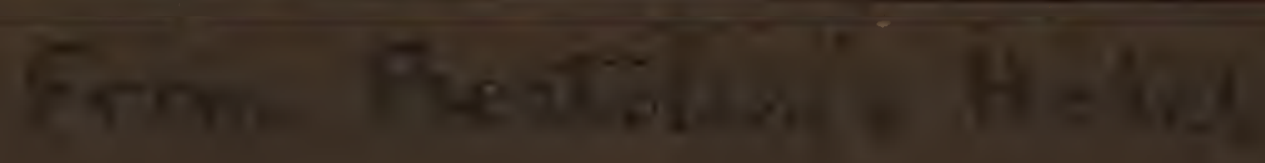

$$
\text { Noples } 3 \text { on } 28
$$




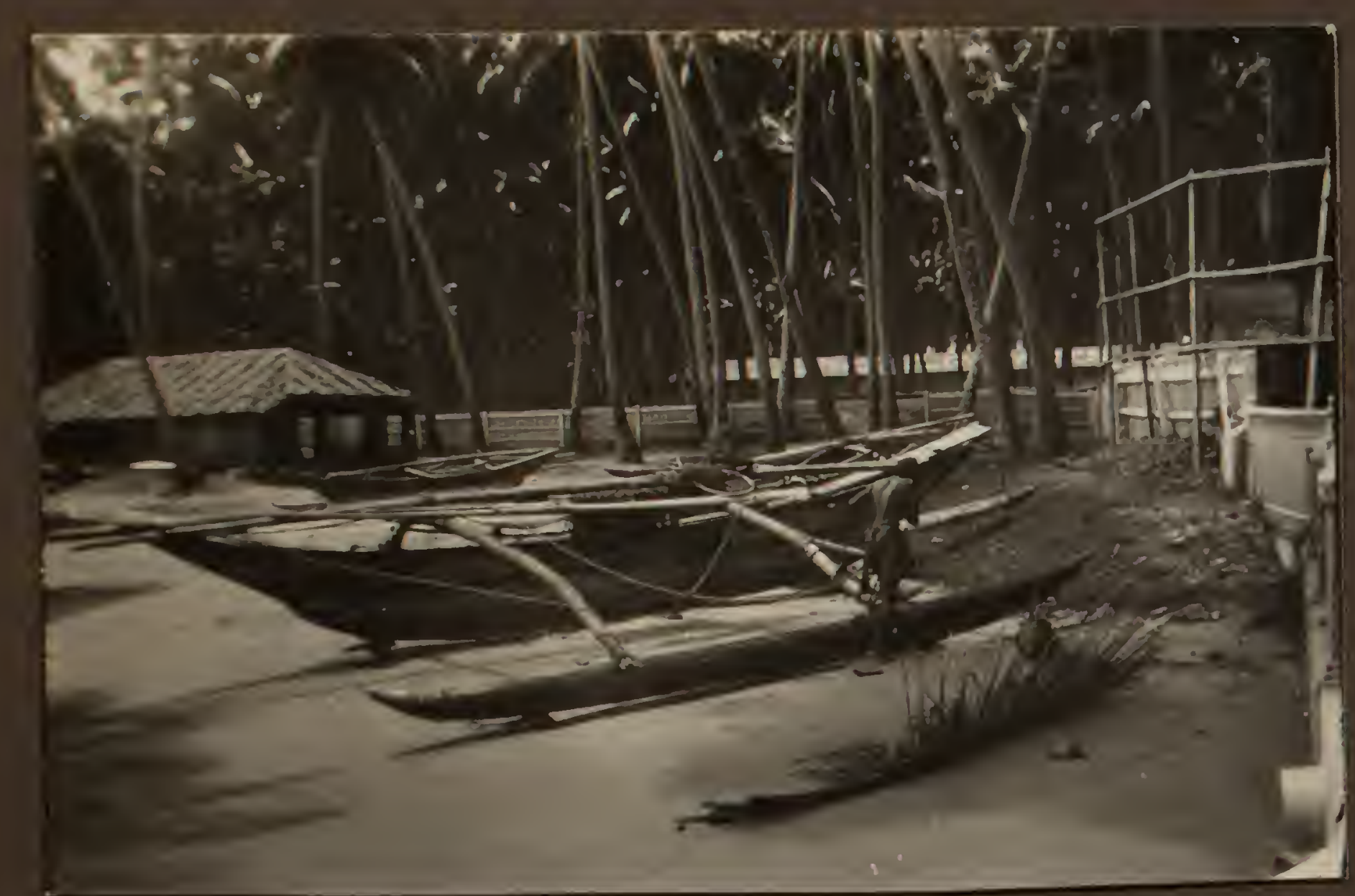

Catapanosing

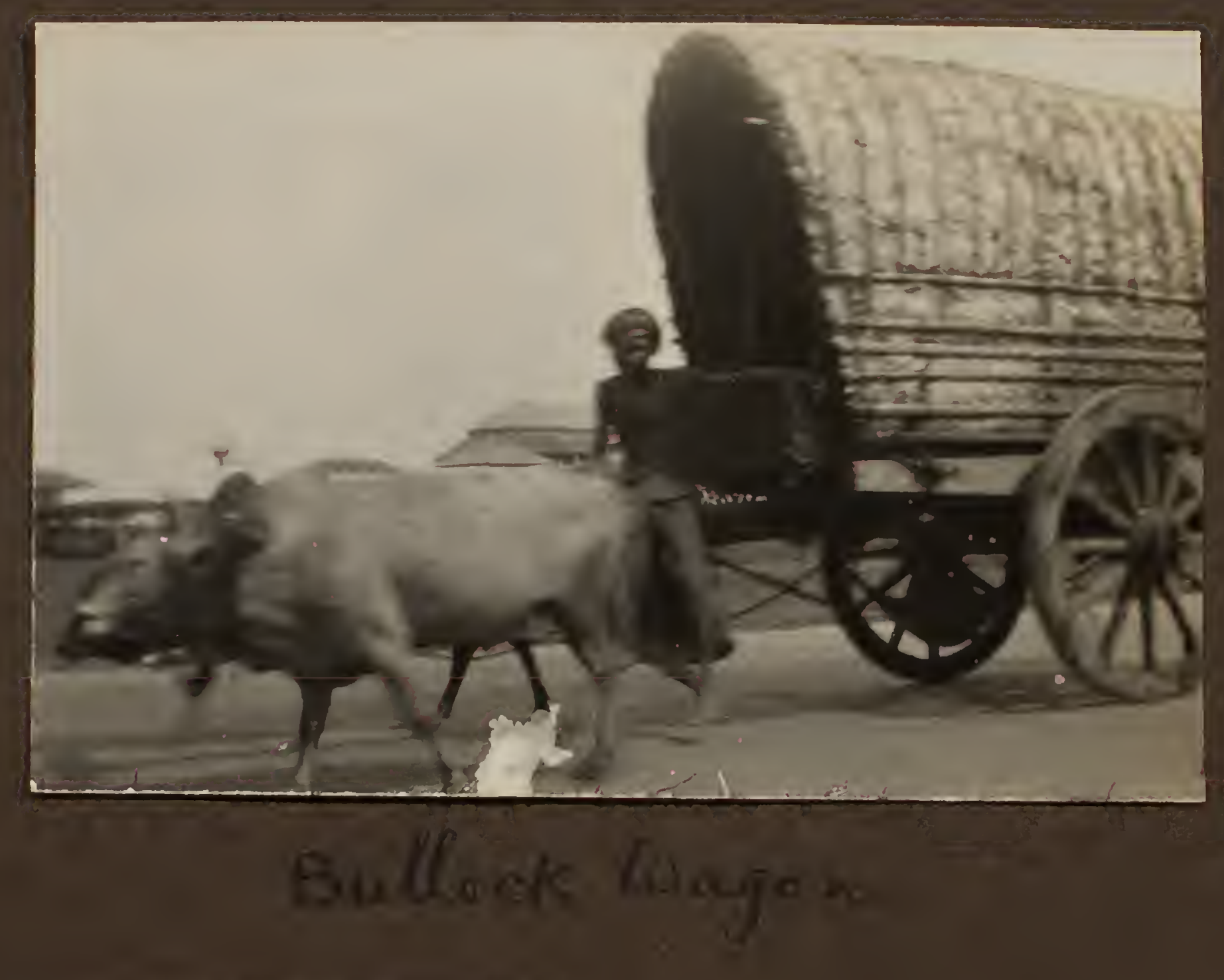

colomito

$16 \times 1.28$

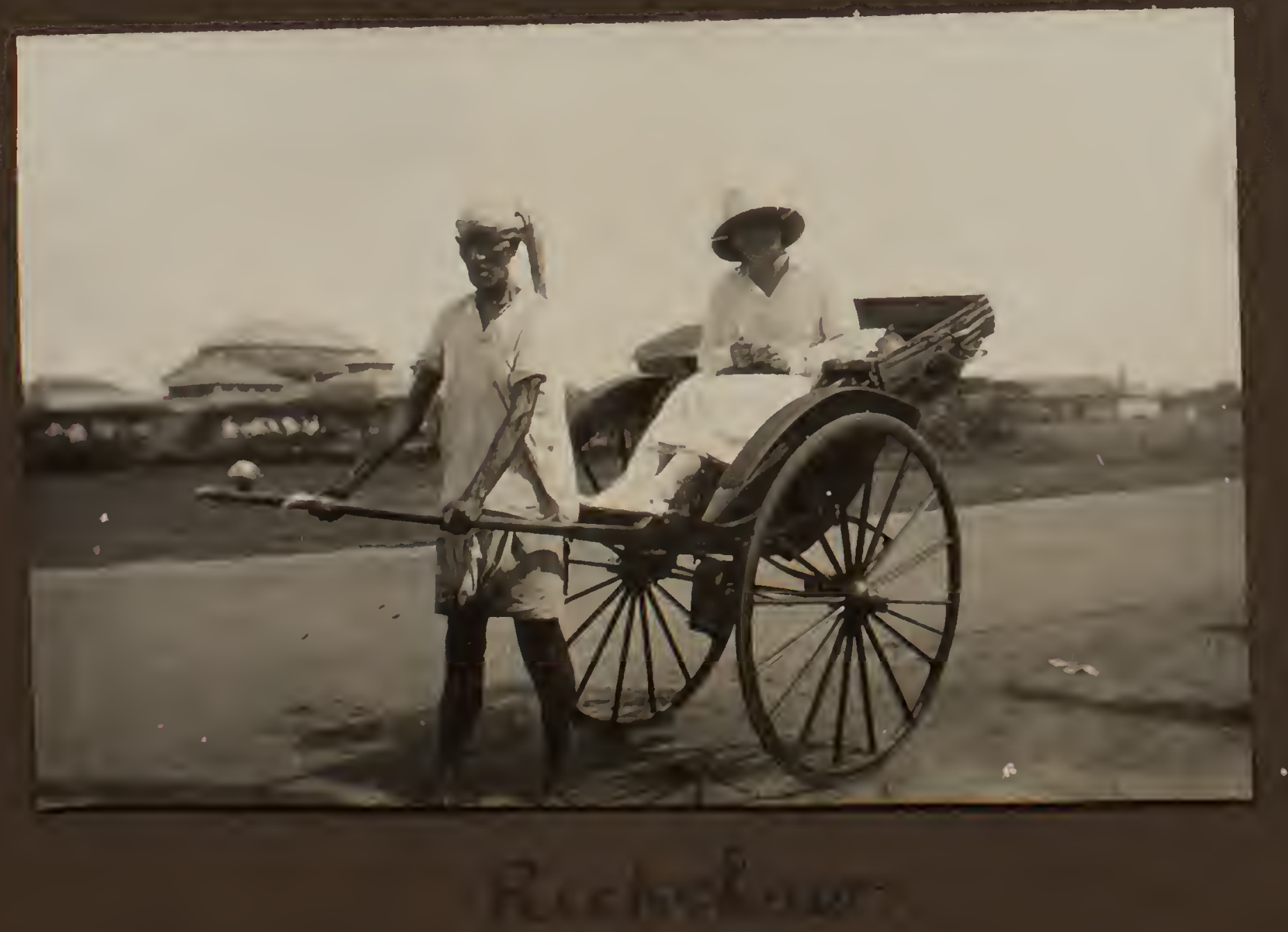



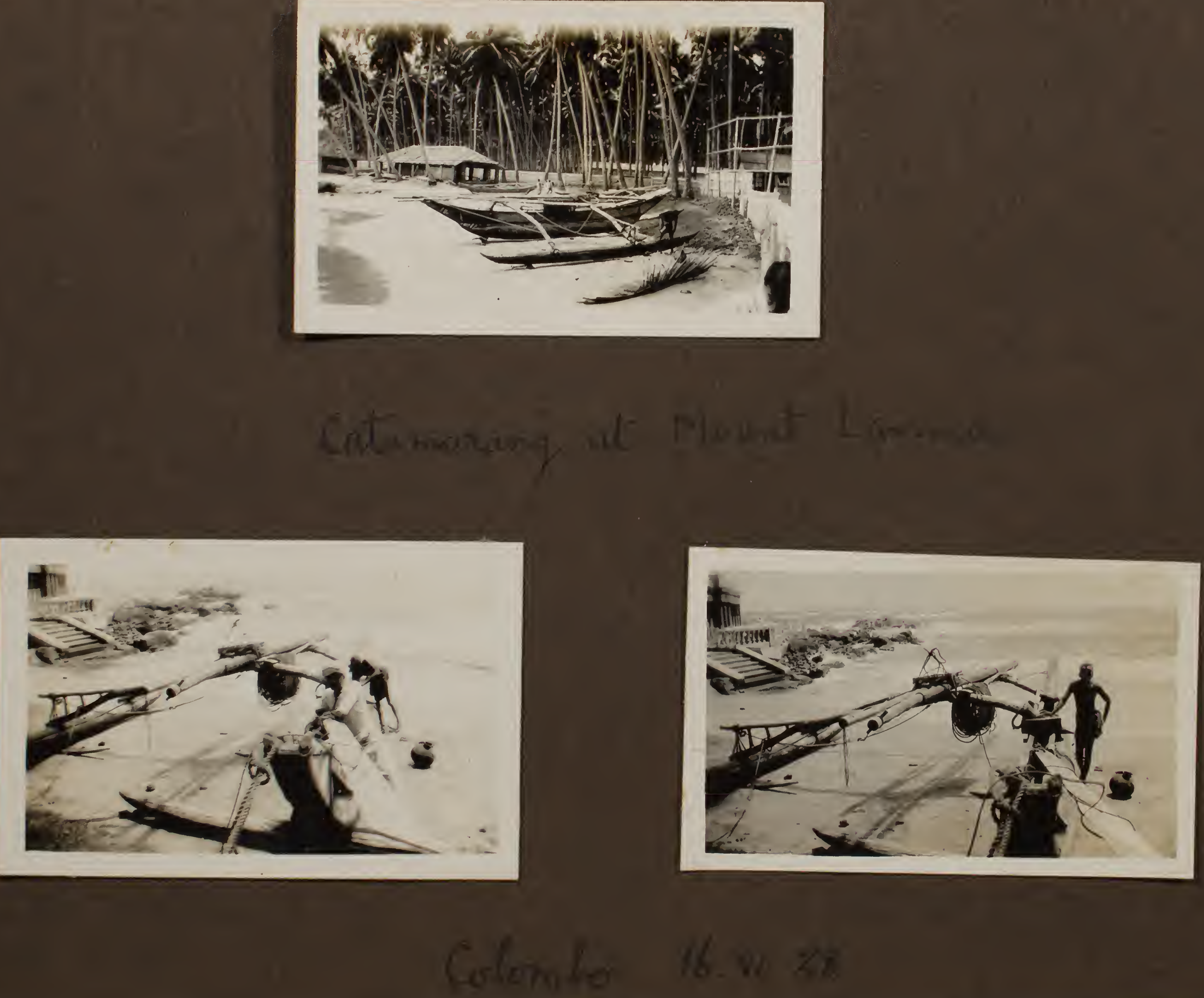

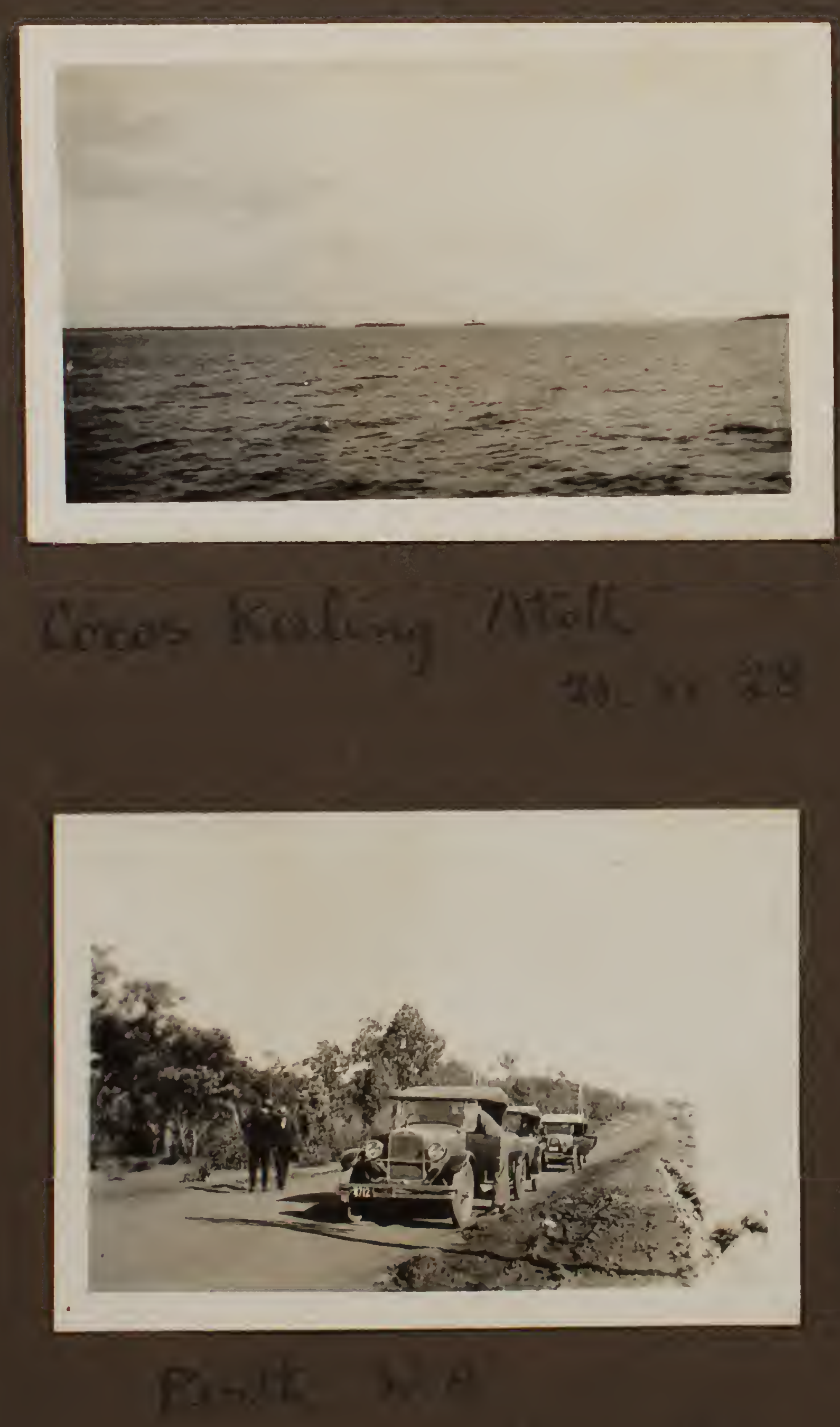

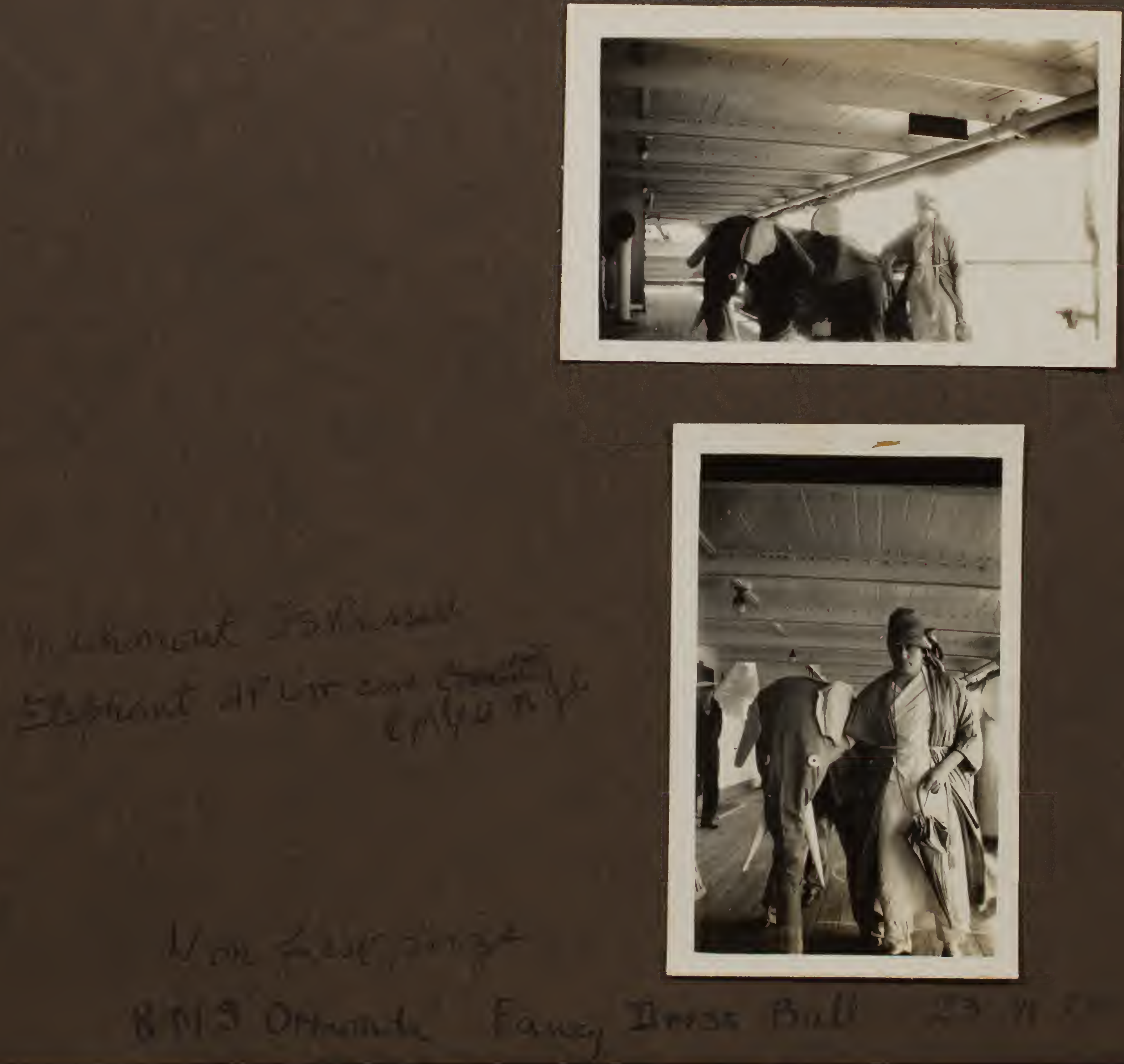

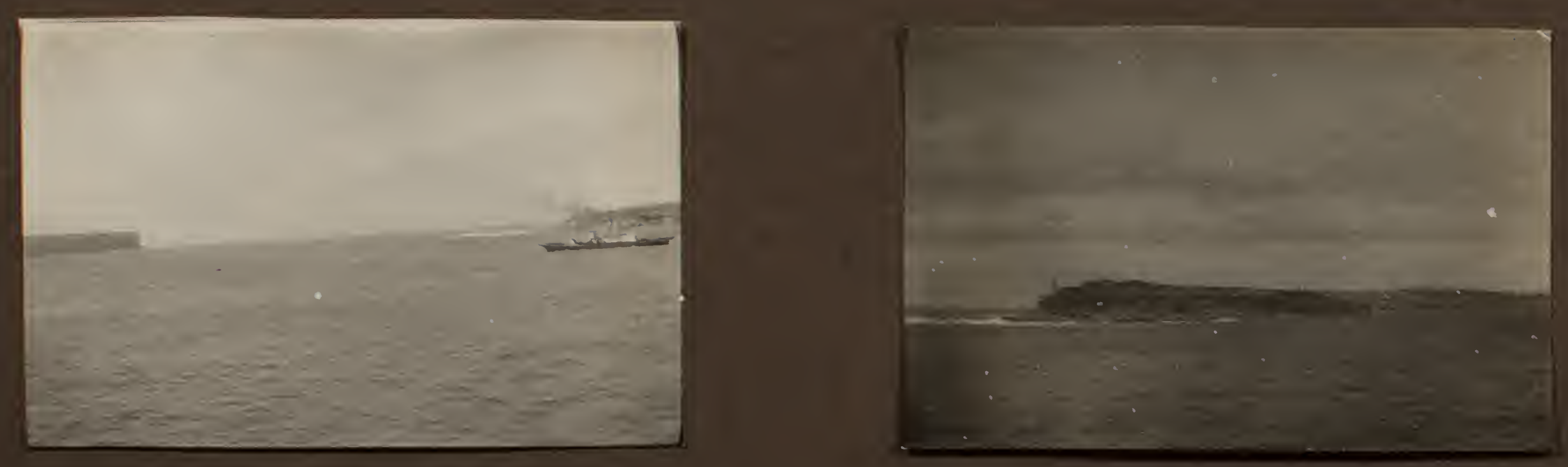

Sydincy thadis 5 wa 28
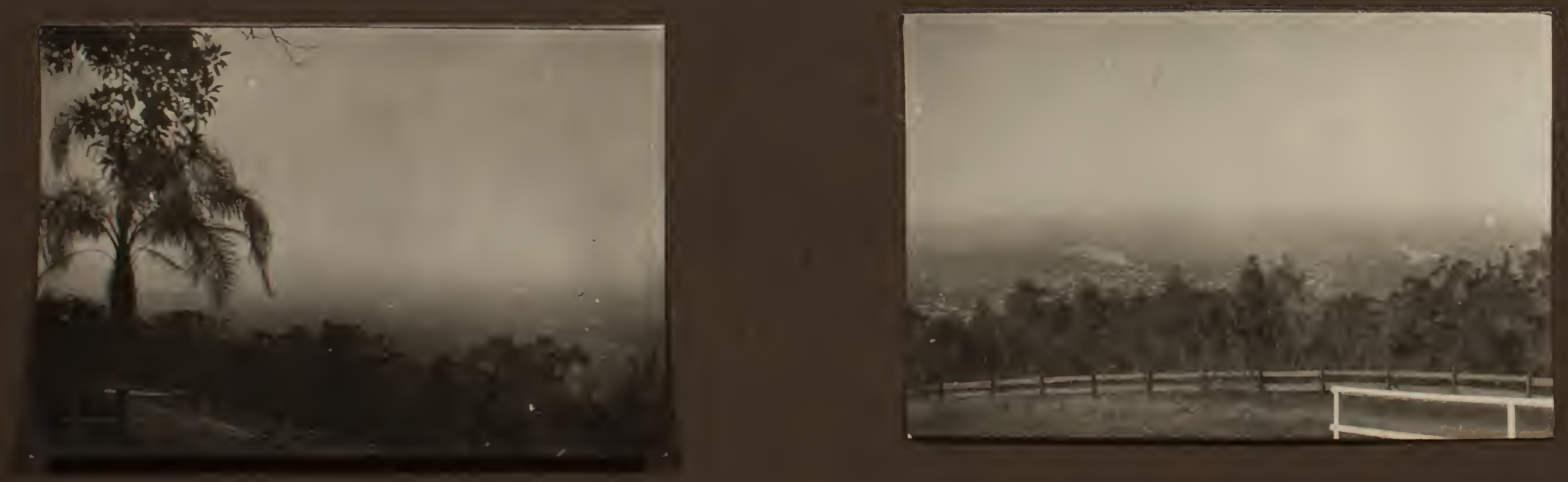

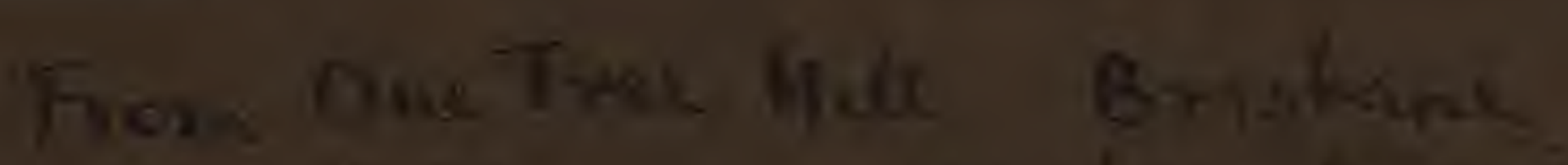

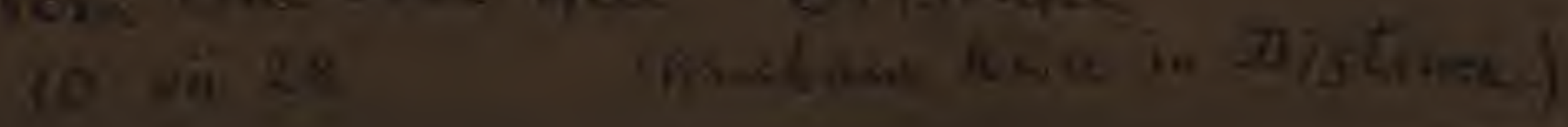



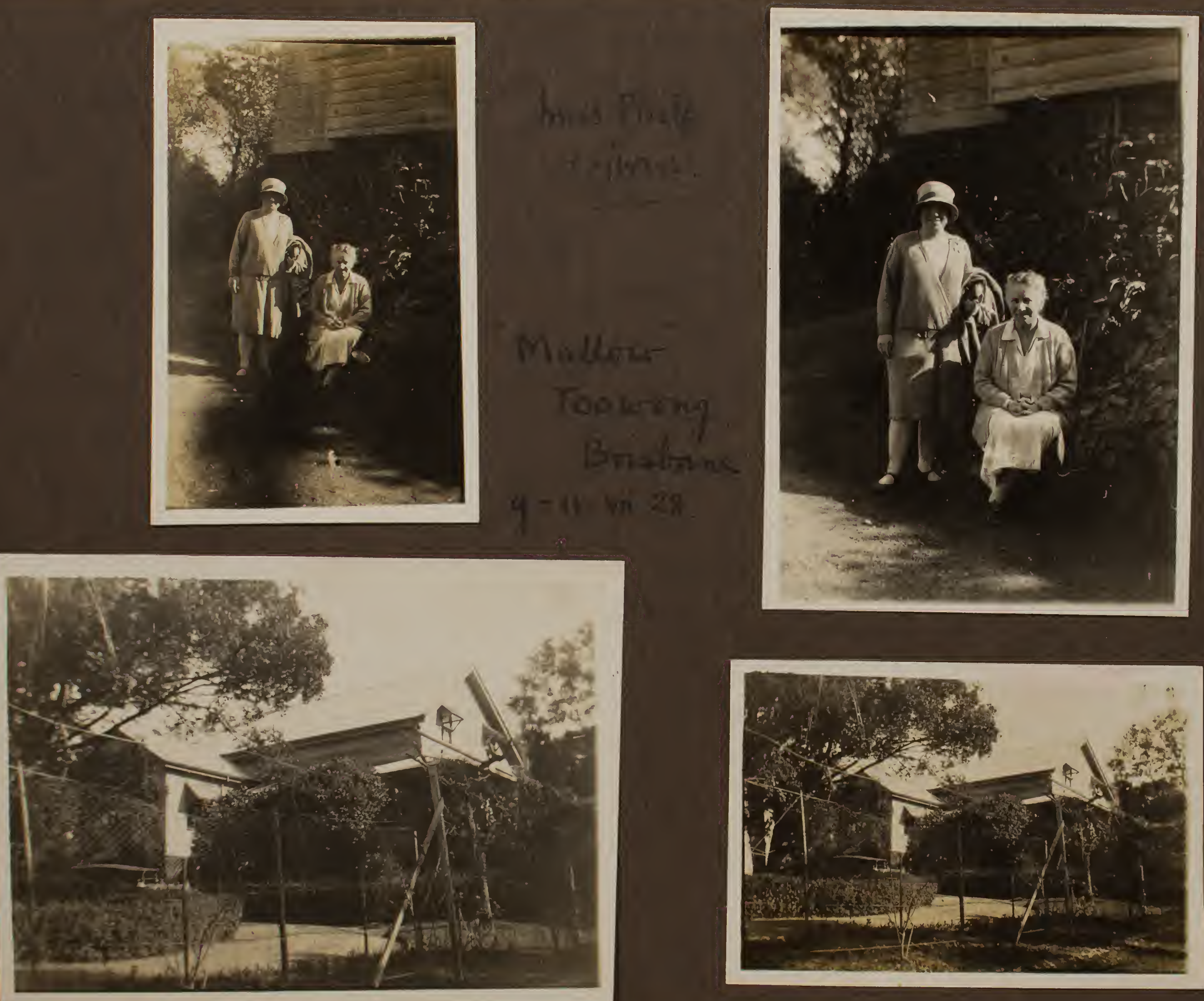


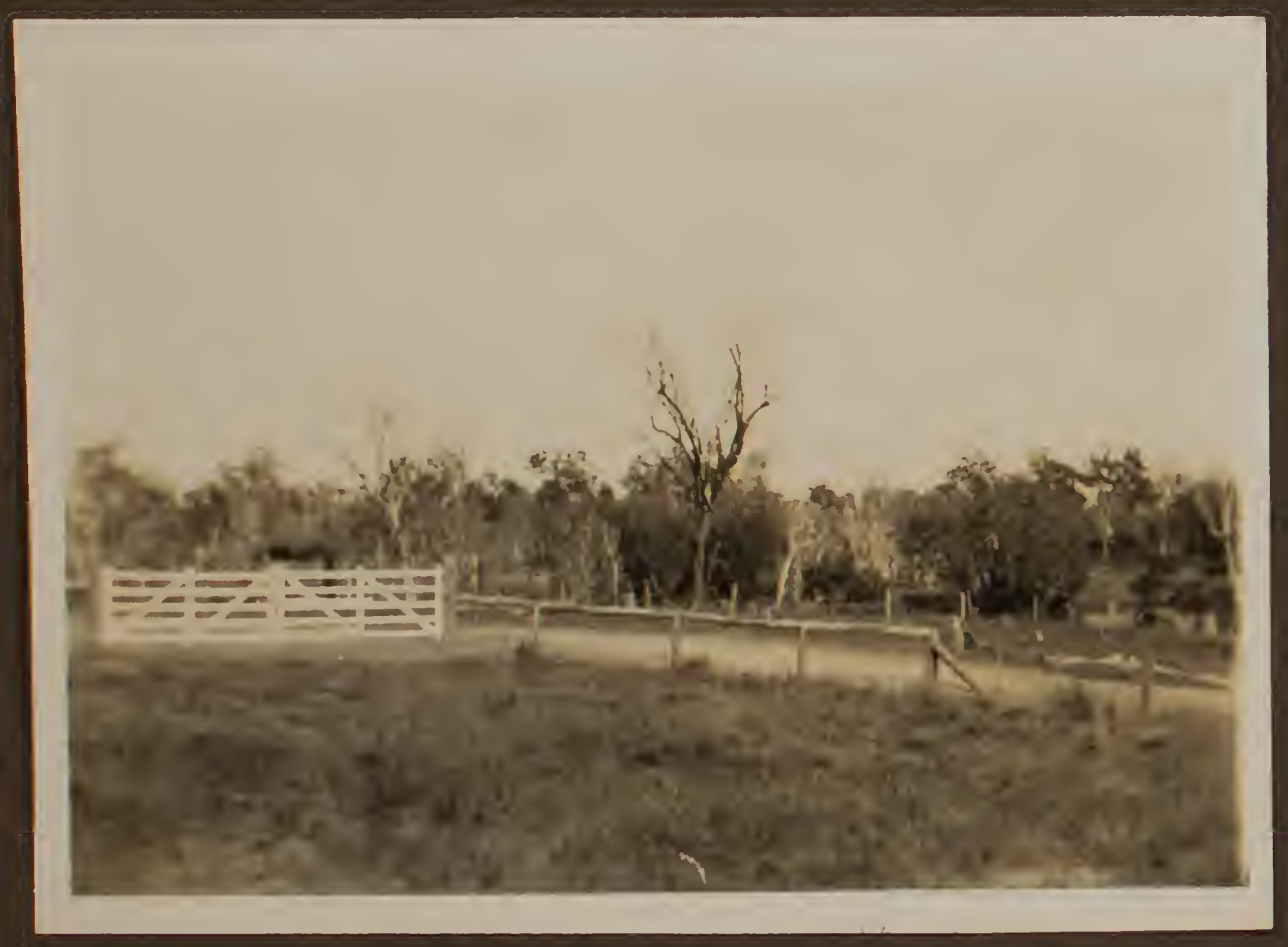

$$
\begin{aligned}
& \text { Ereane Tramat. }
\end{aligned}
$$

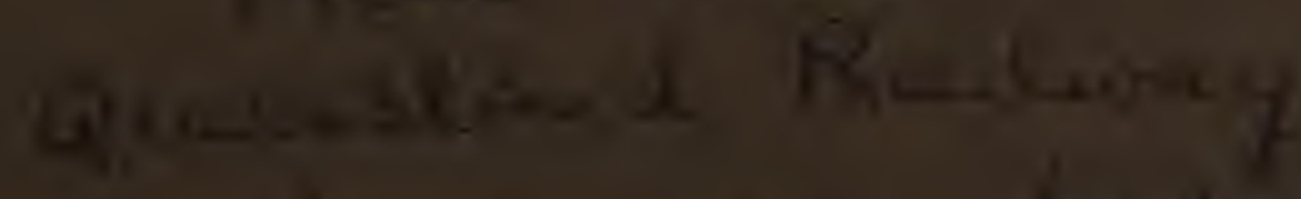

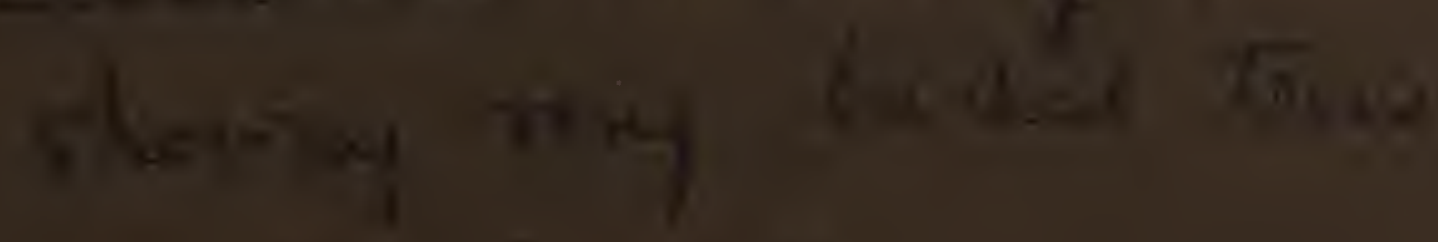

$$
\begin{aligned}
& 13 \text { vis } \times 8
\end{aligned}
$$

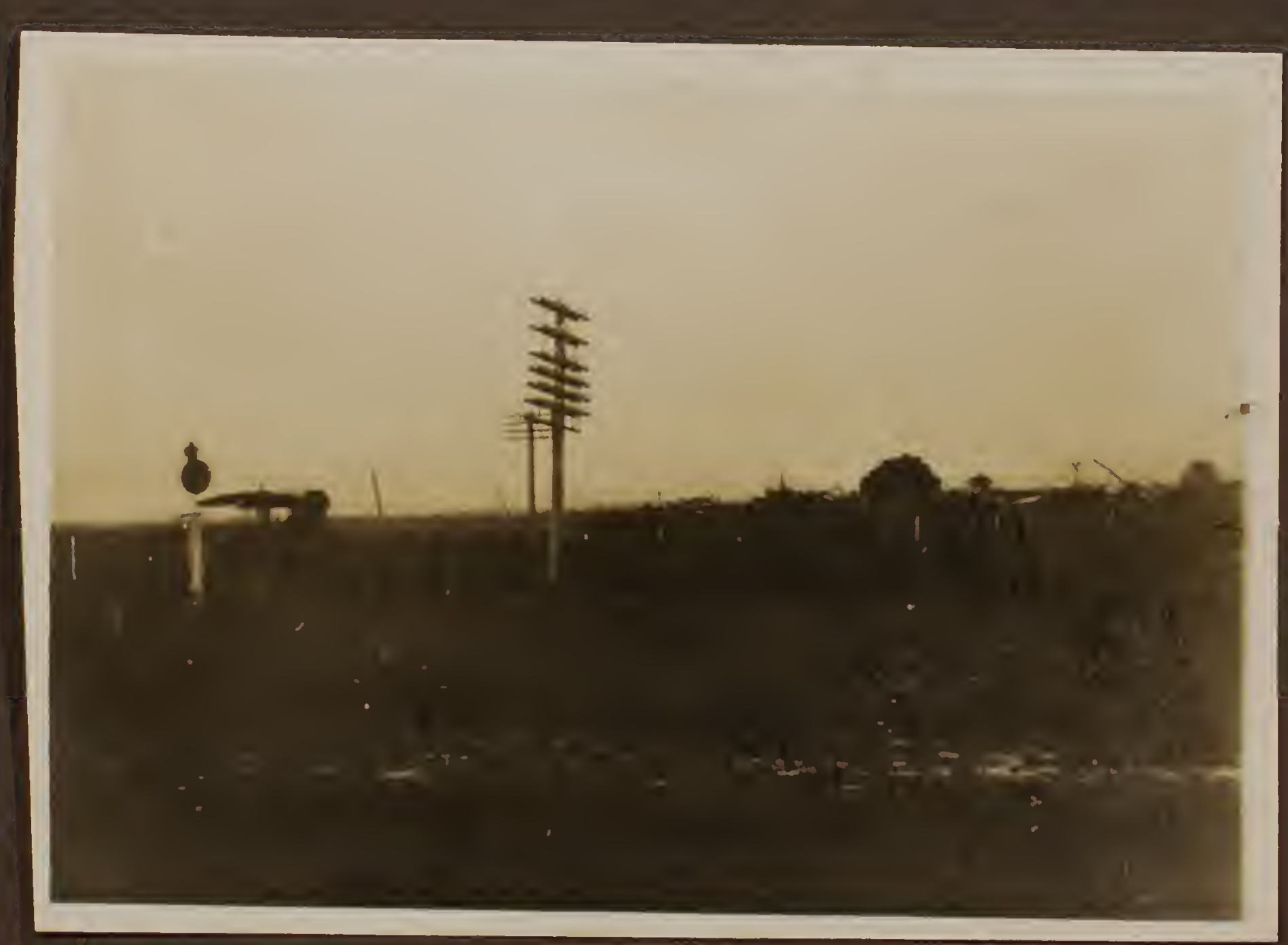

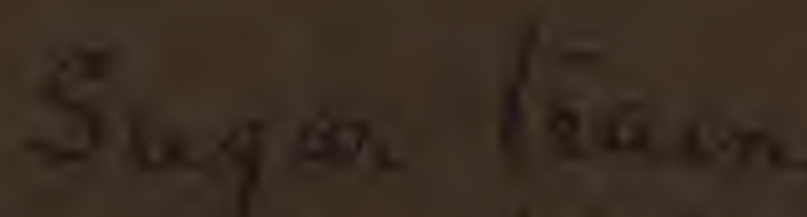

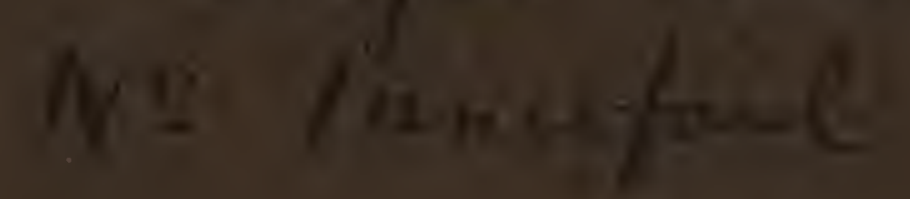

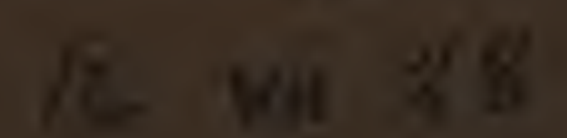



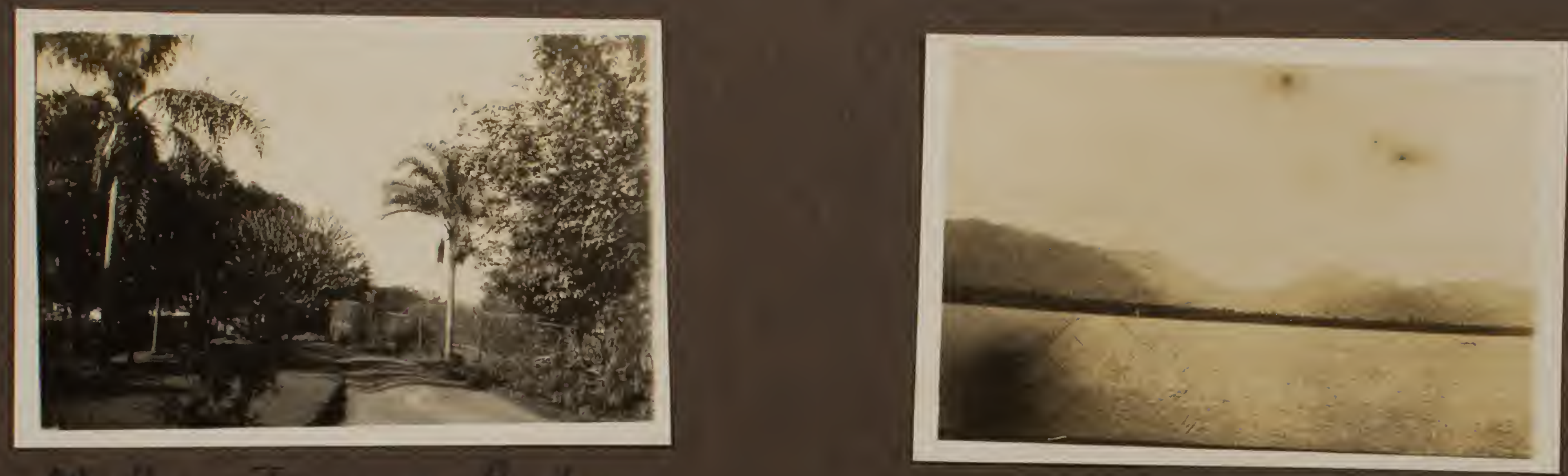

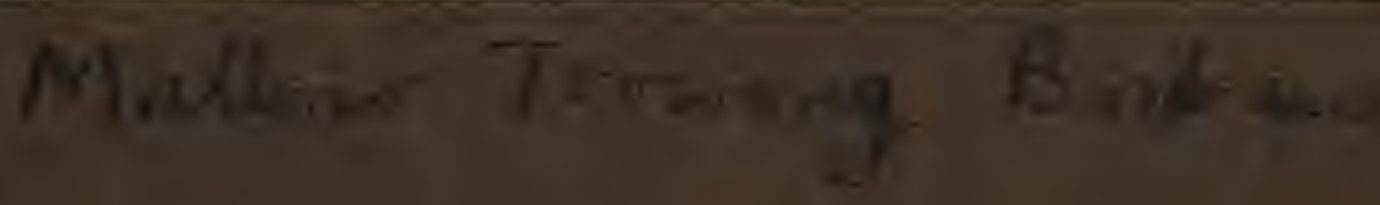
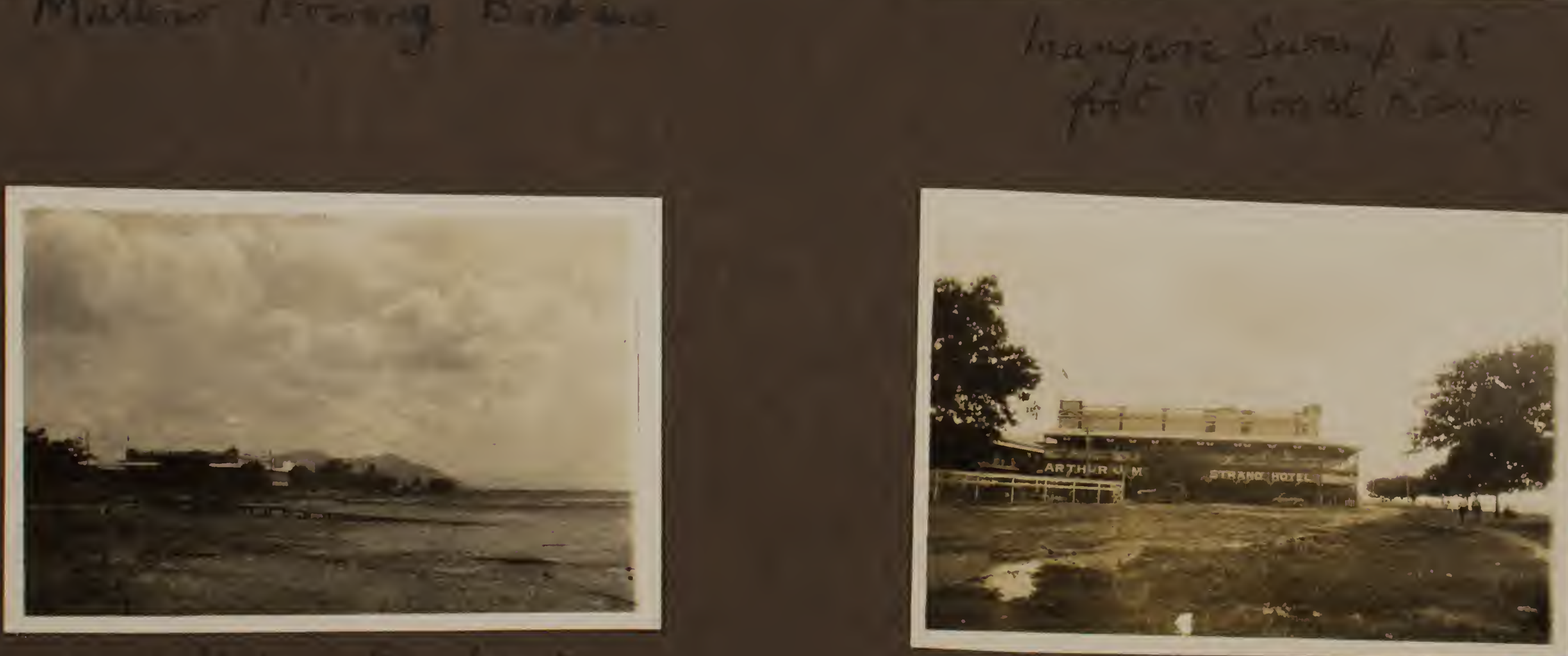

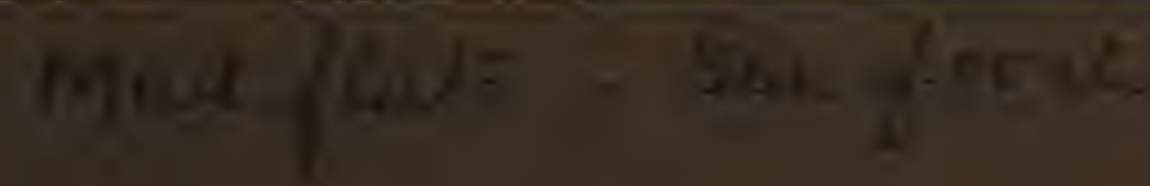

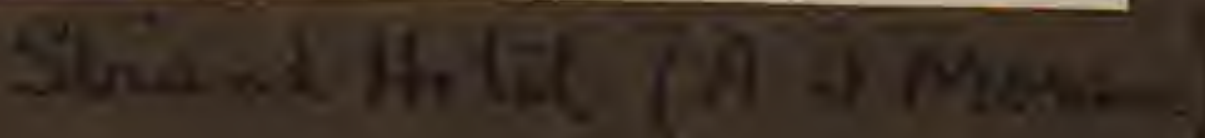

Cavios 14-15, hi 23 

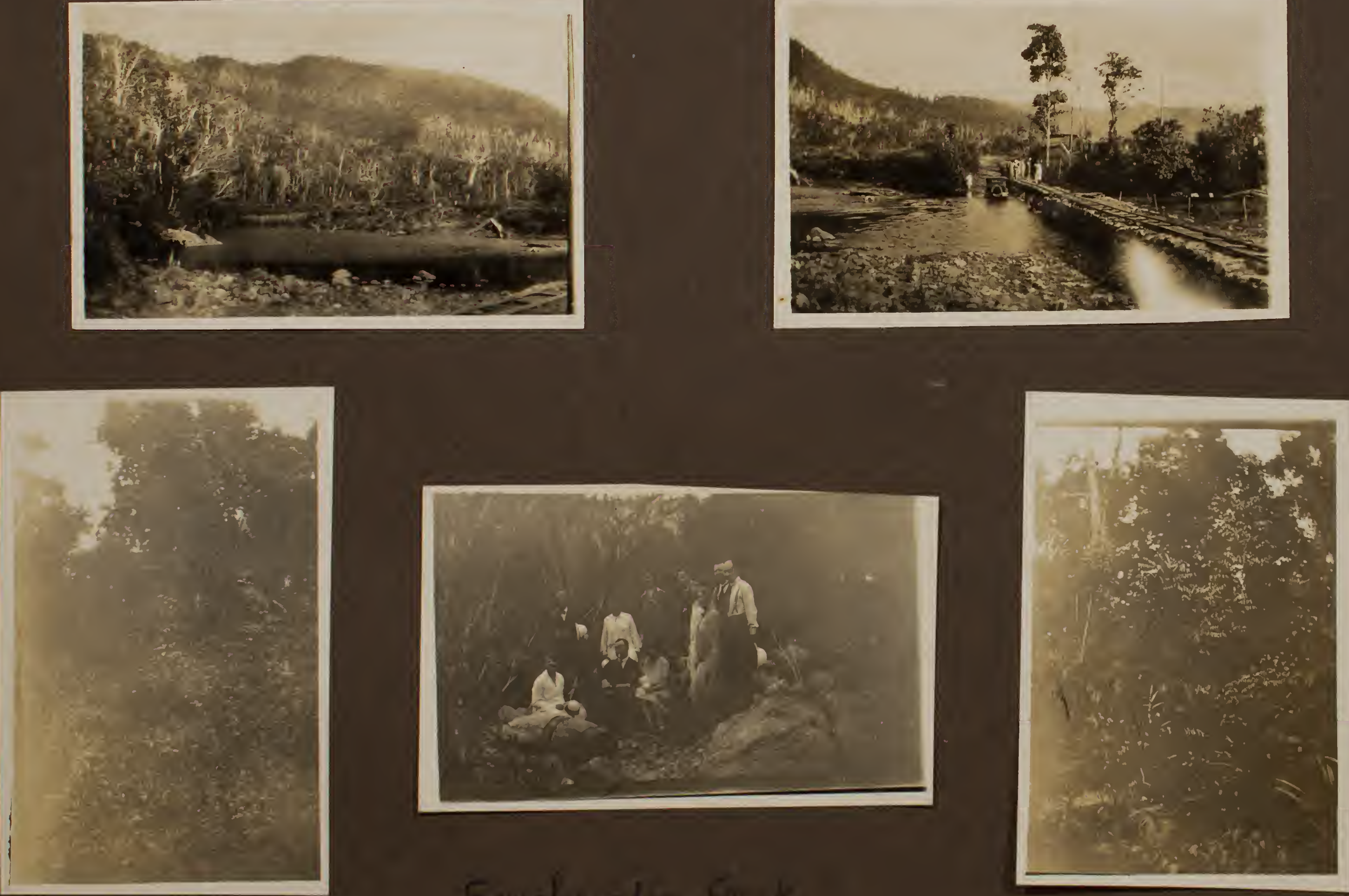

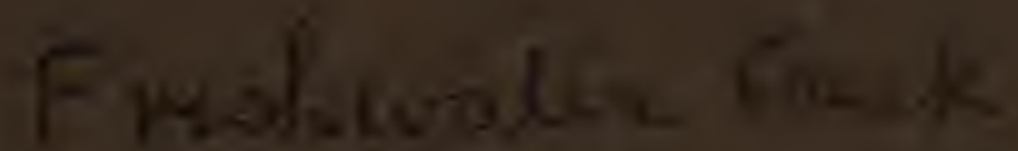
Noar Cothre $15 \mathrm{kn} 2 \mathrm{~s}$ 

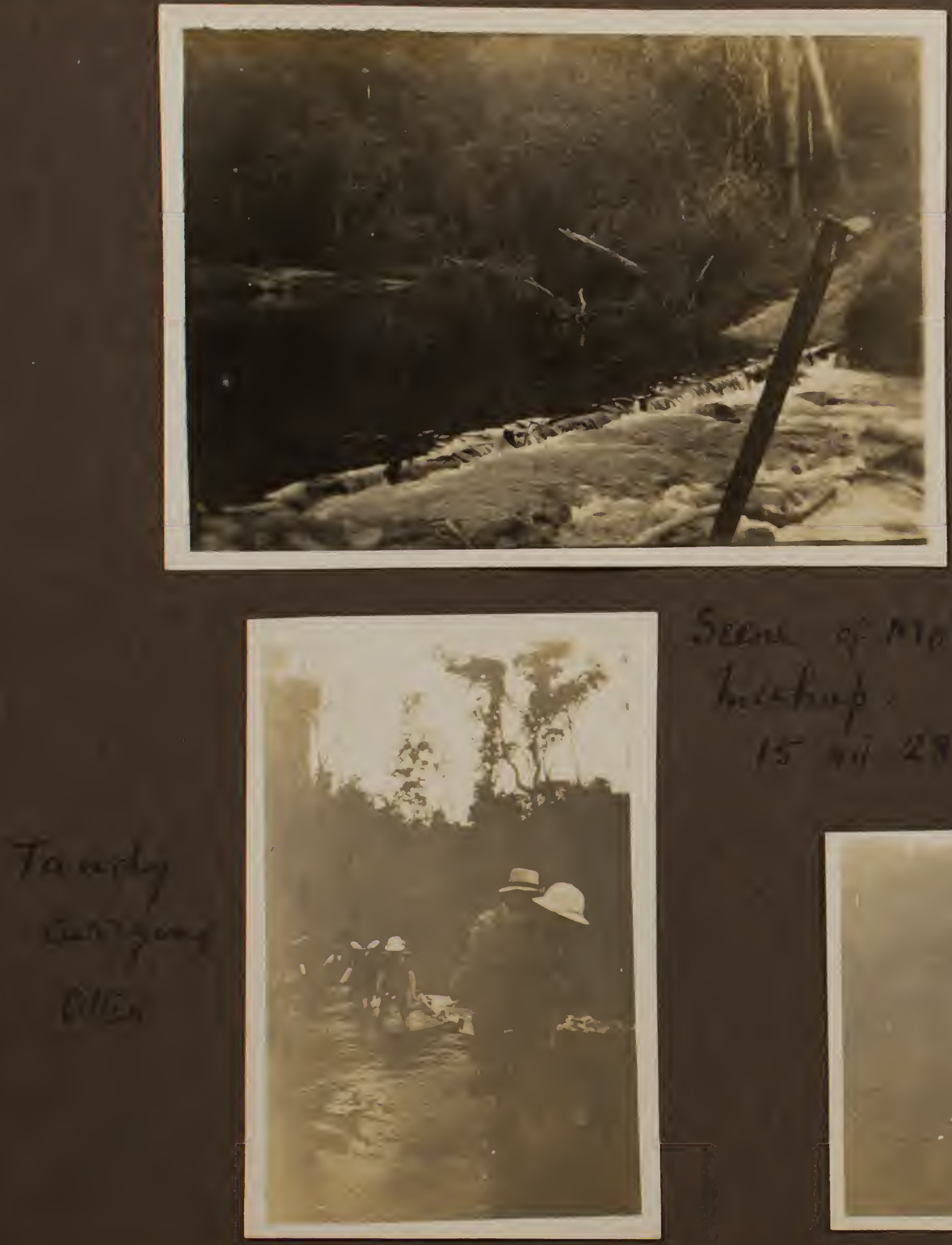

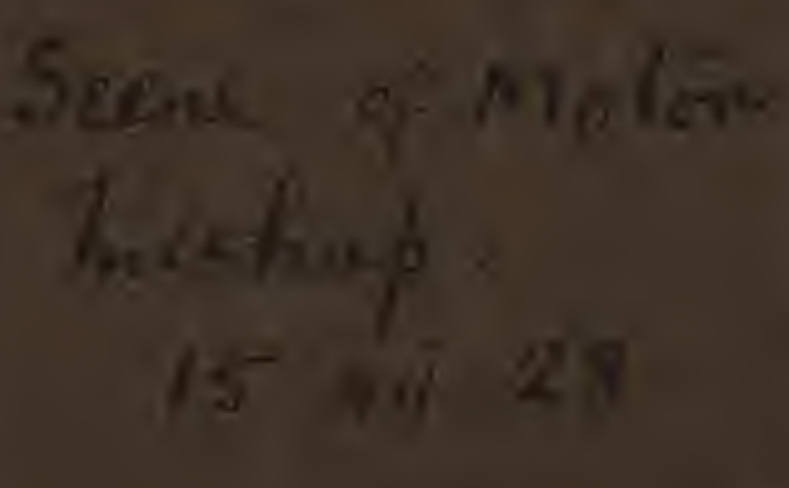
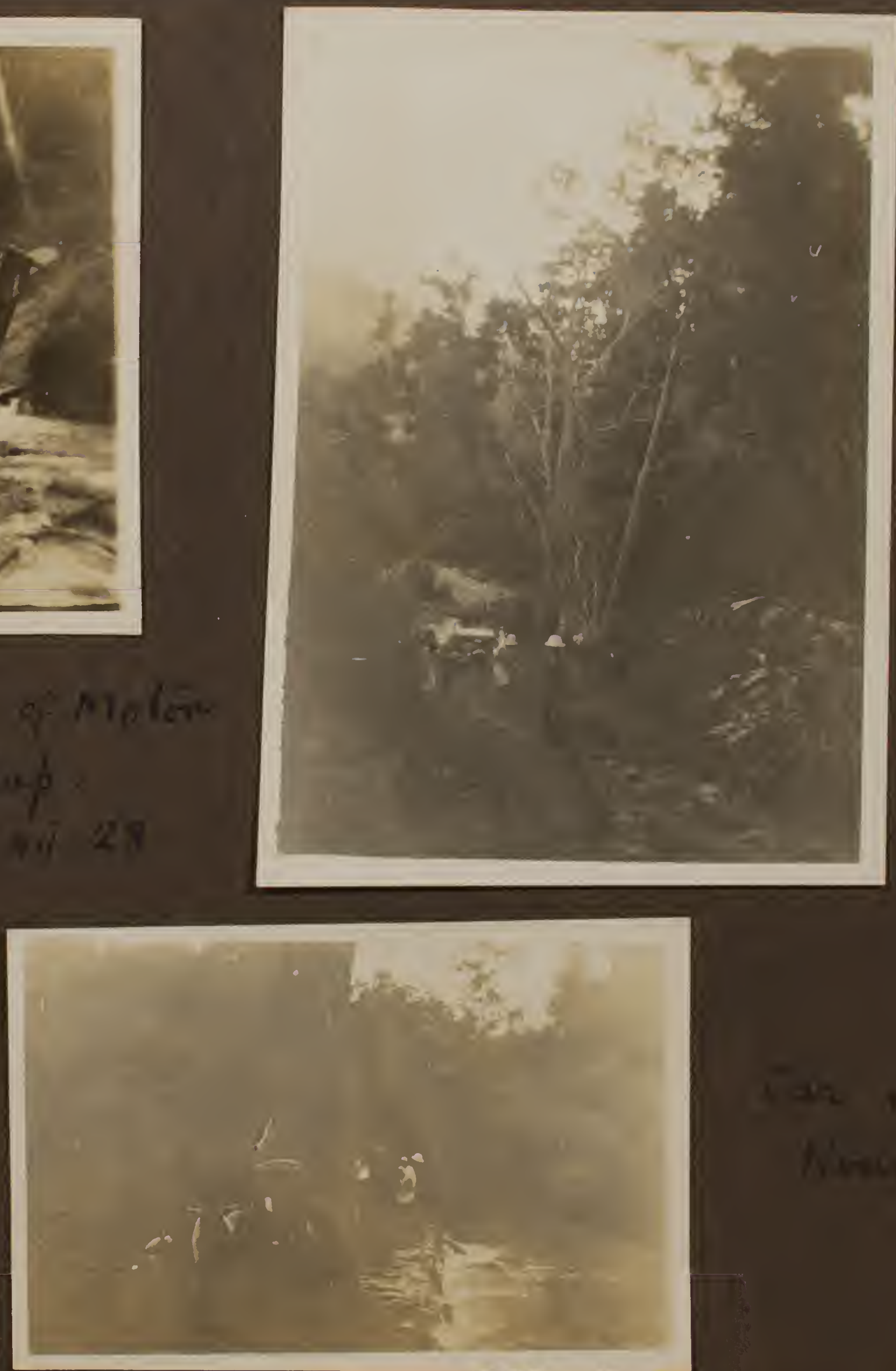

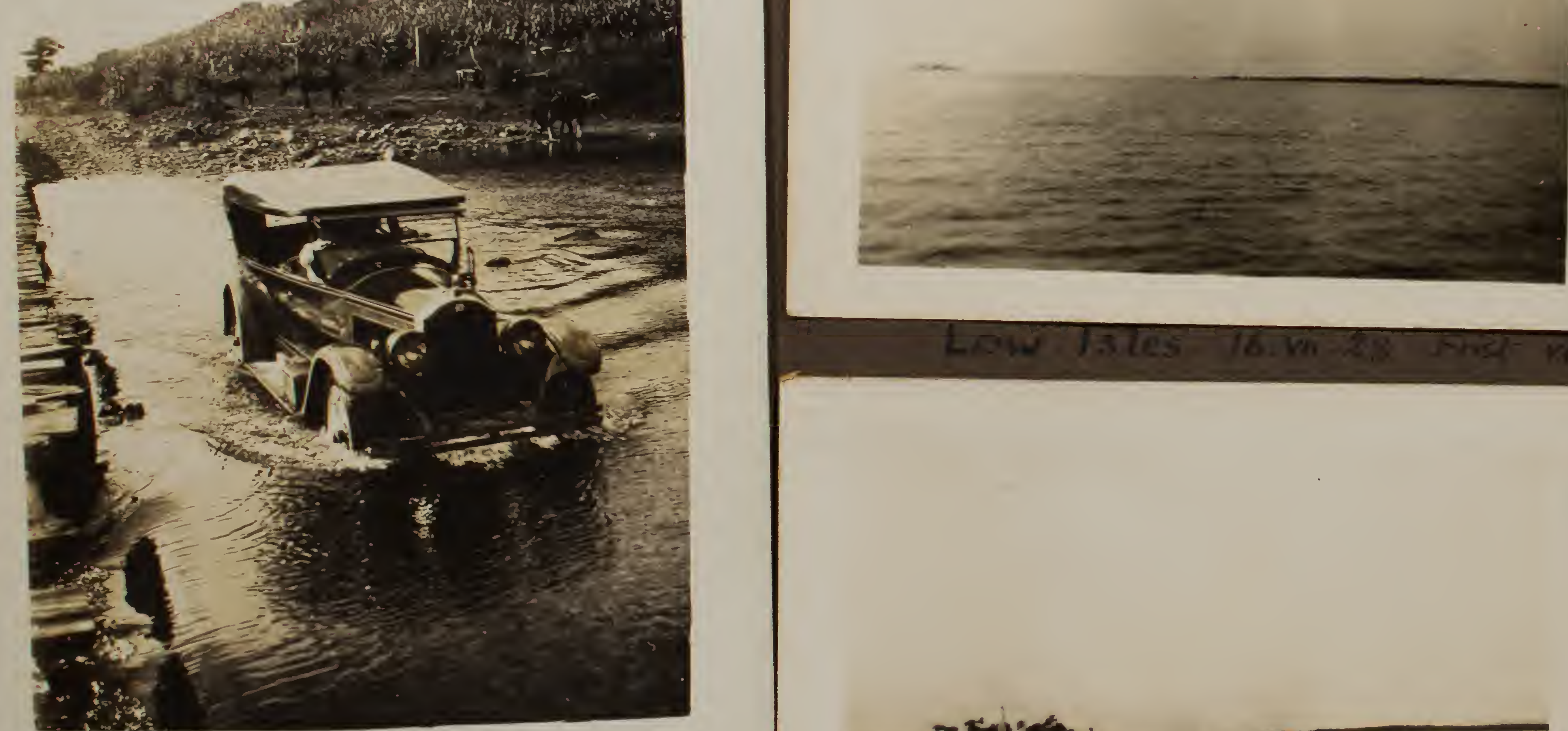

16. Wh

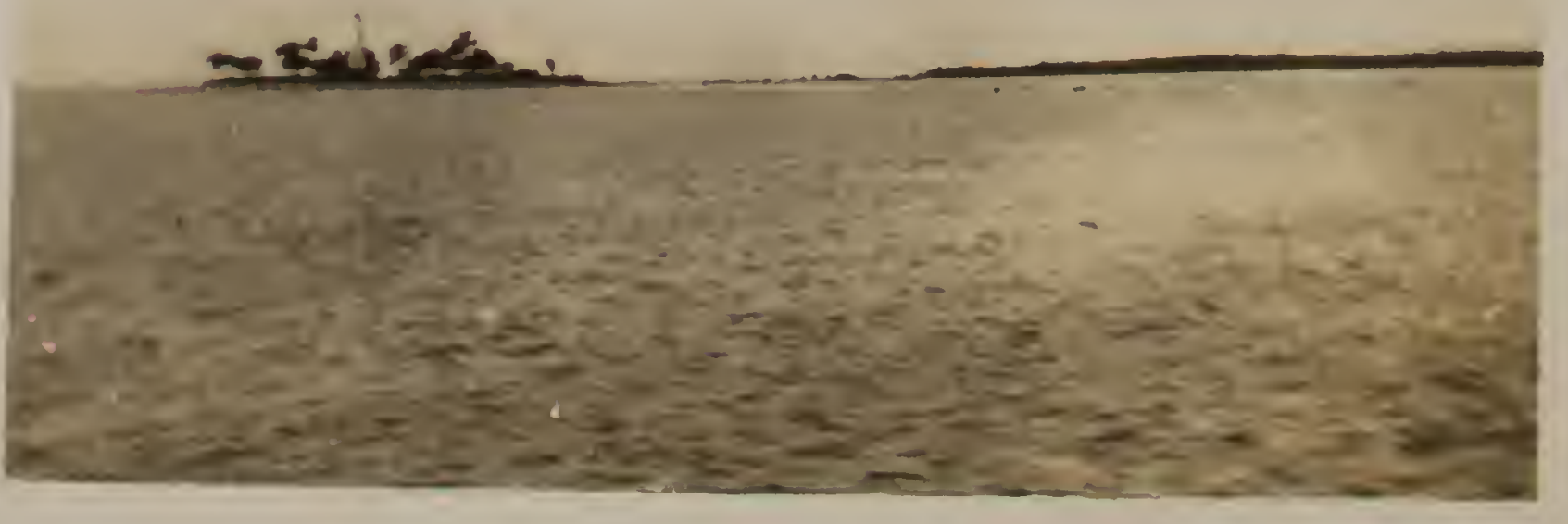



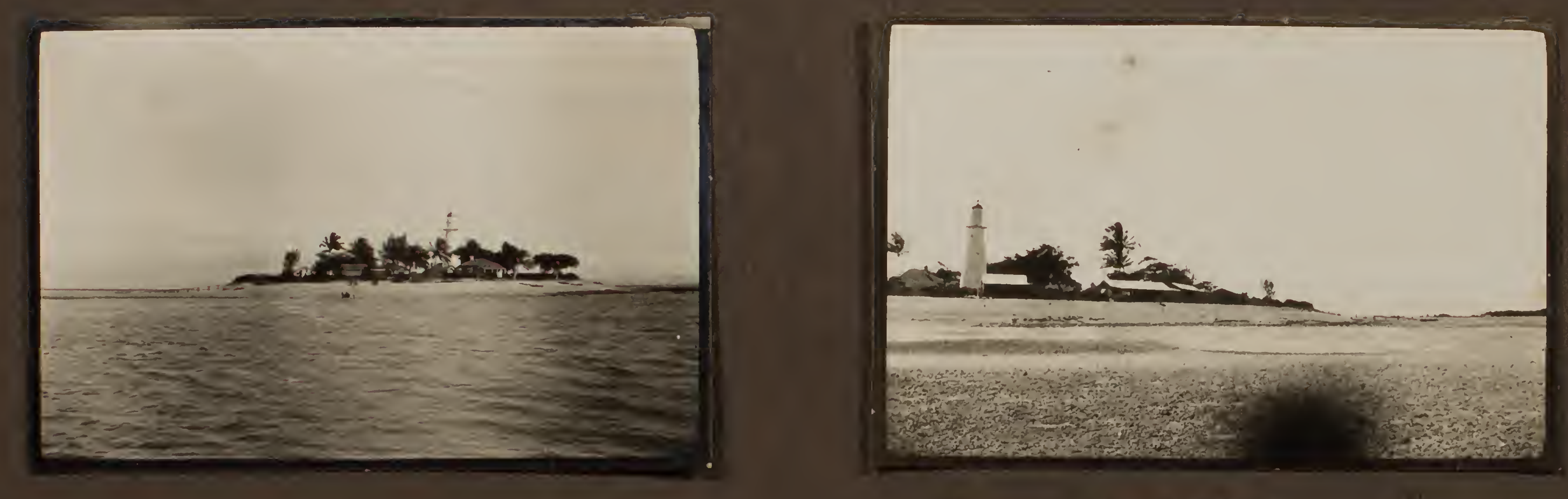

\section{Lew How then from}
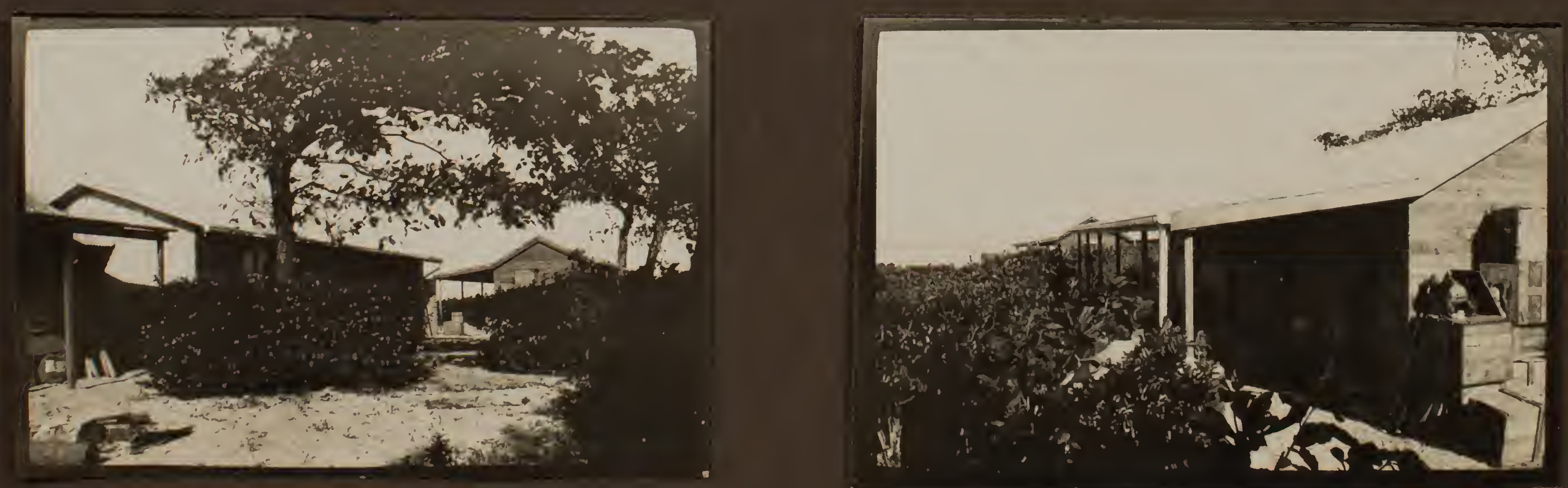


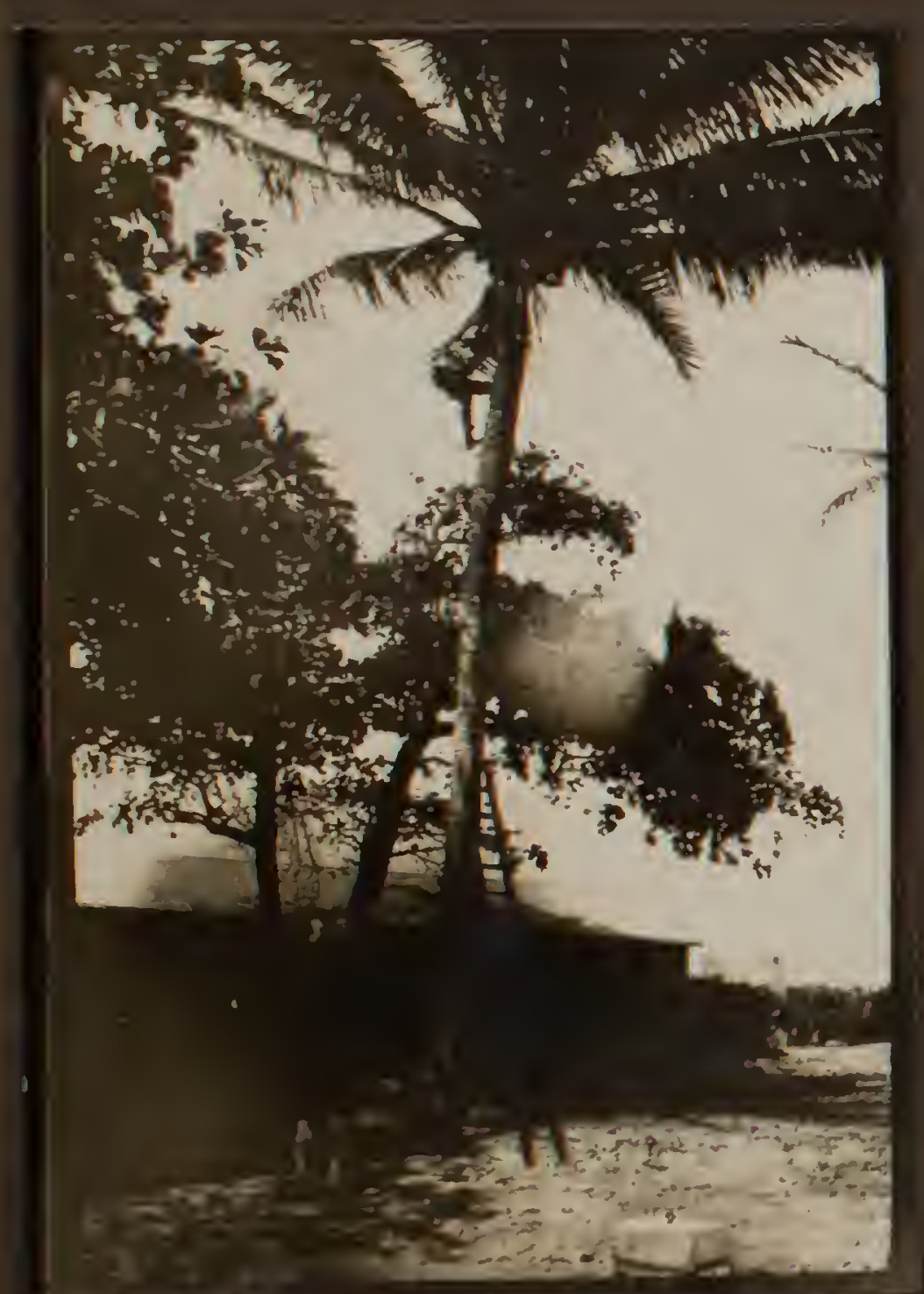

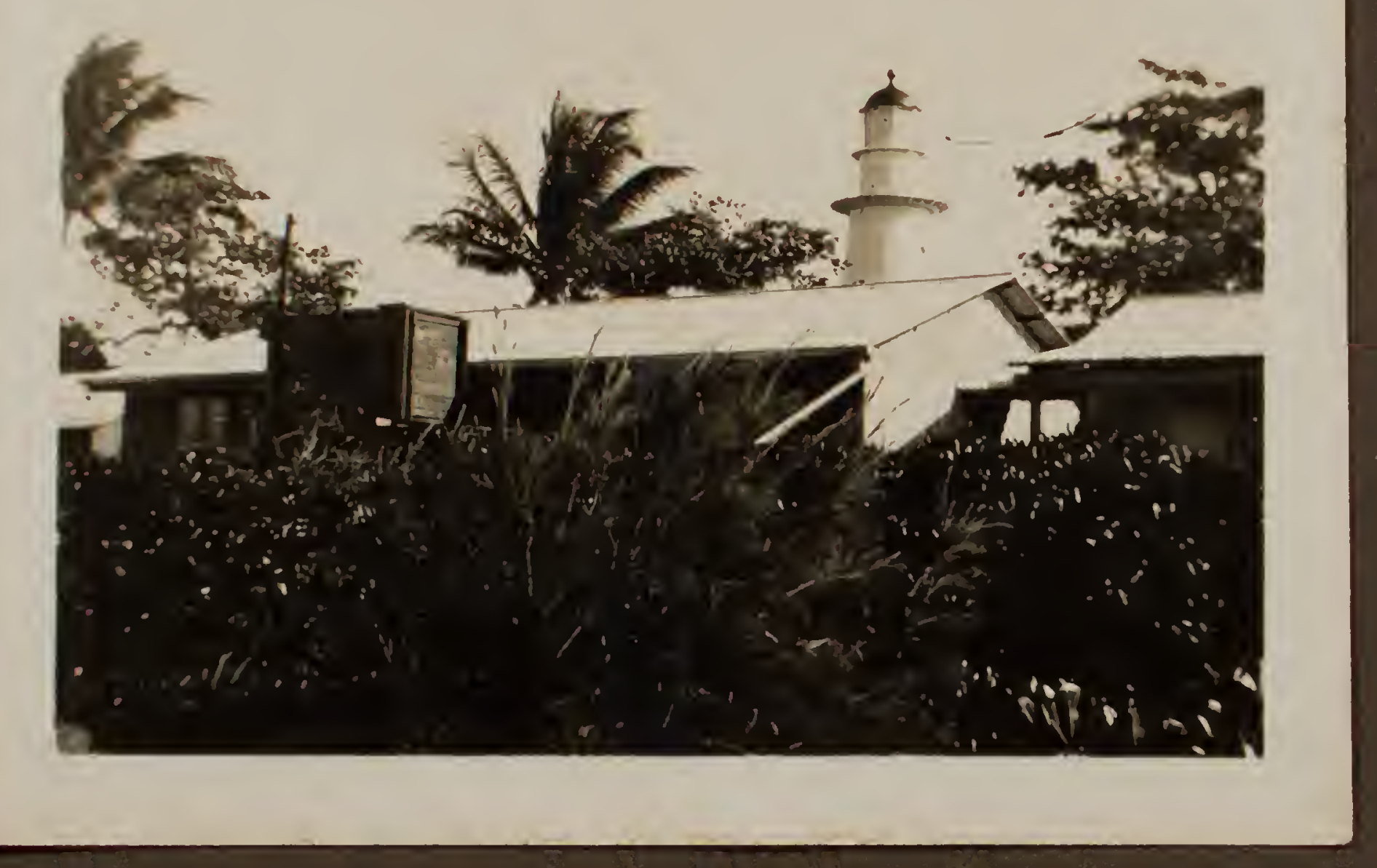

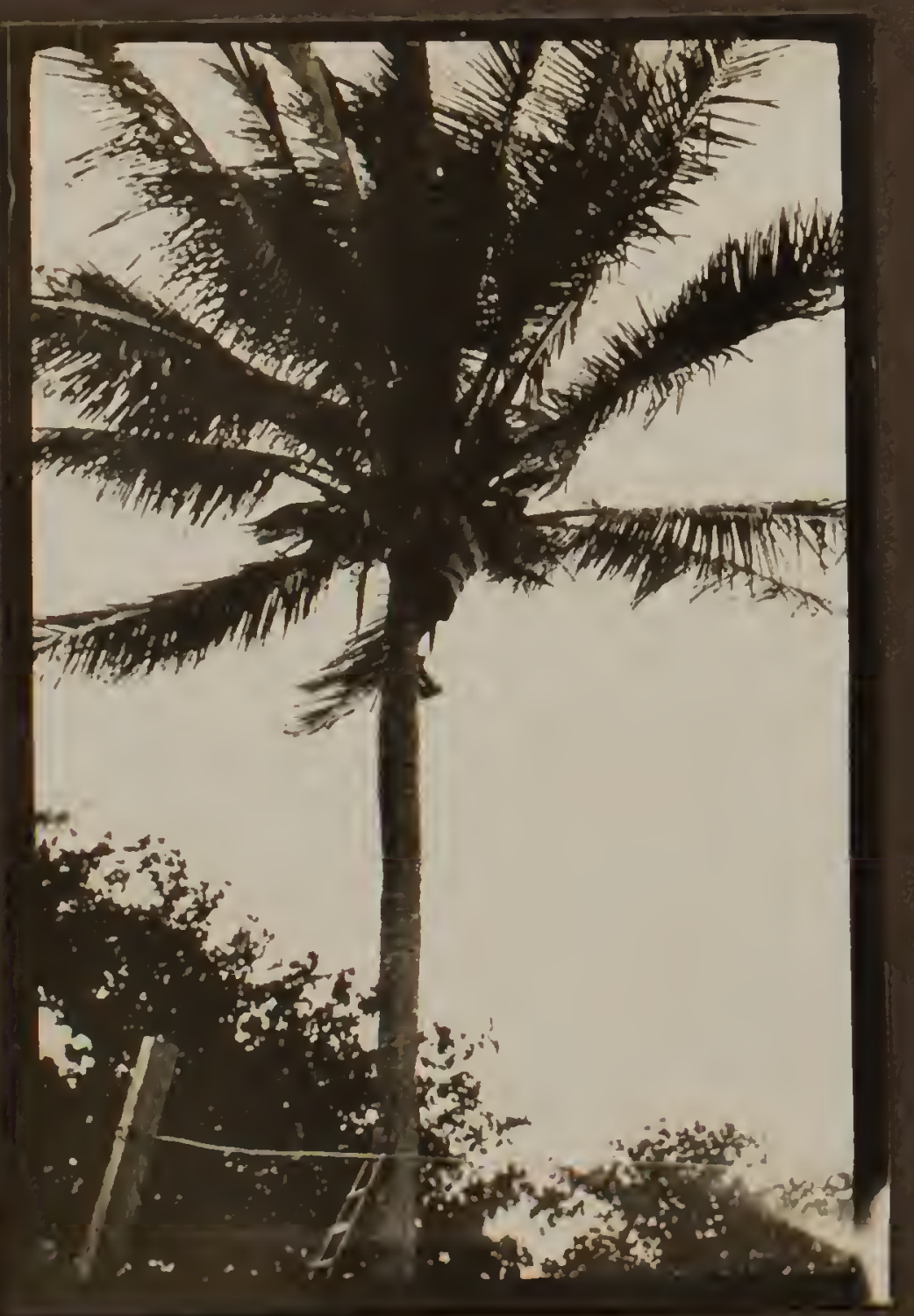

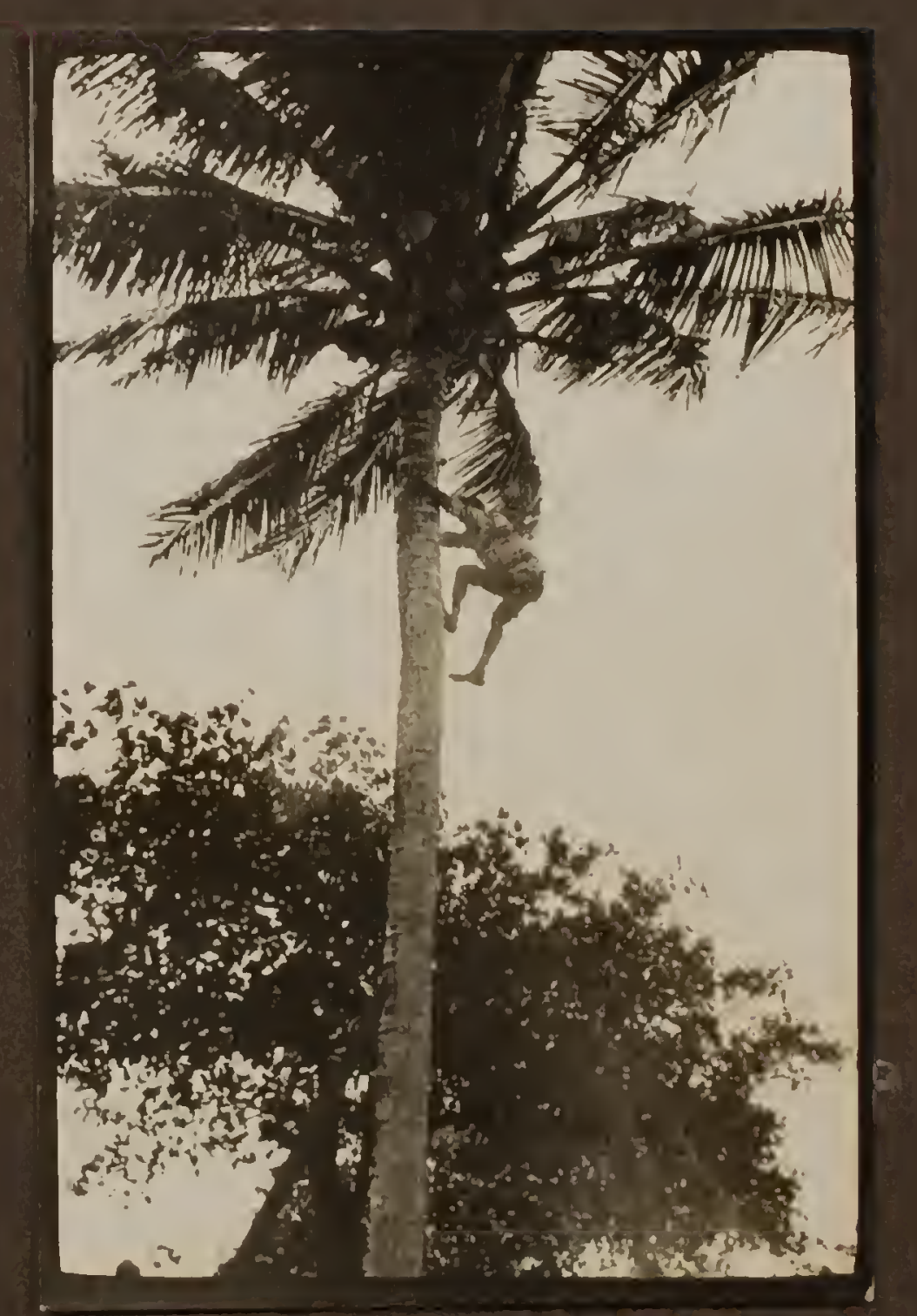

Andy up

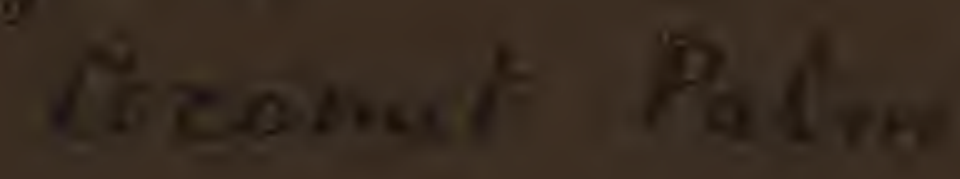



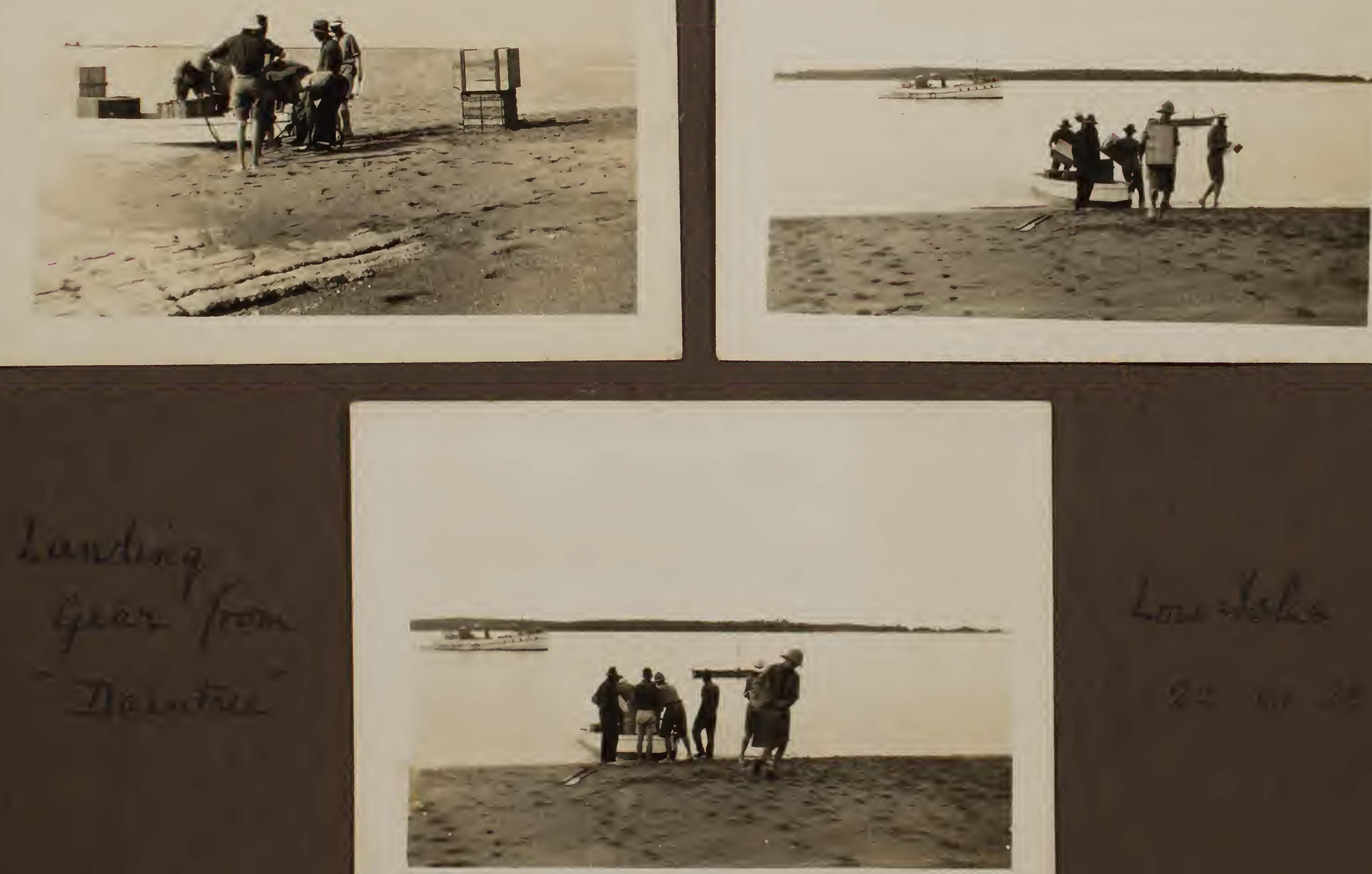

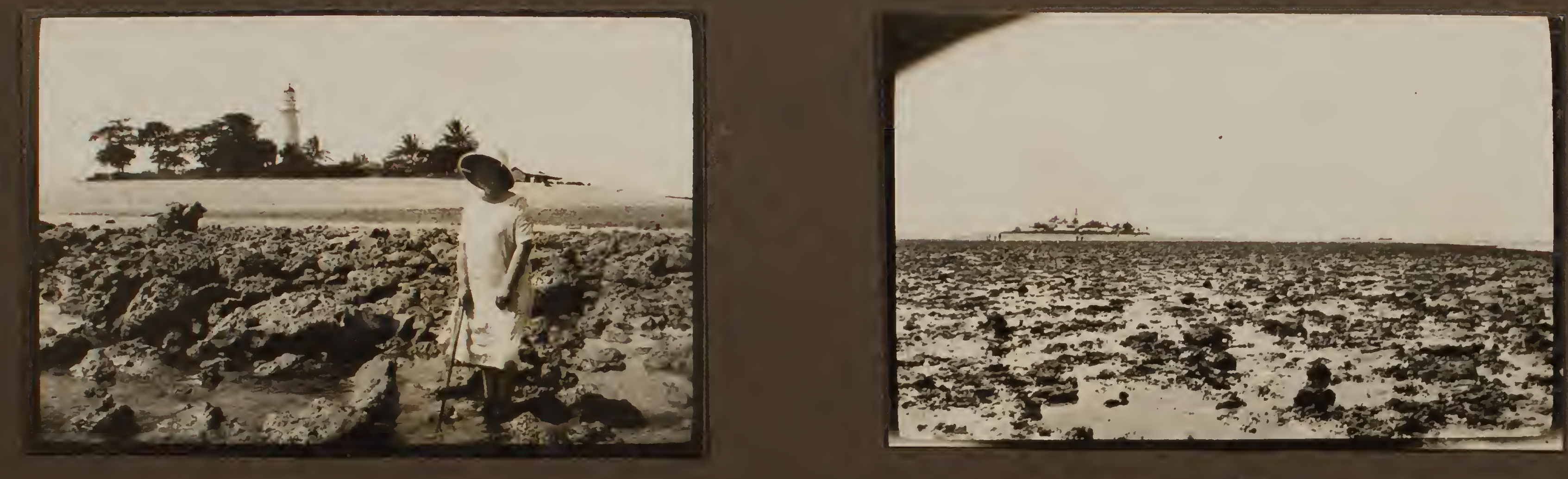

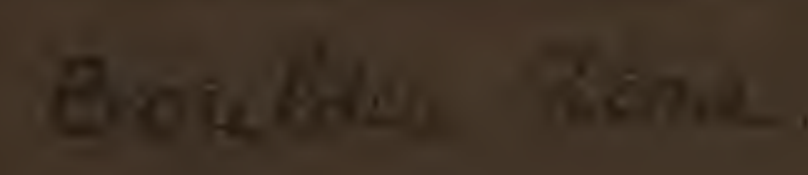
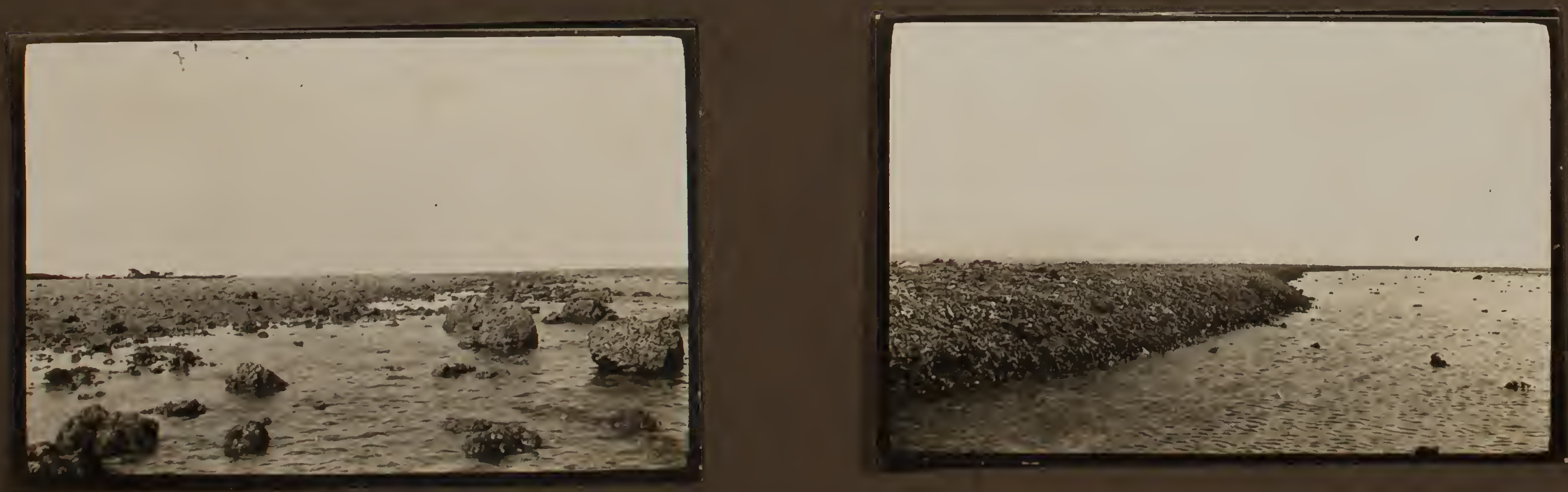

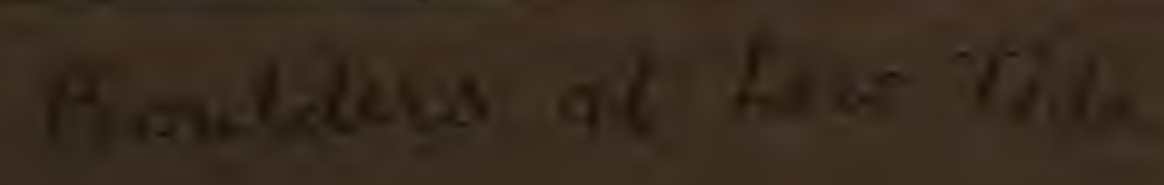



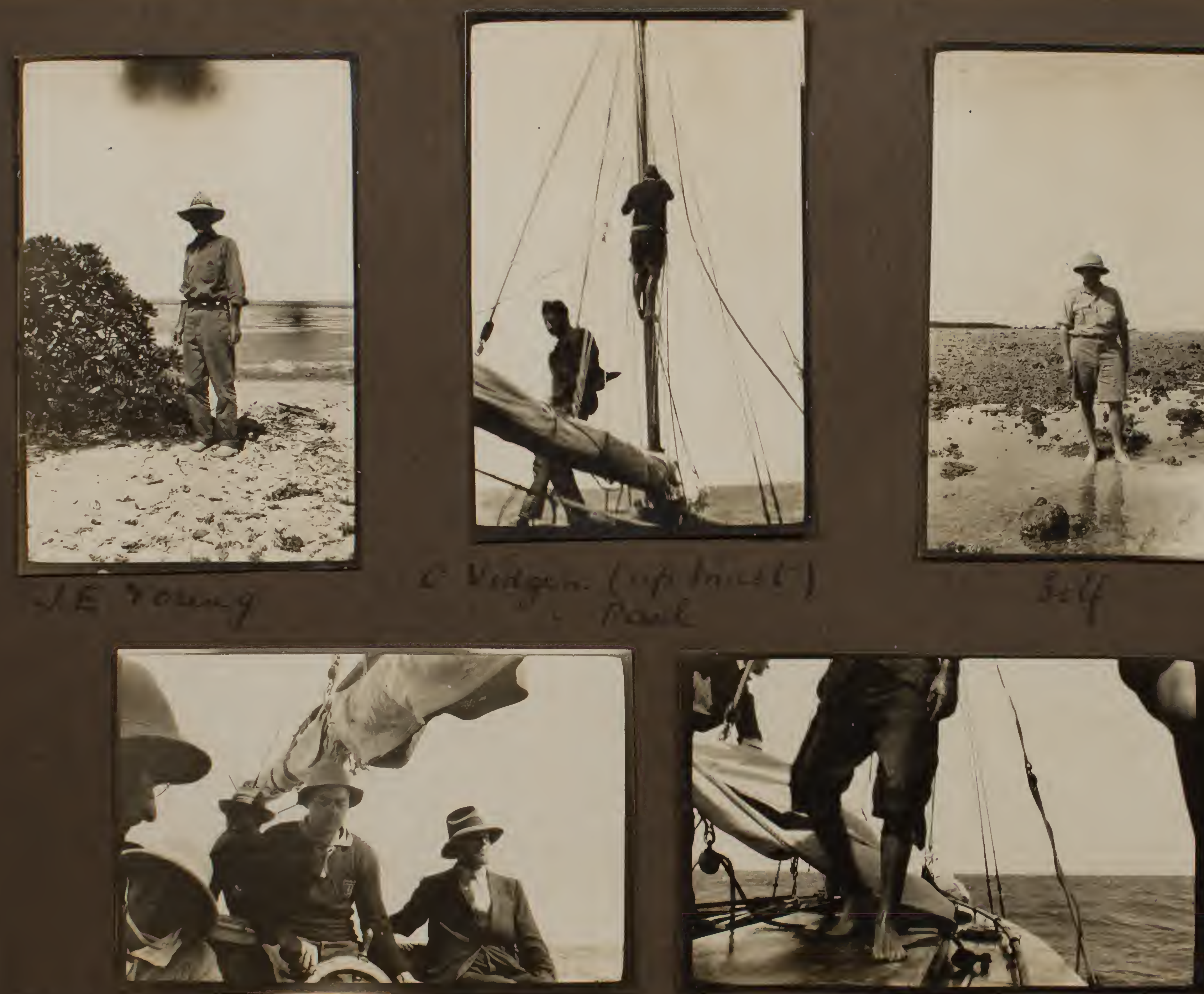

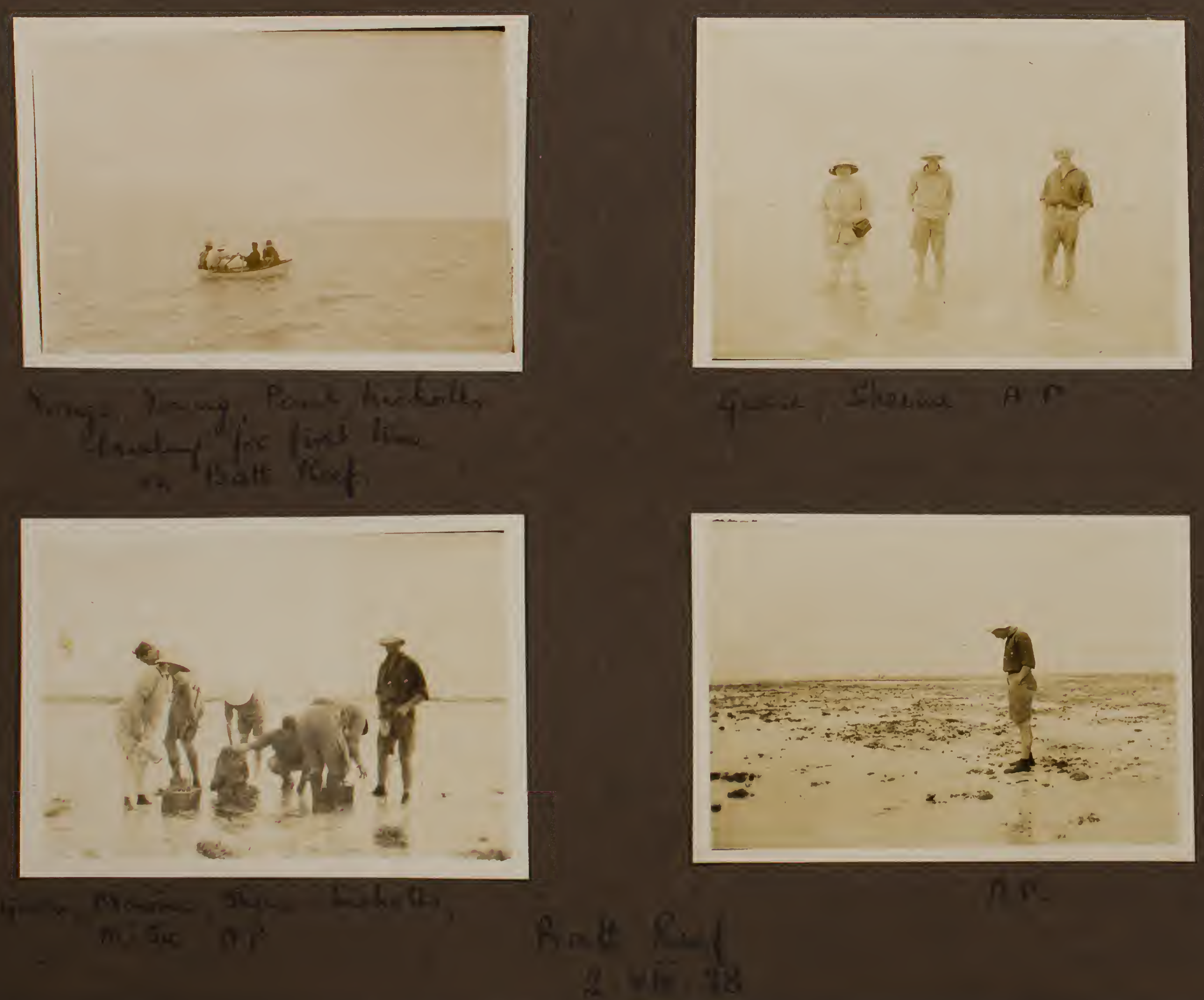

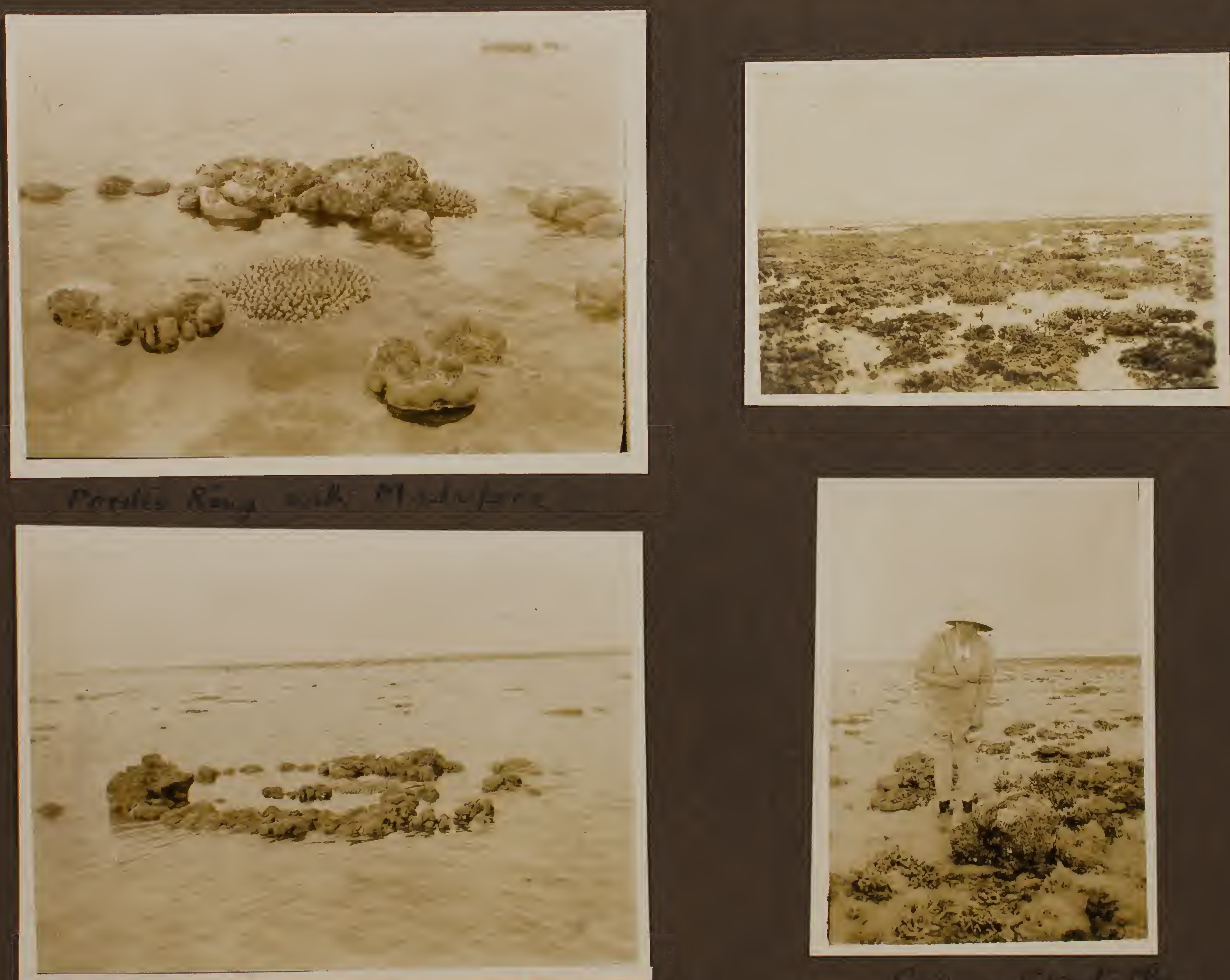

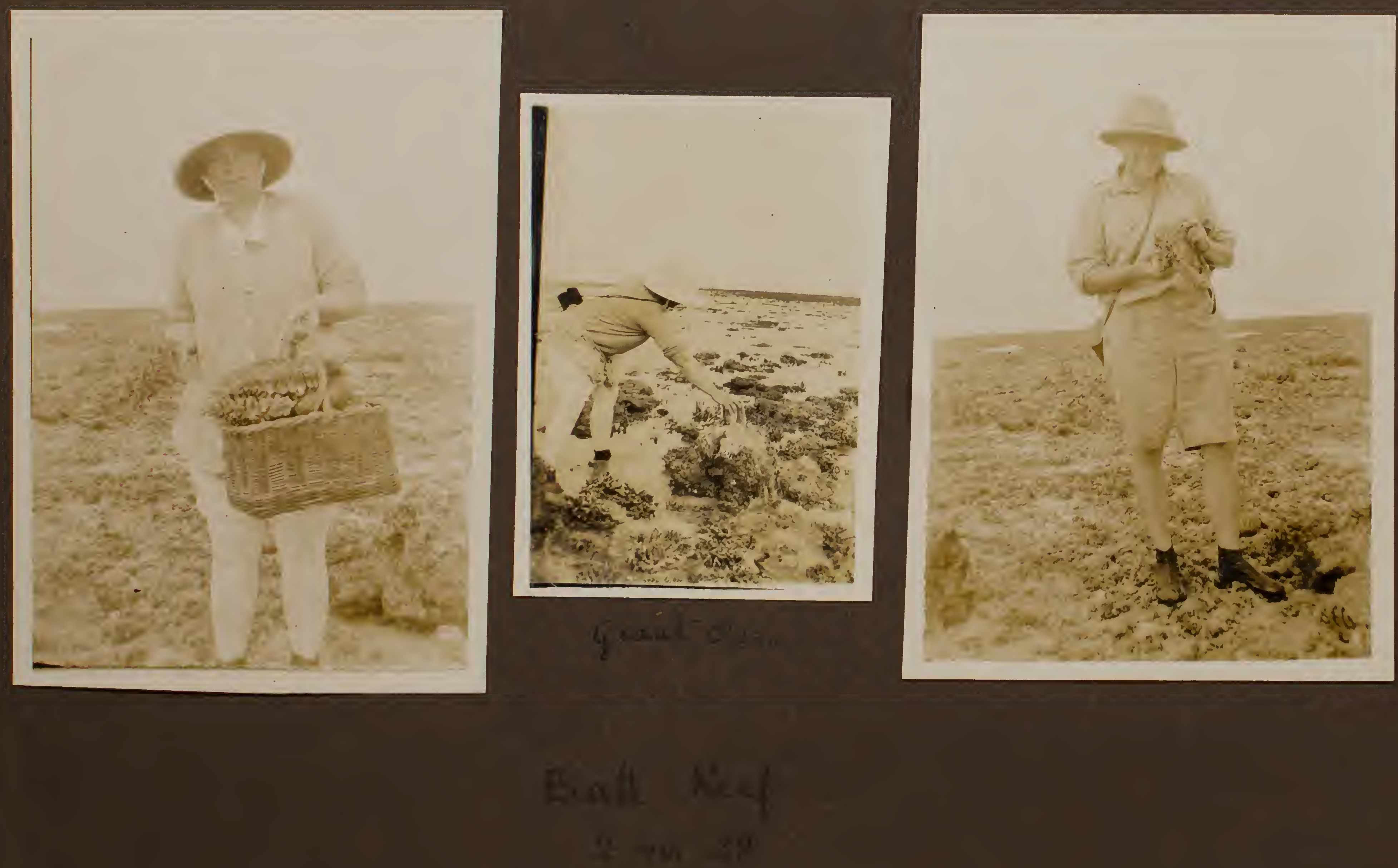

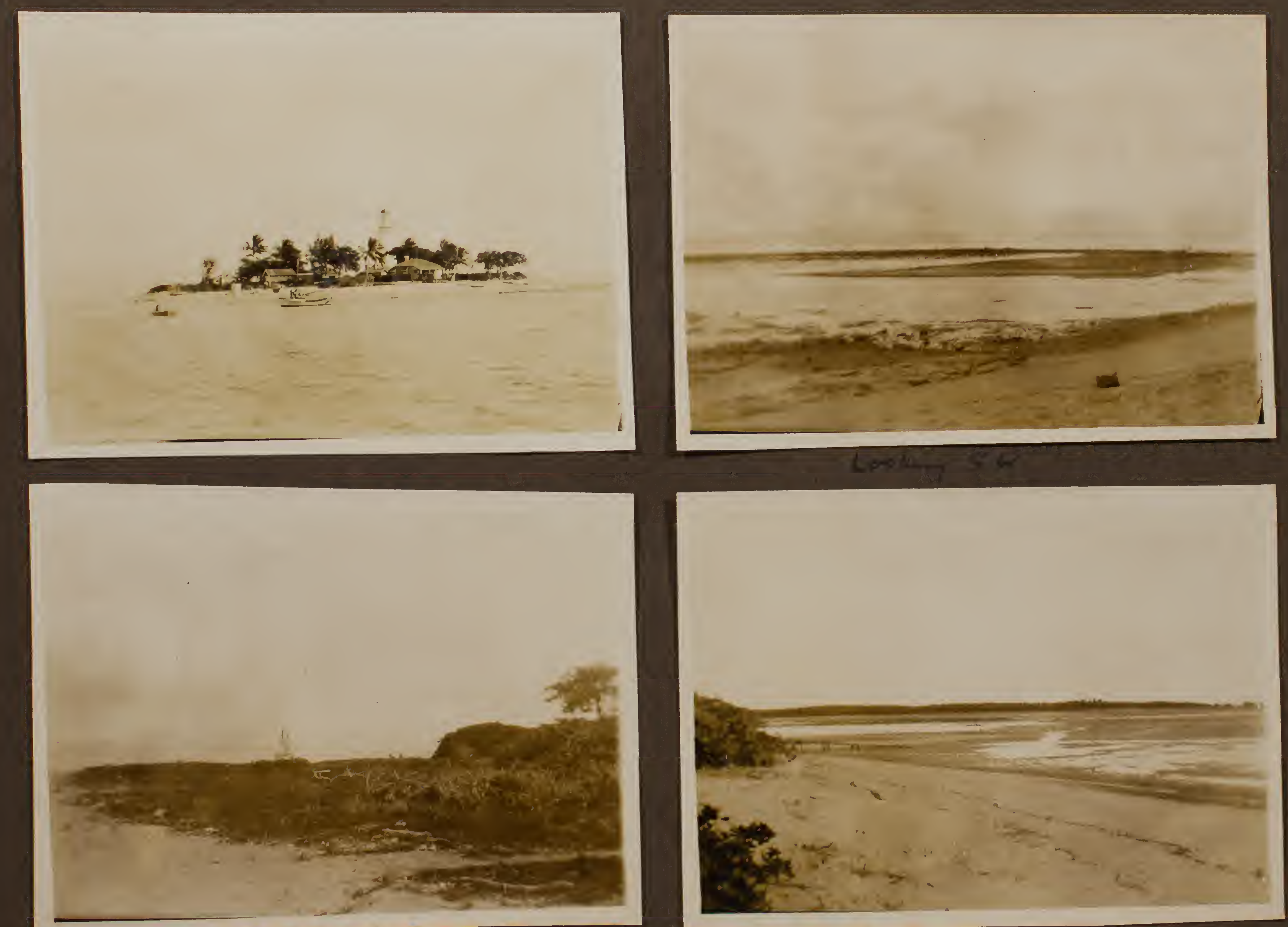


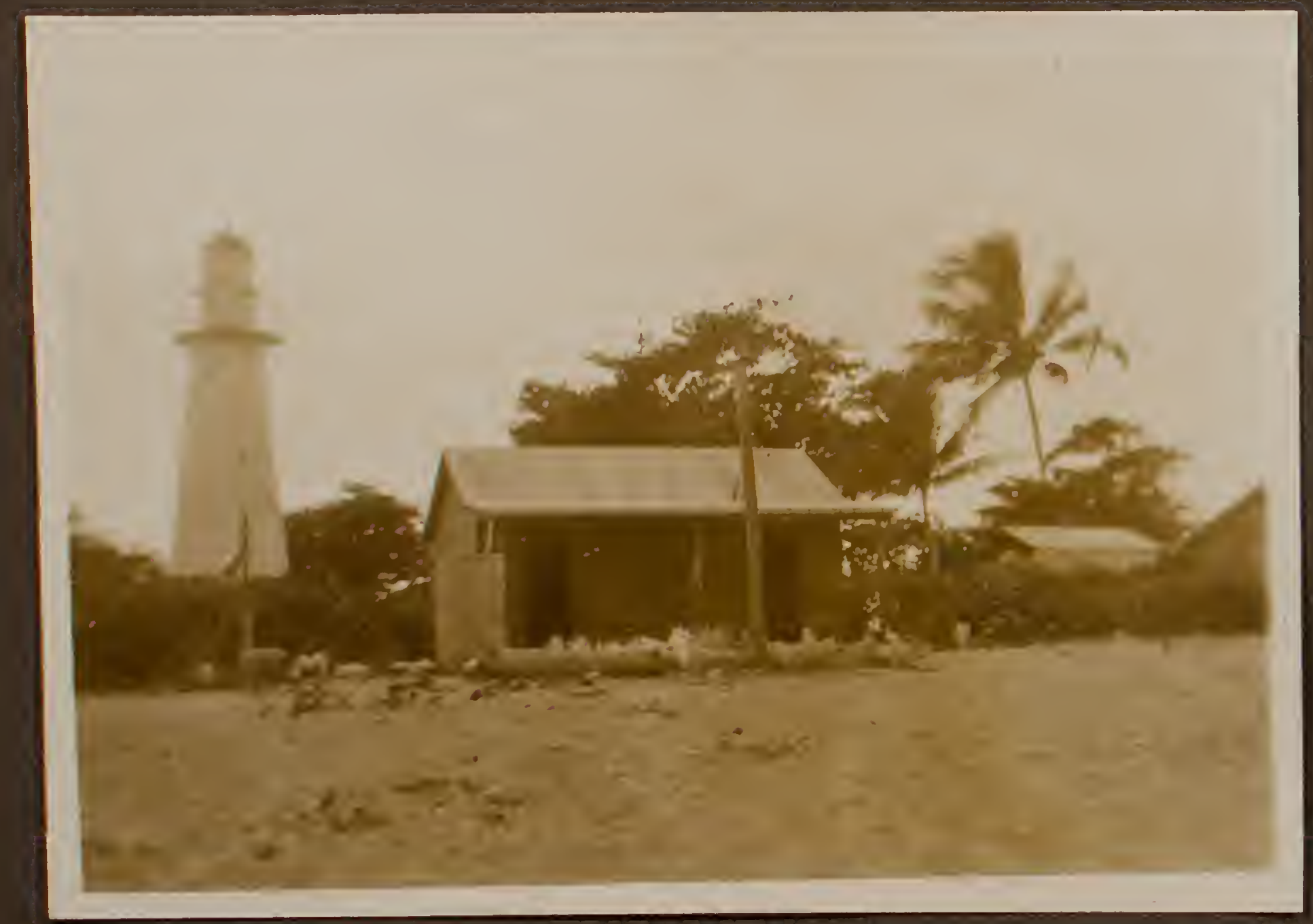

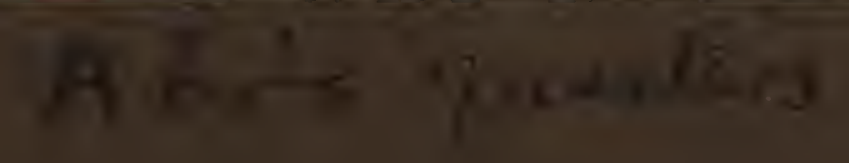

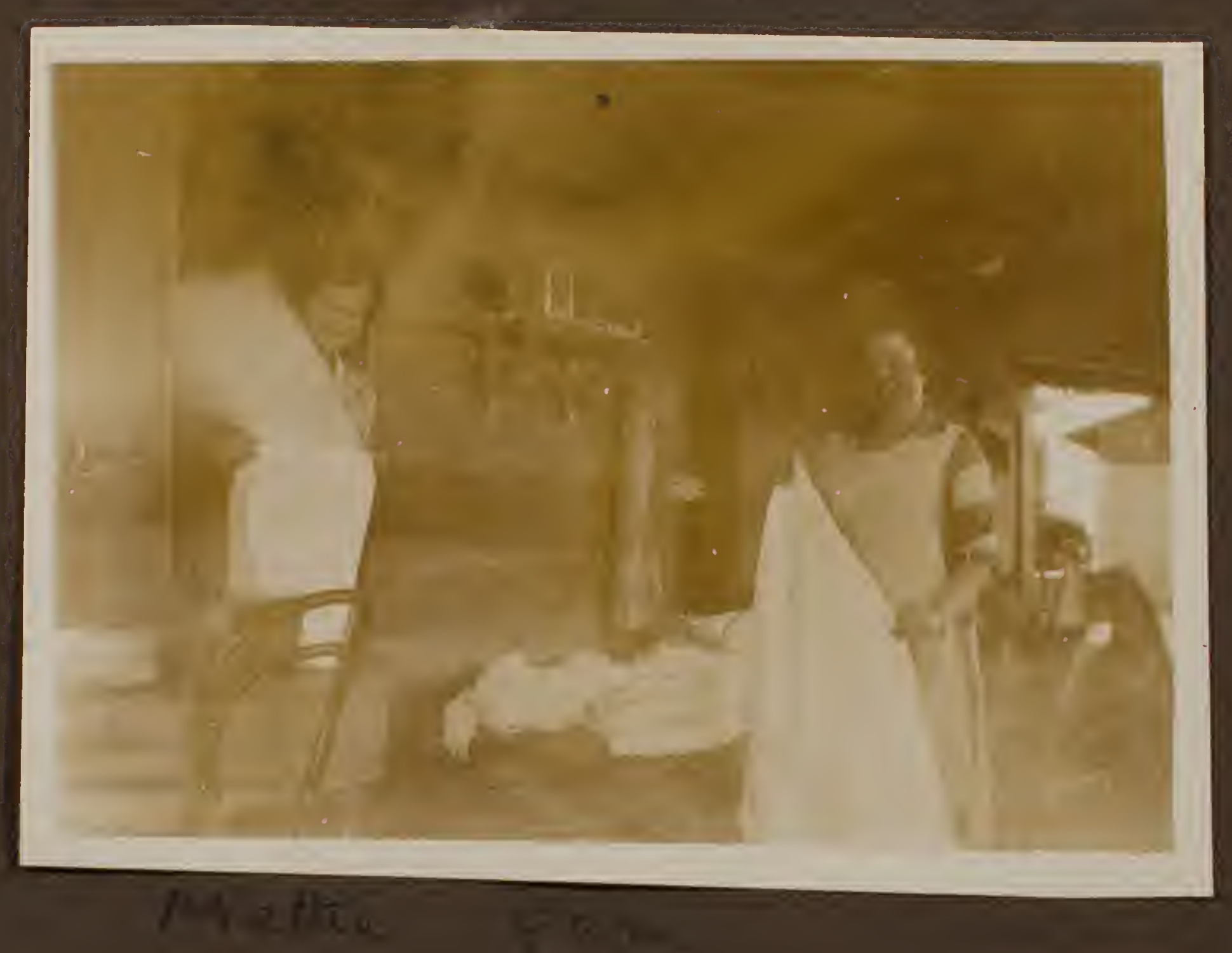

a

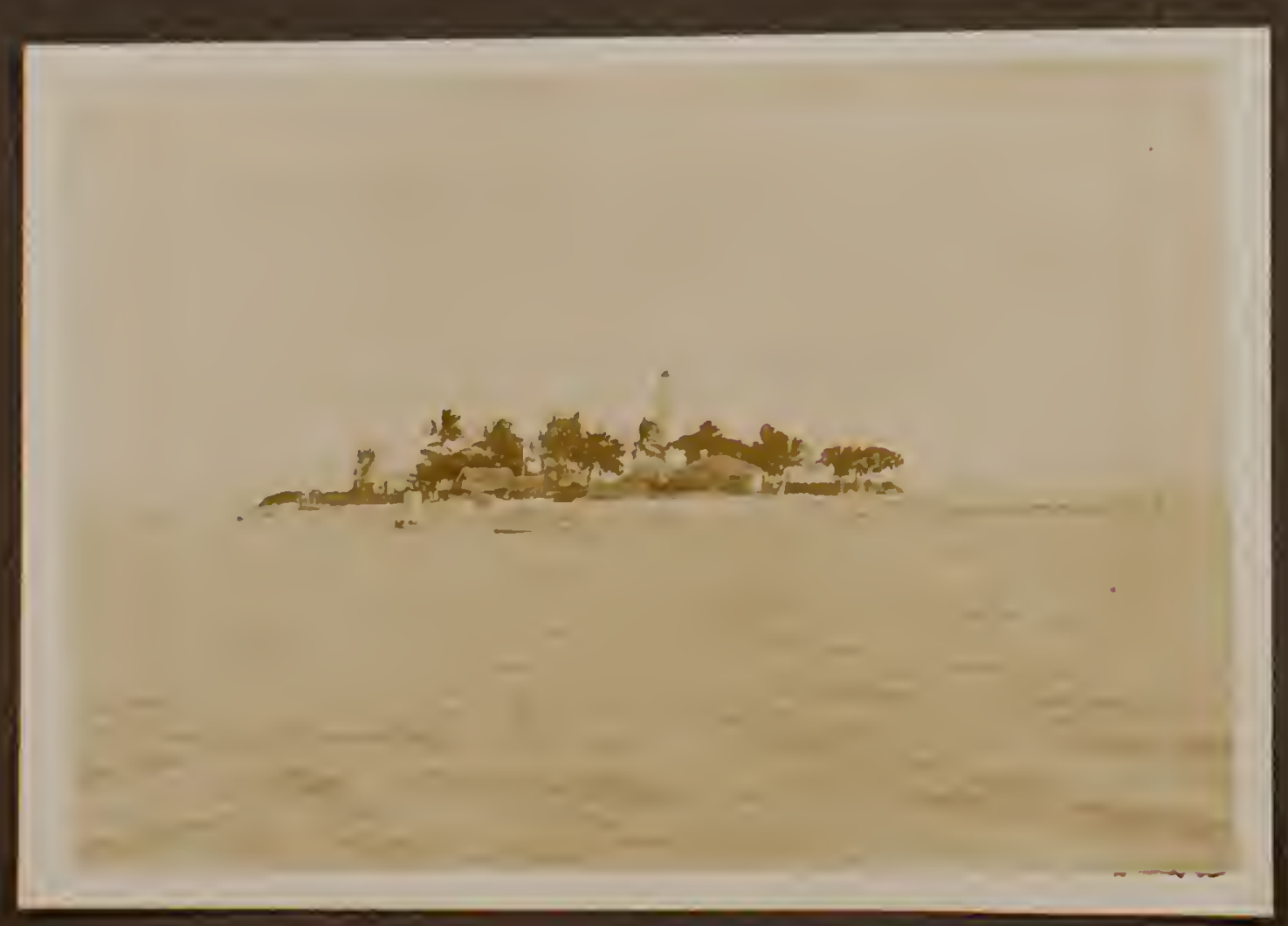



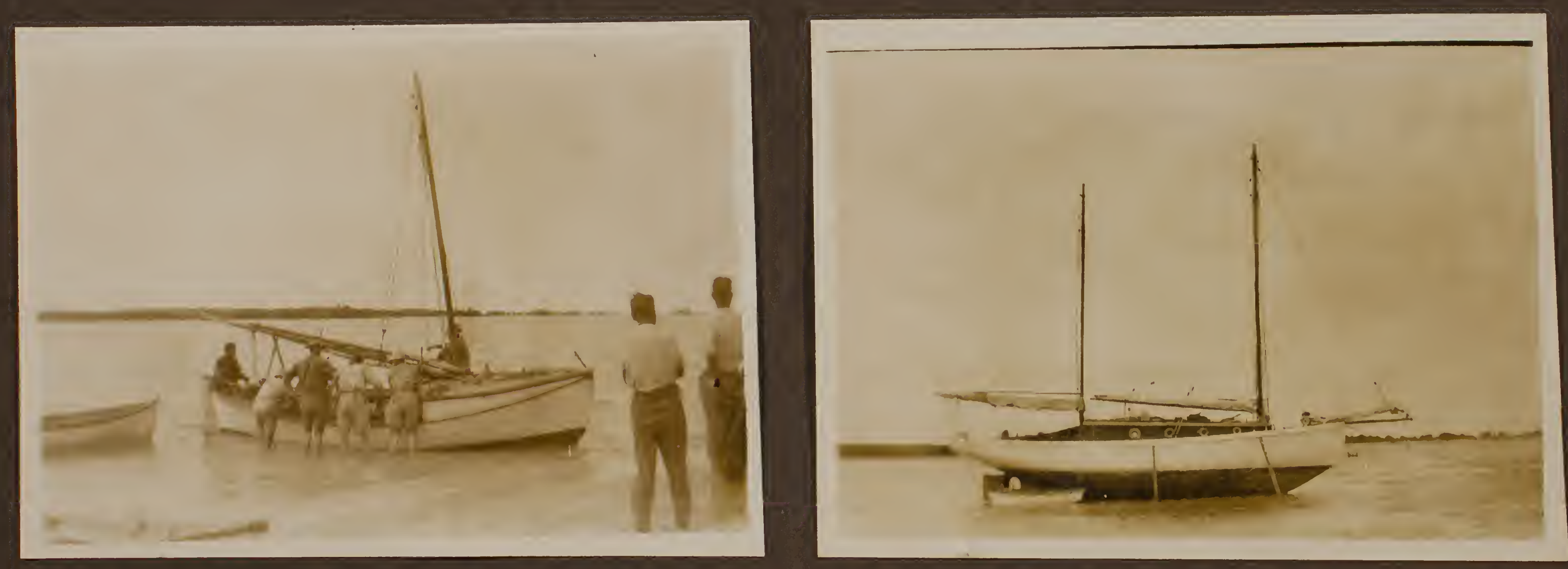

3 

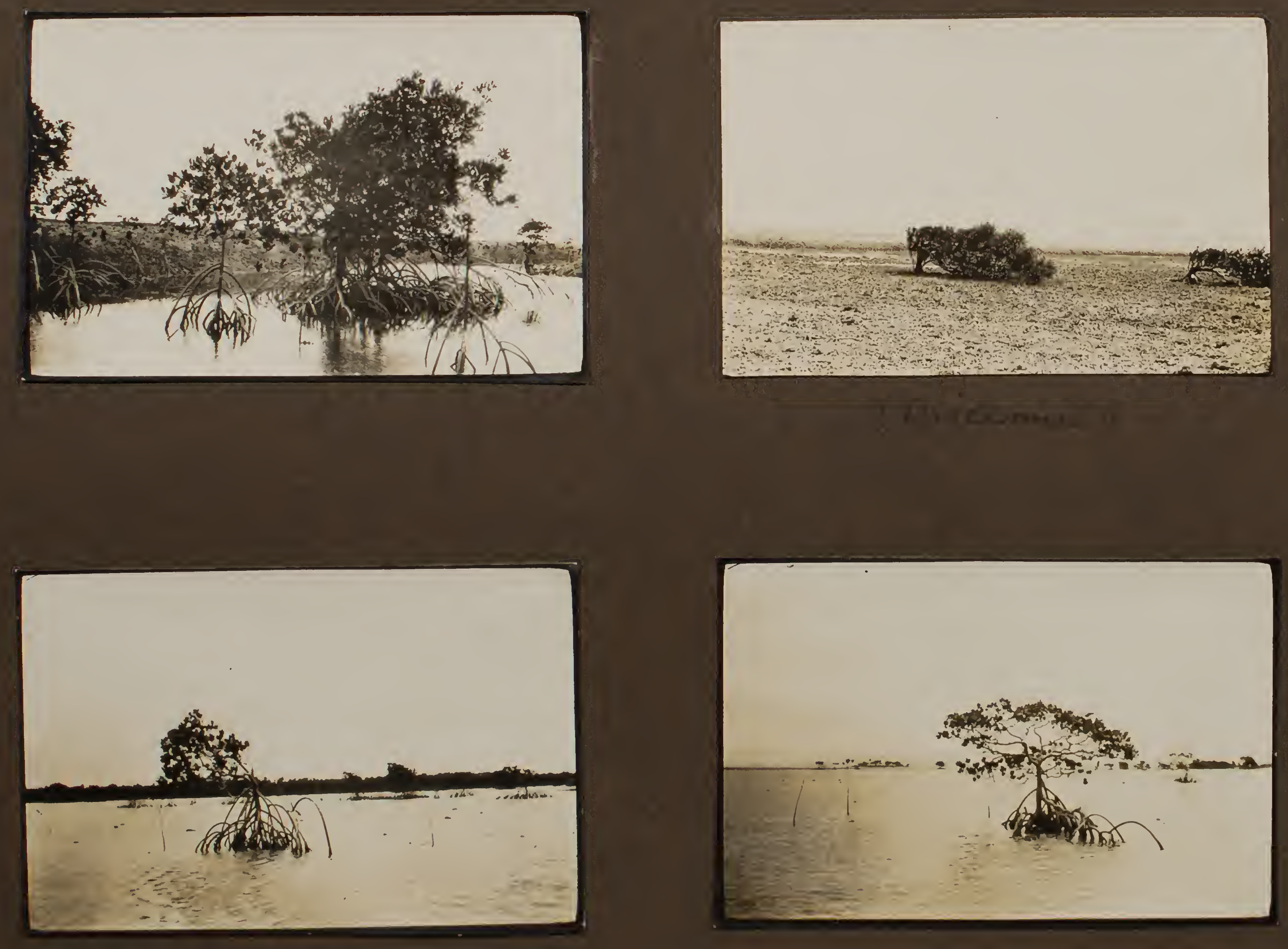


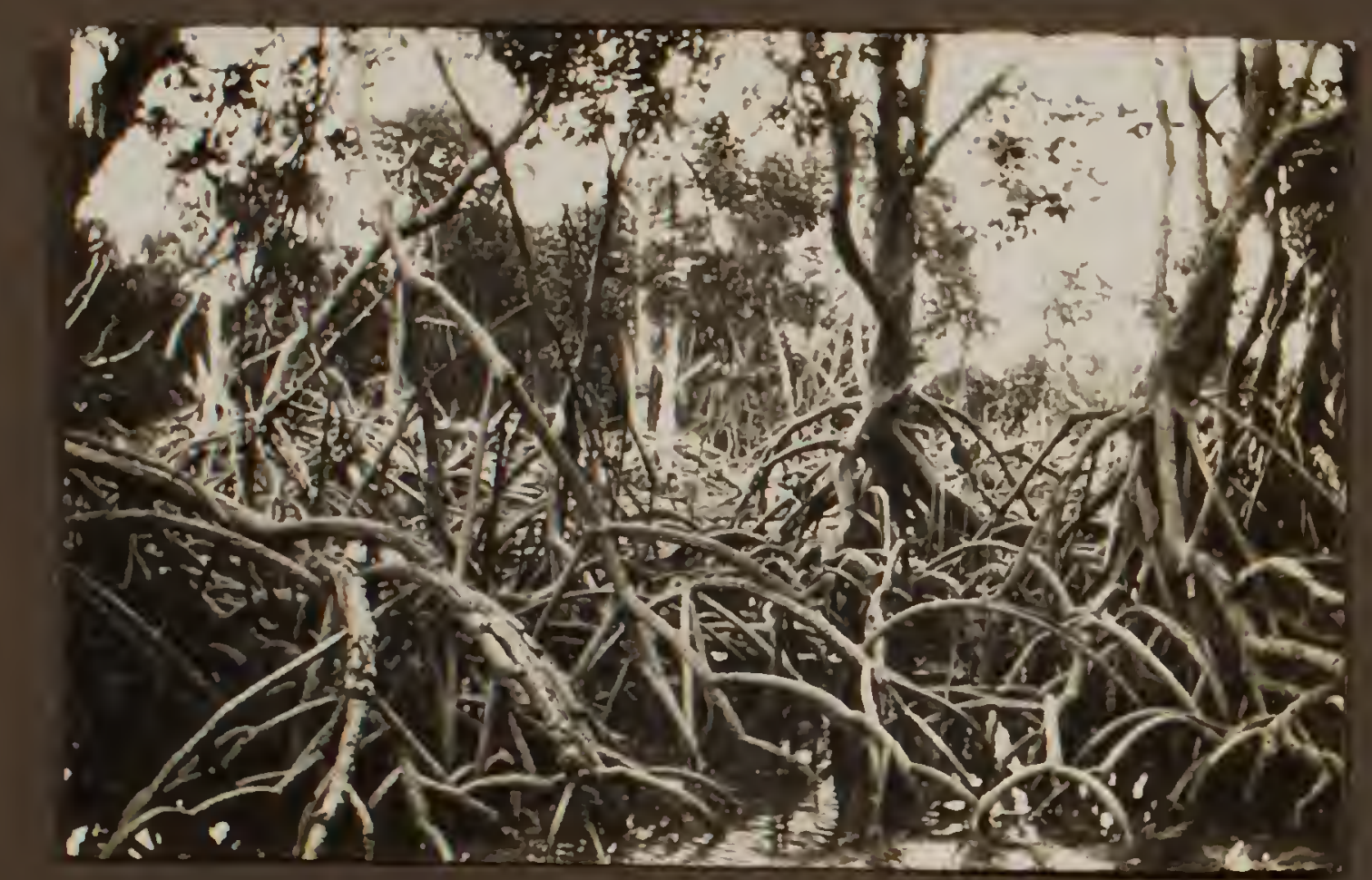

Rook

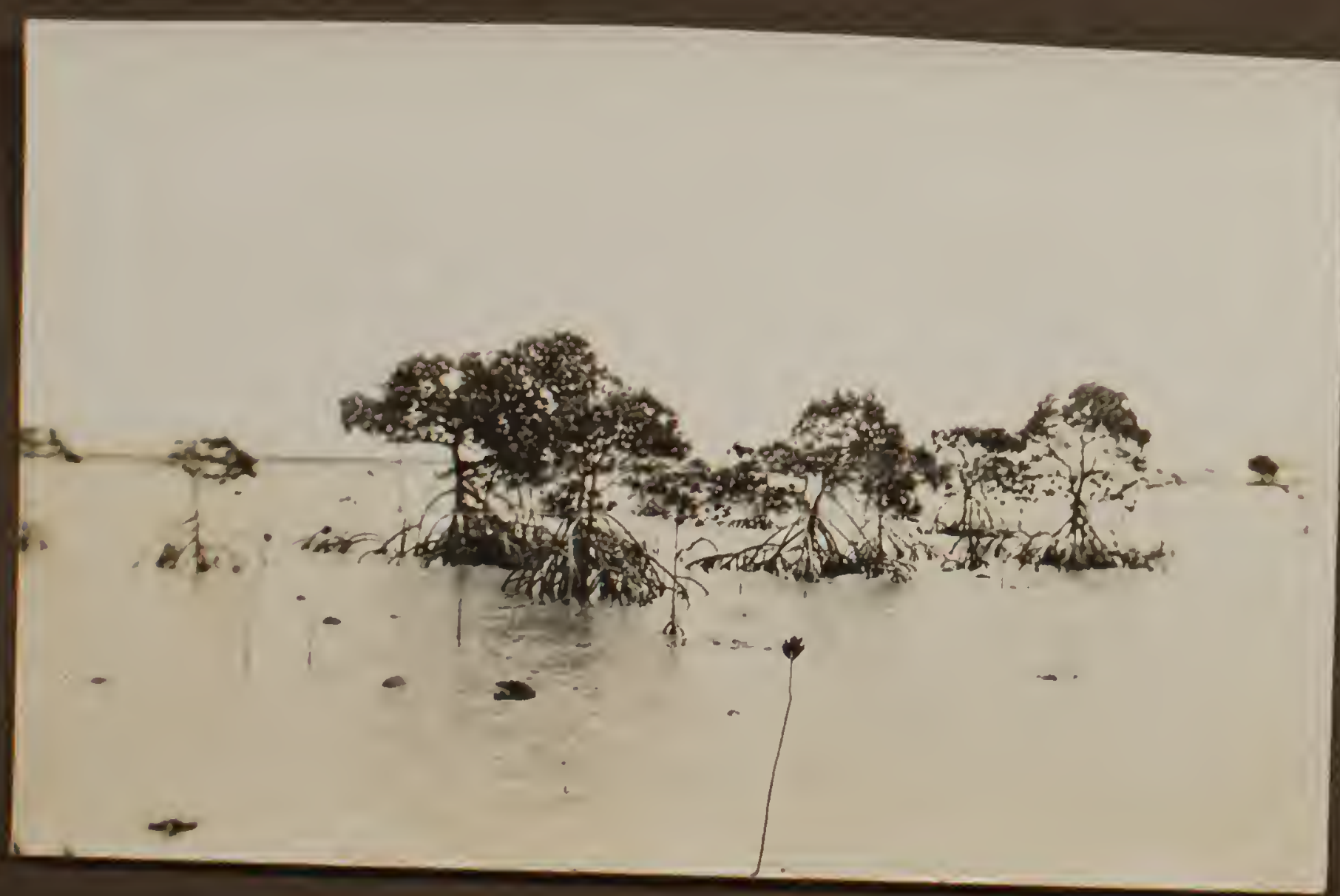

21. Mn

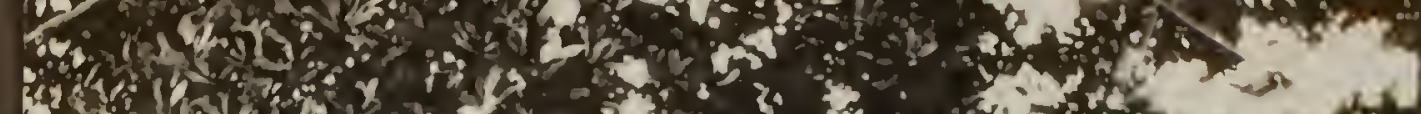
S

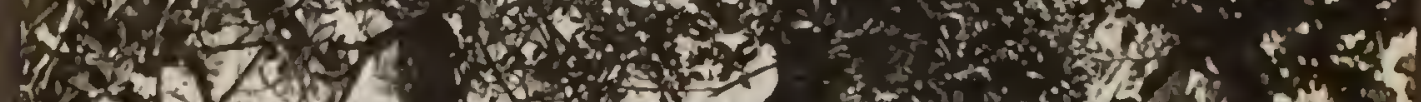

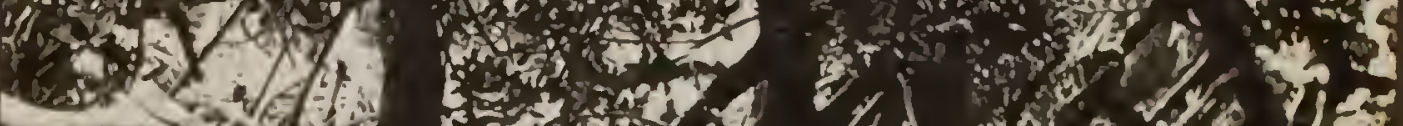
T.1.5.

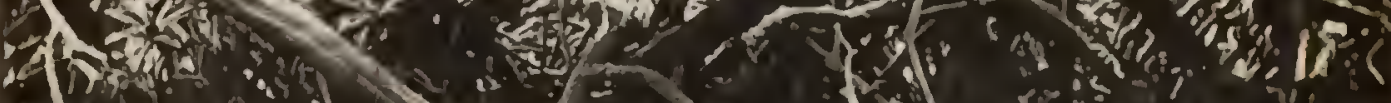

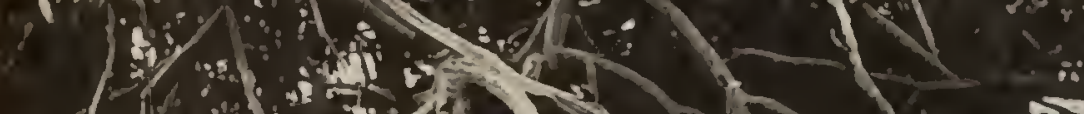

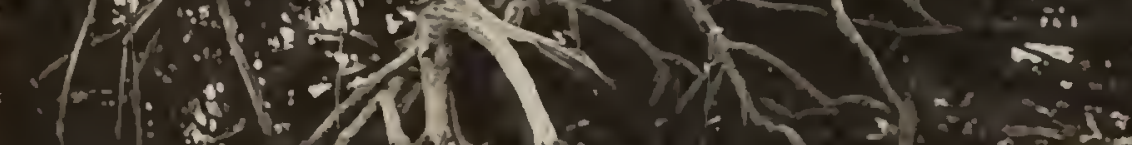

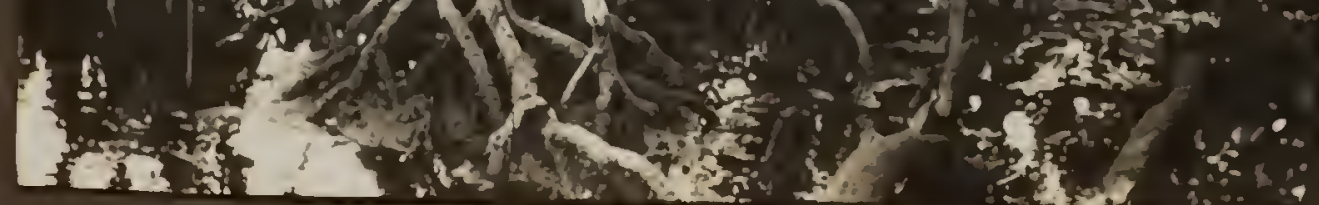

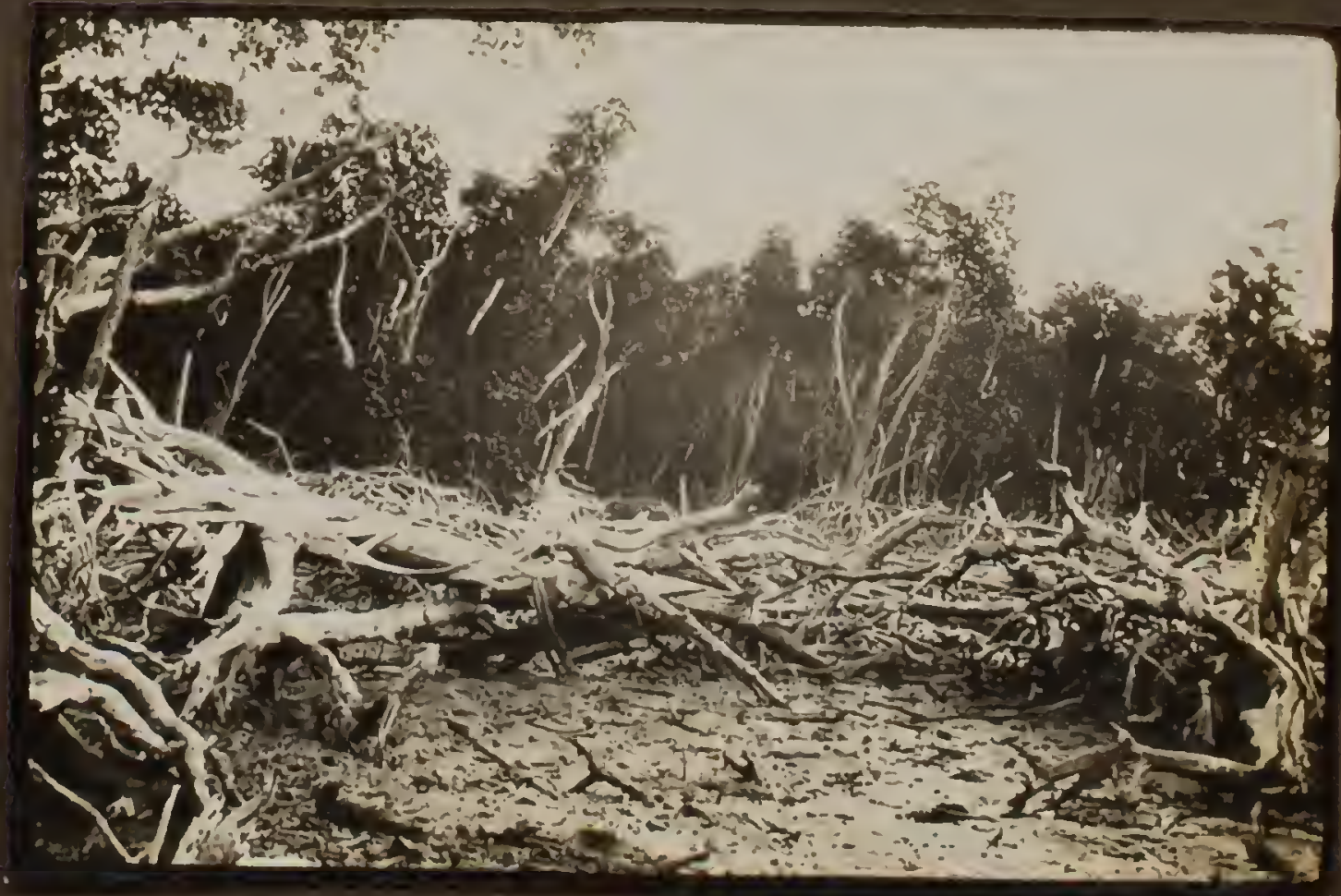

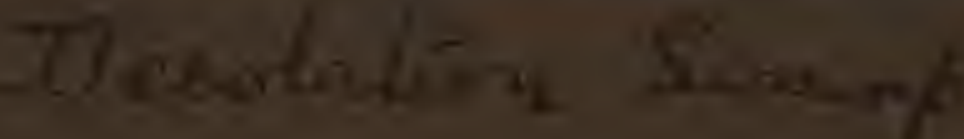




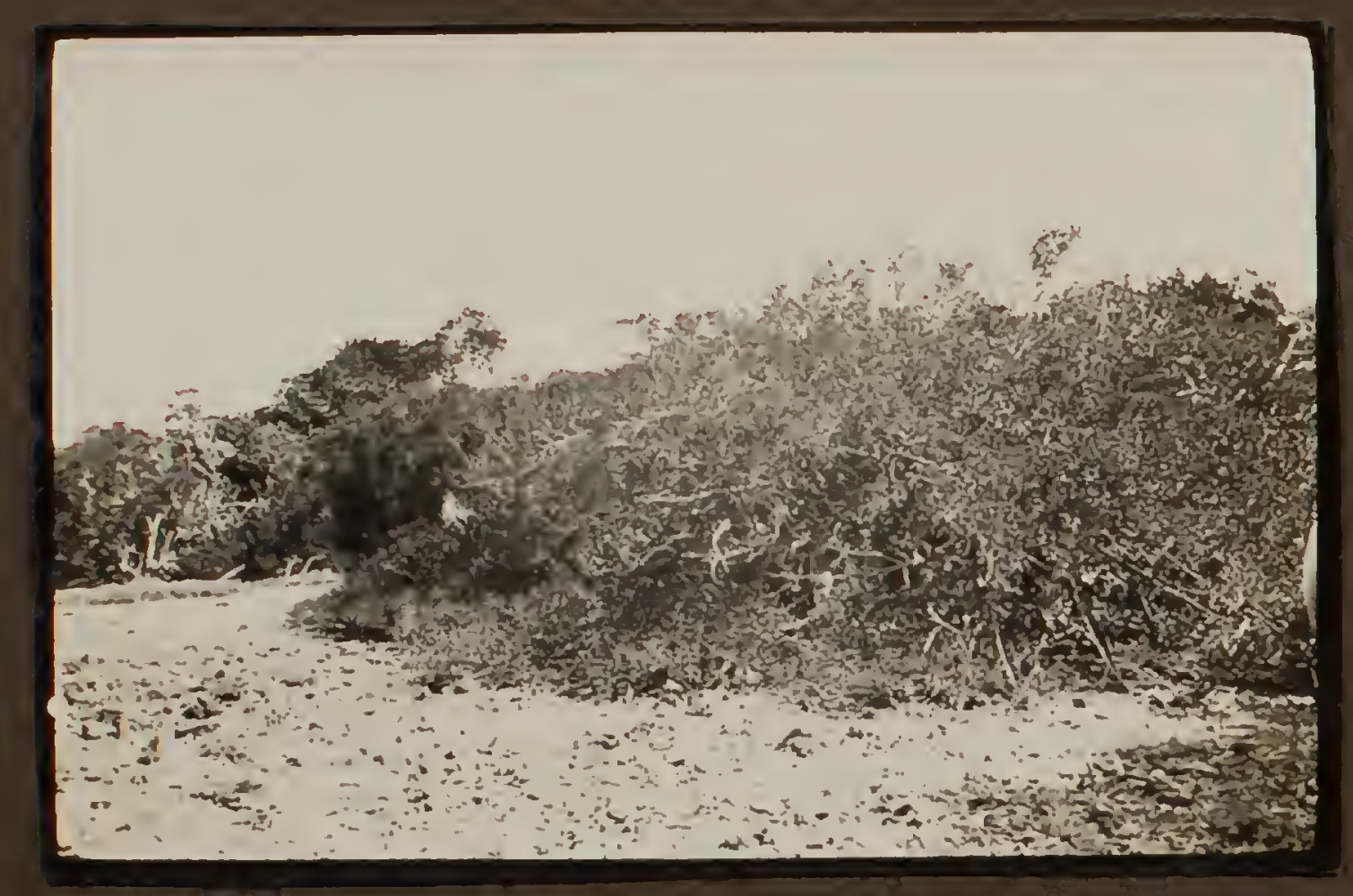

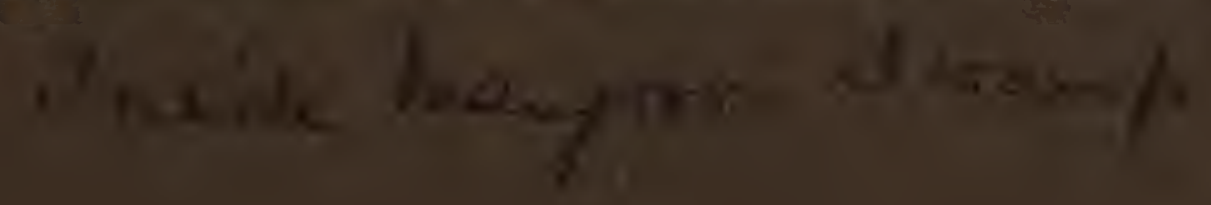

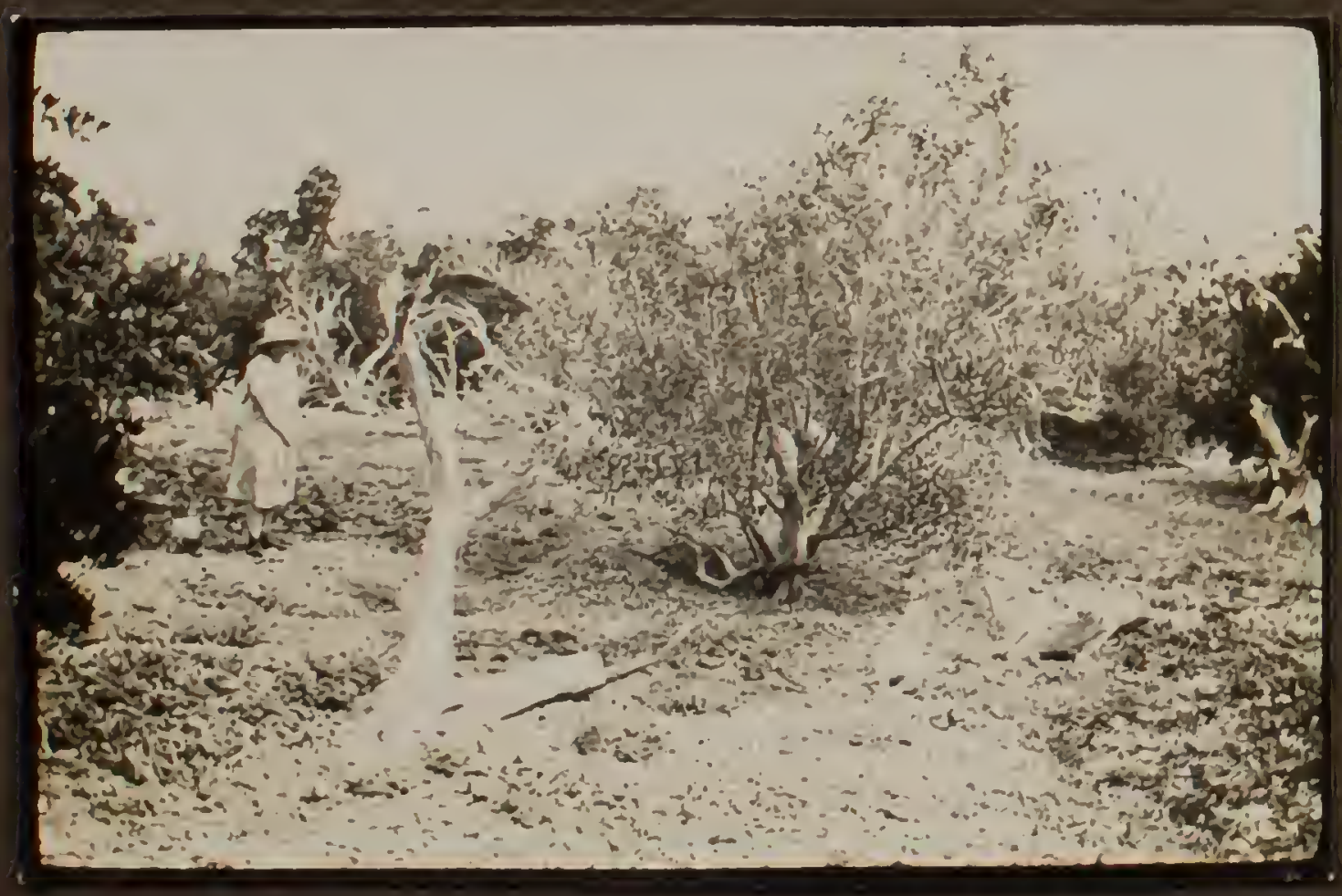

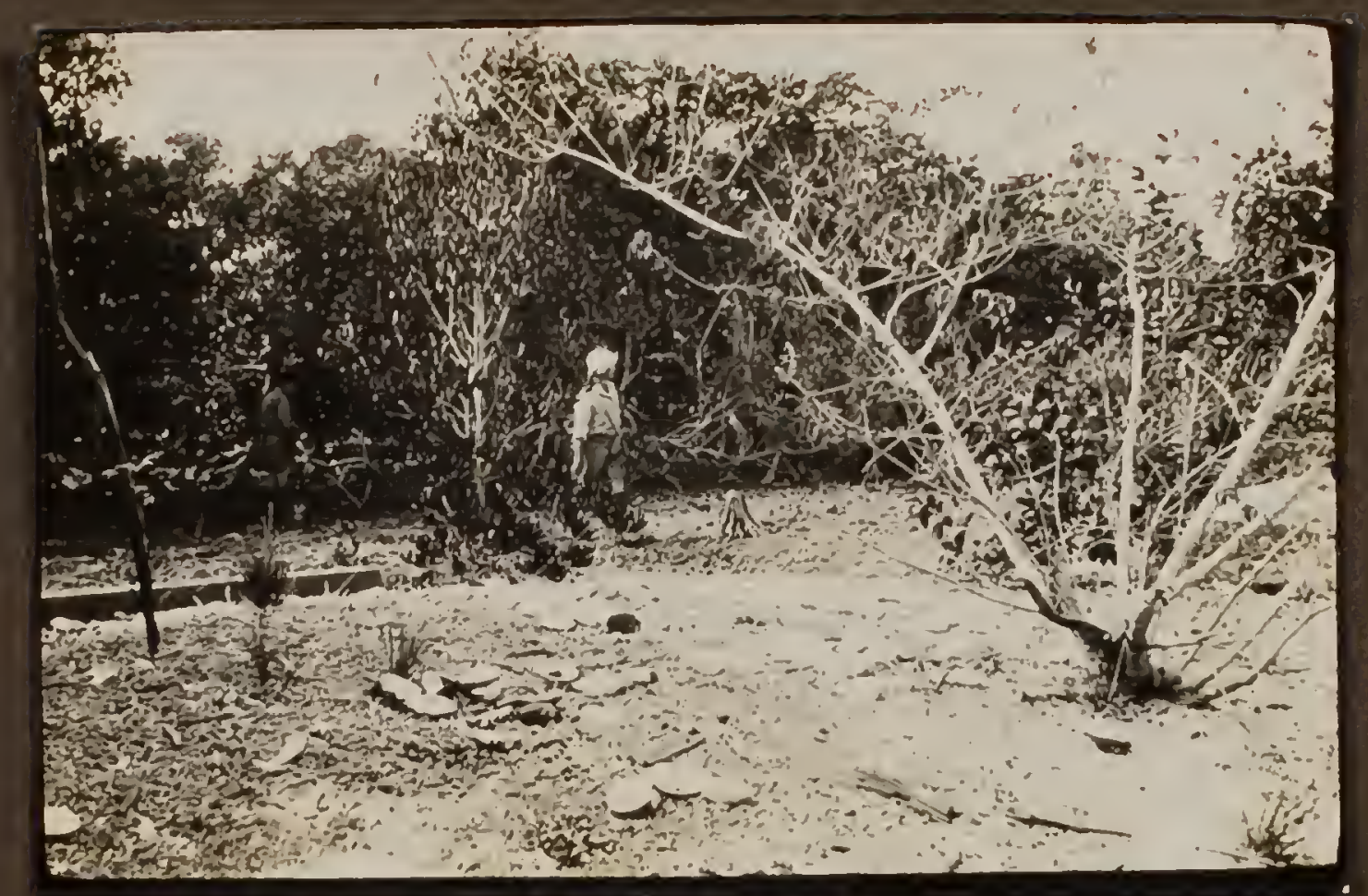
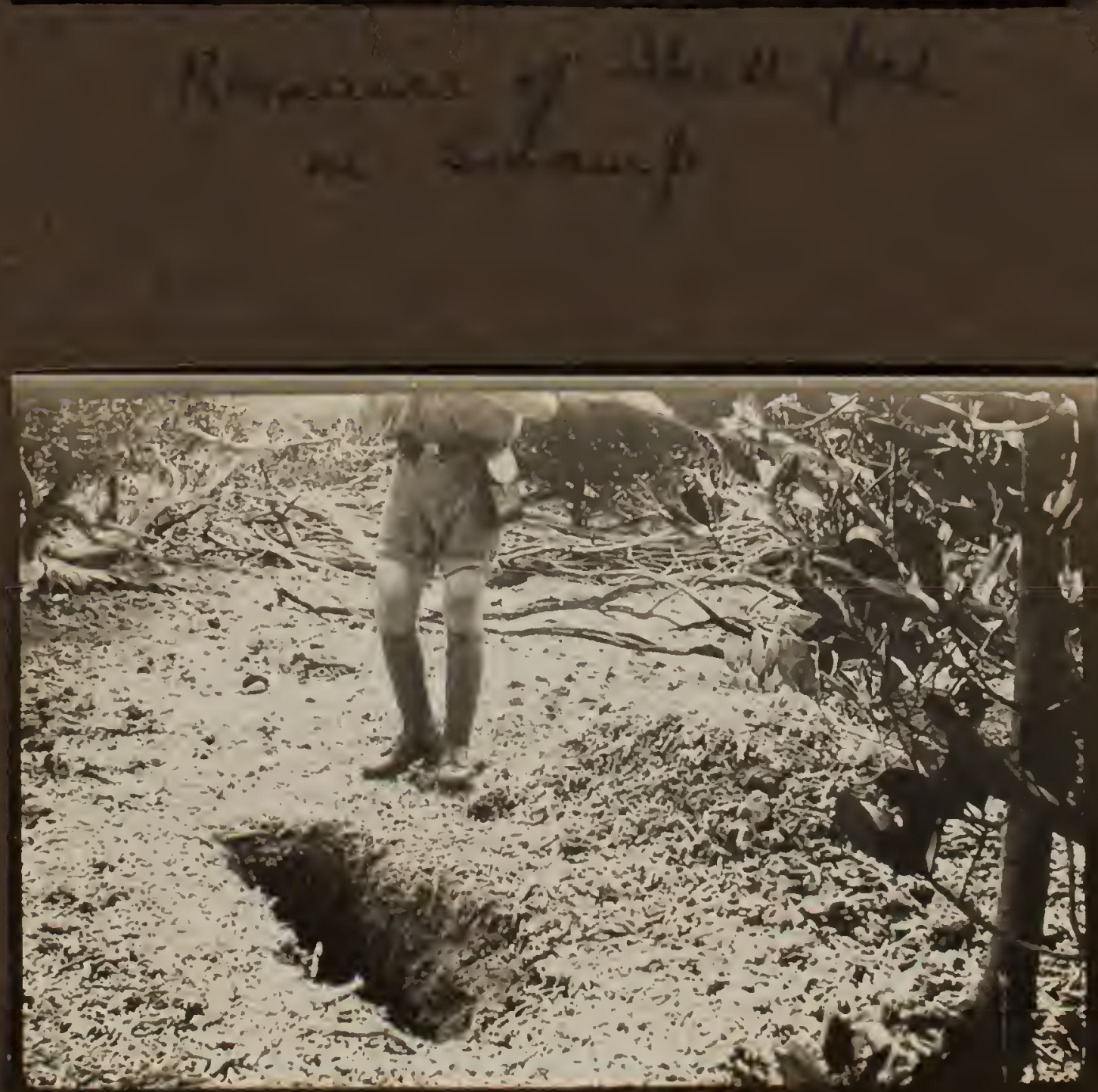

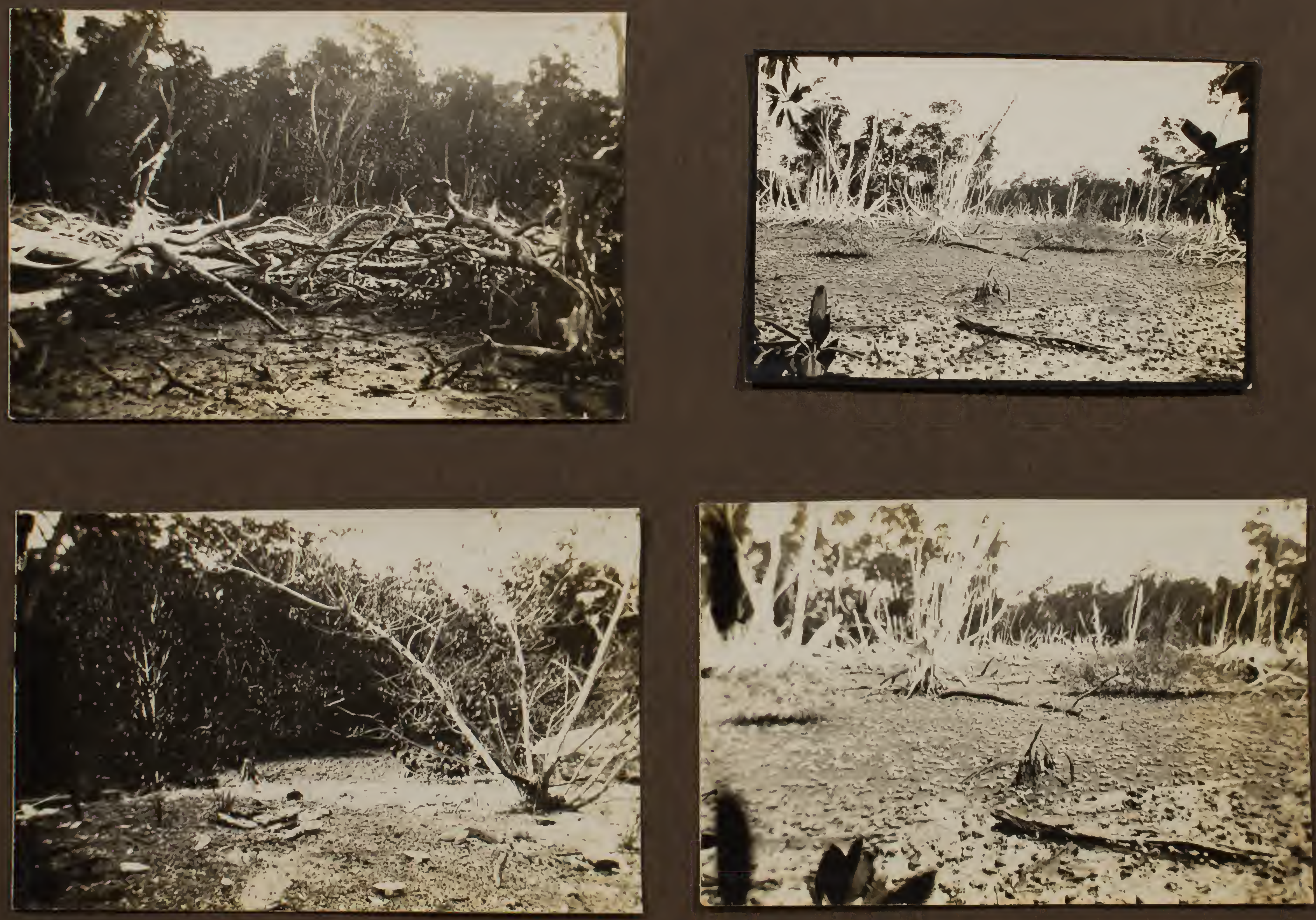

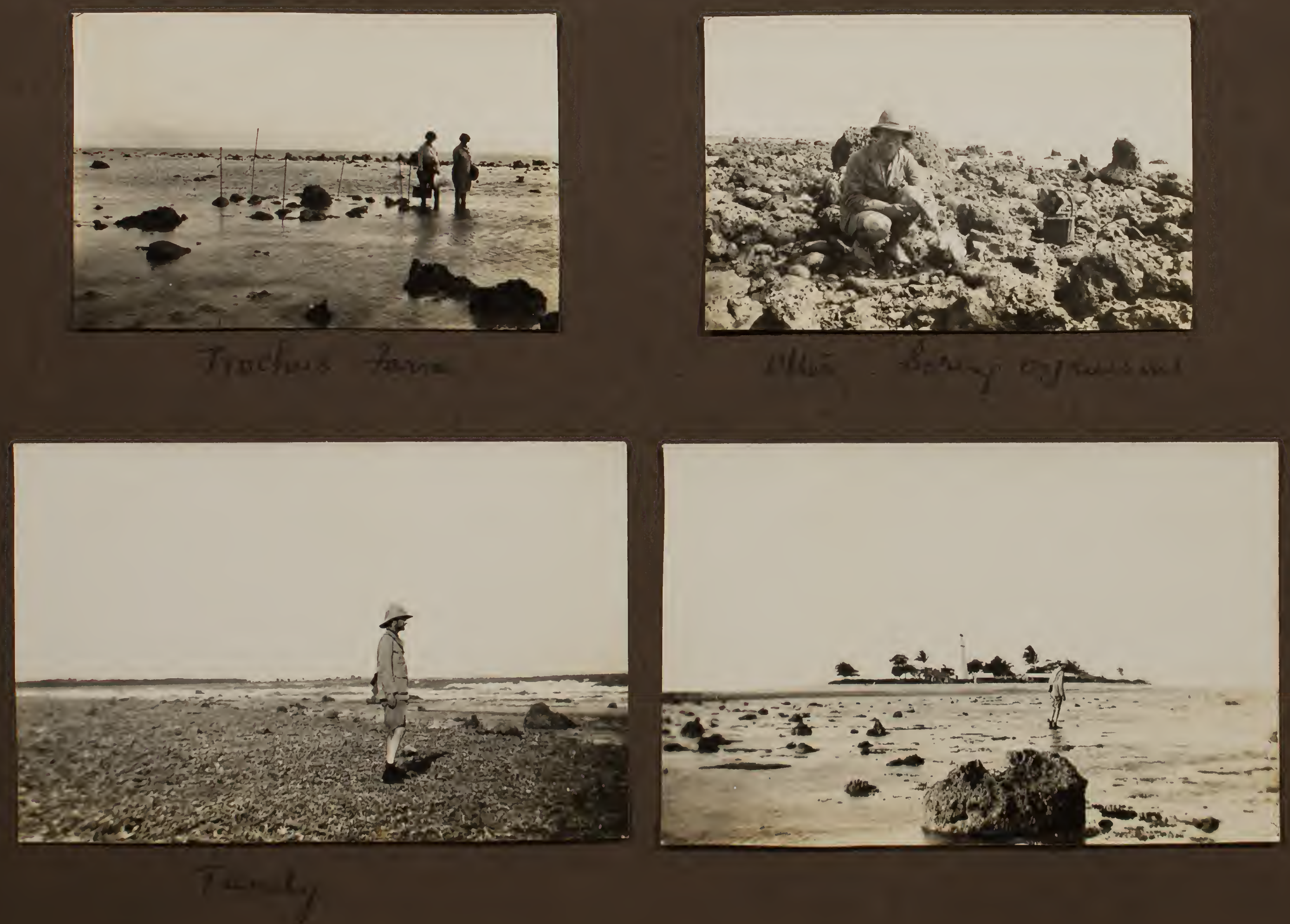

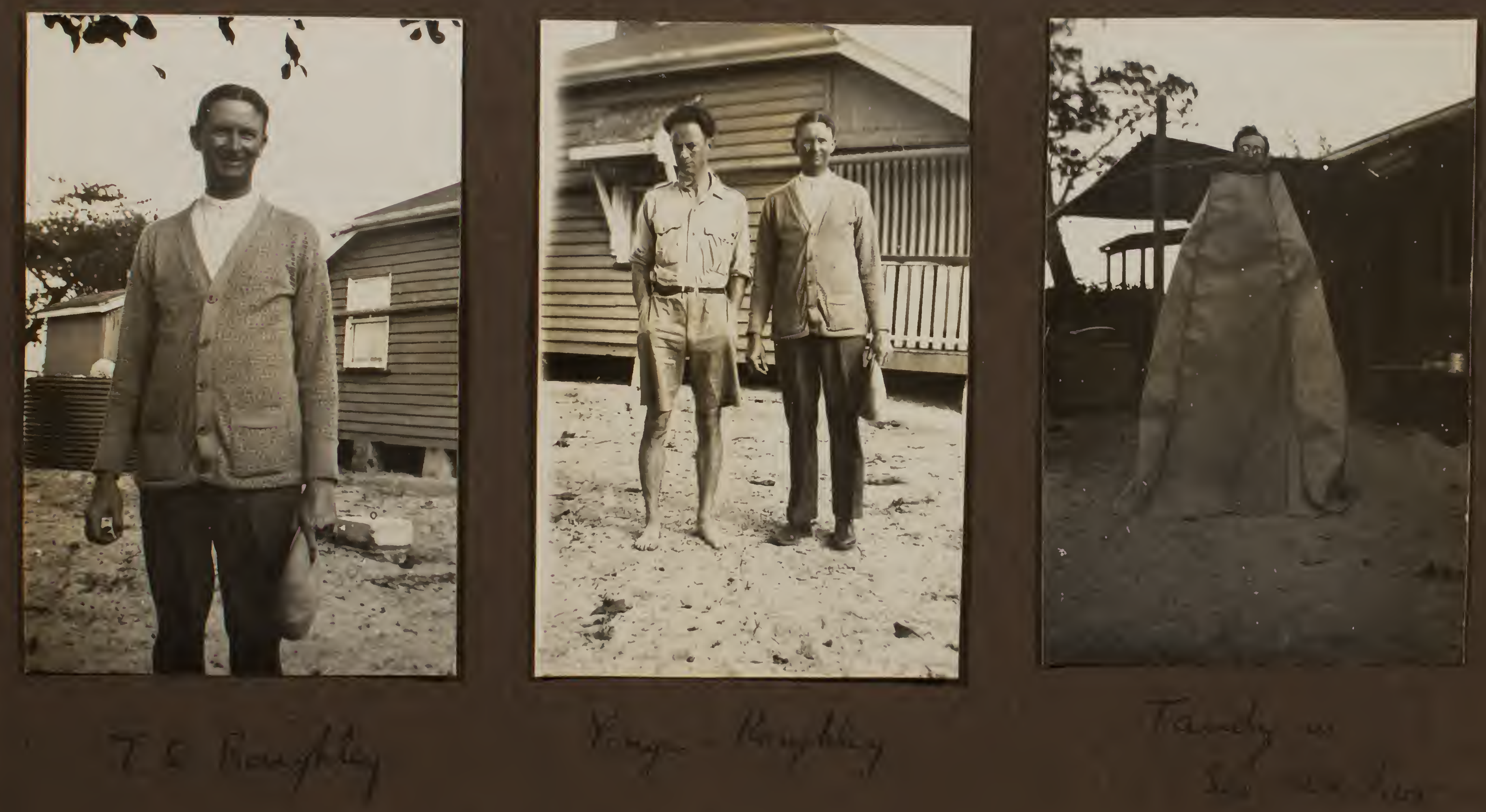


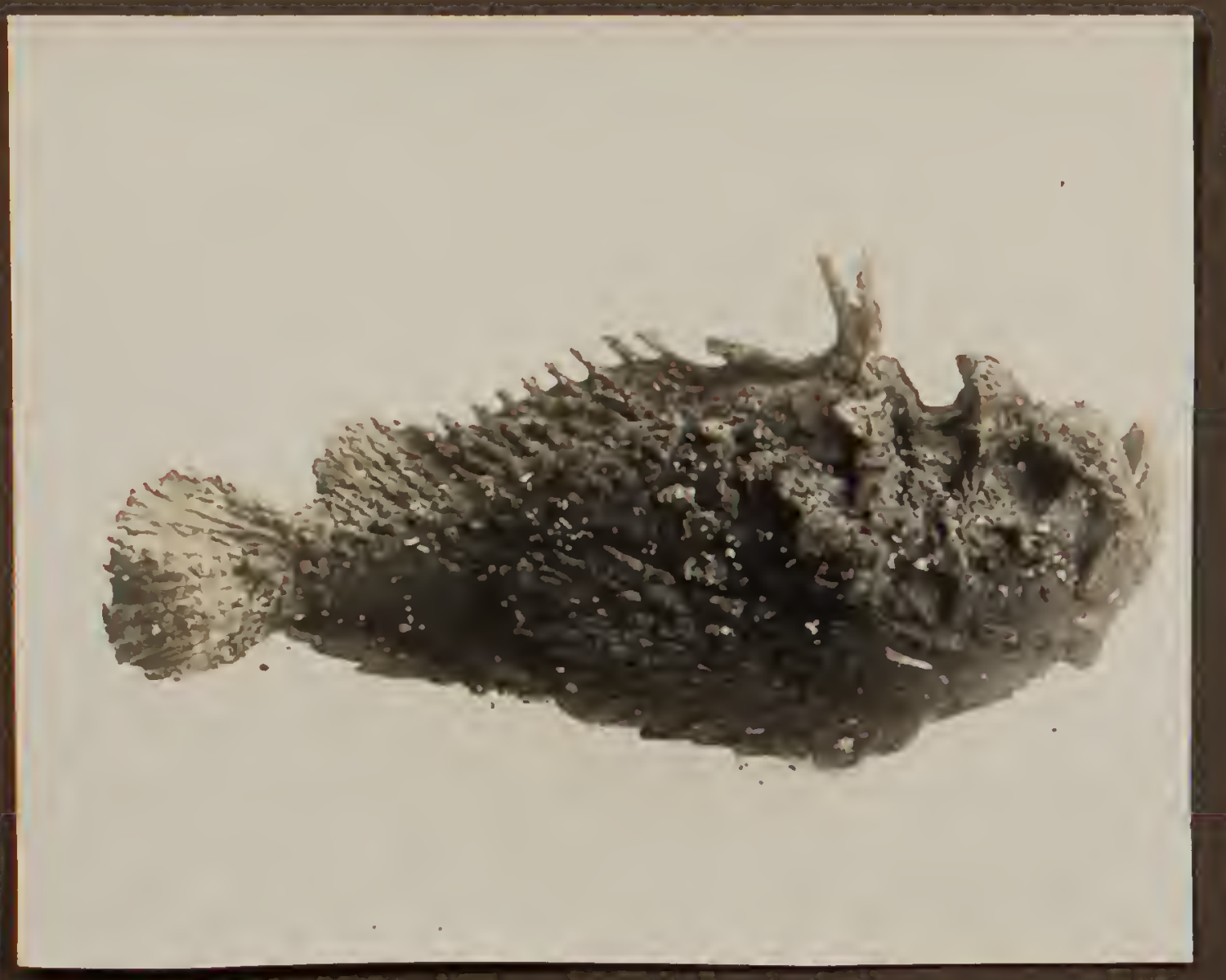

Ston zich

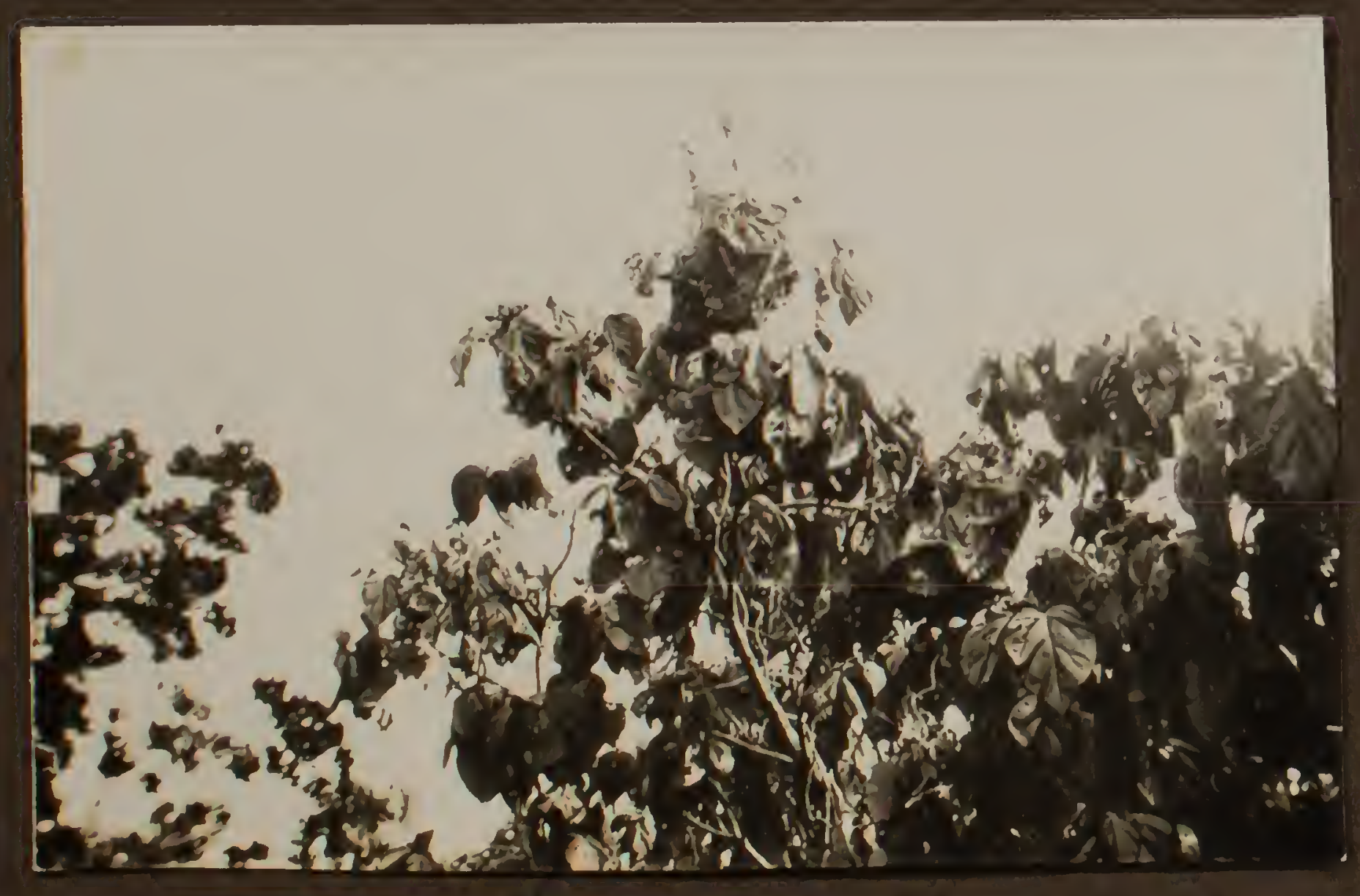

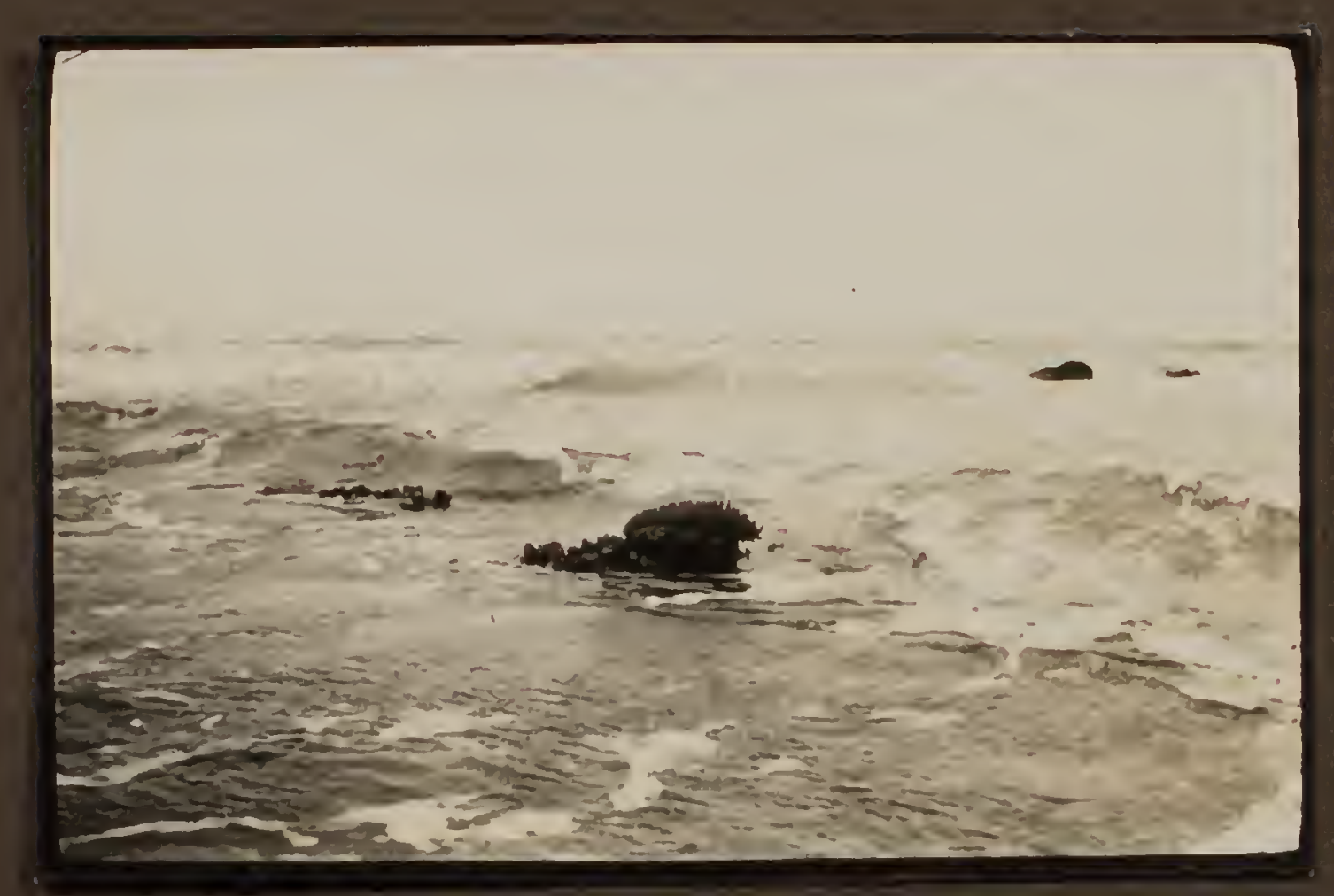

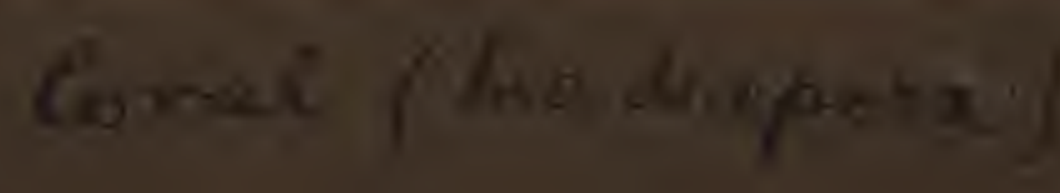
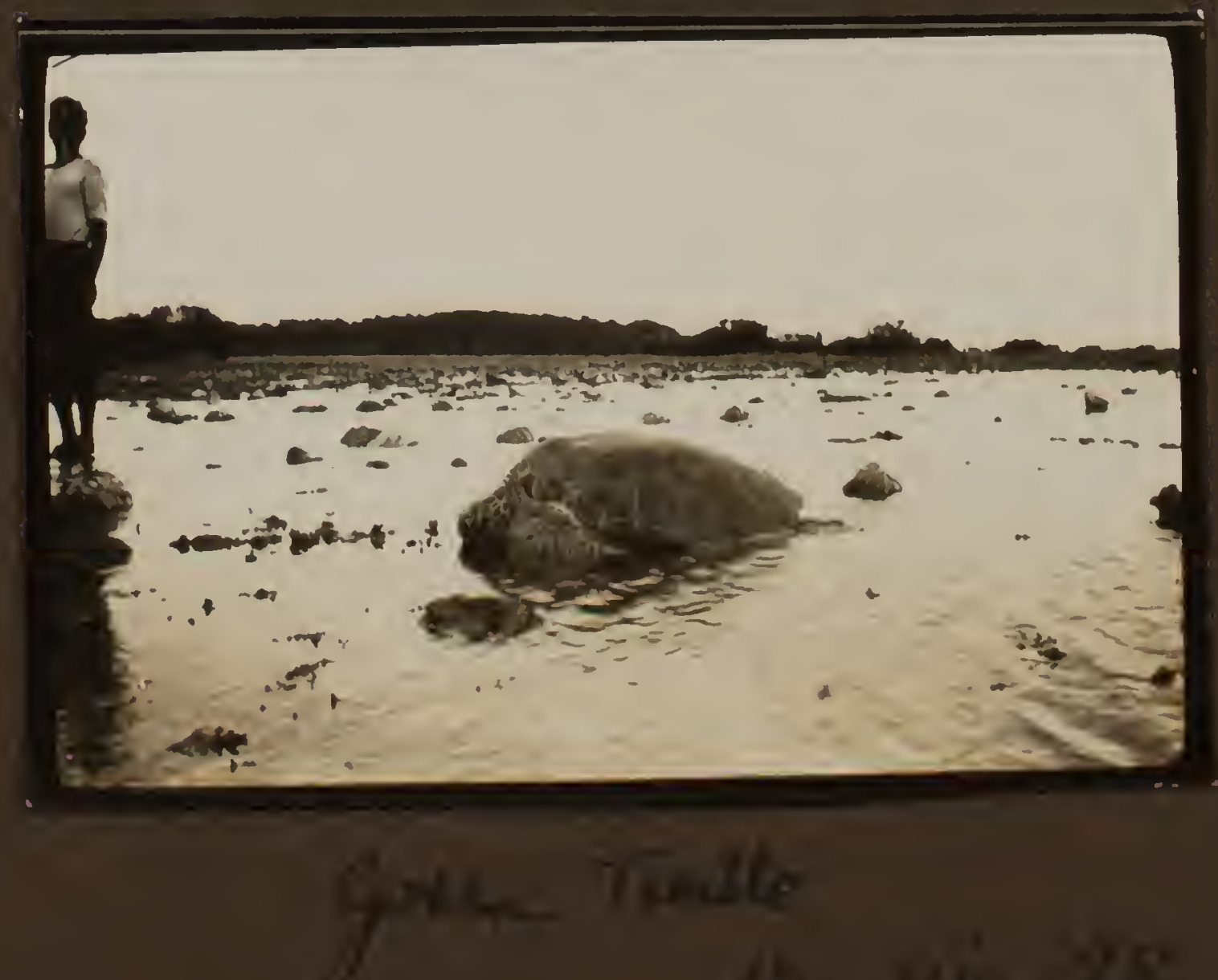


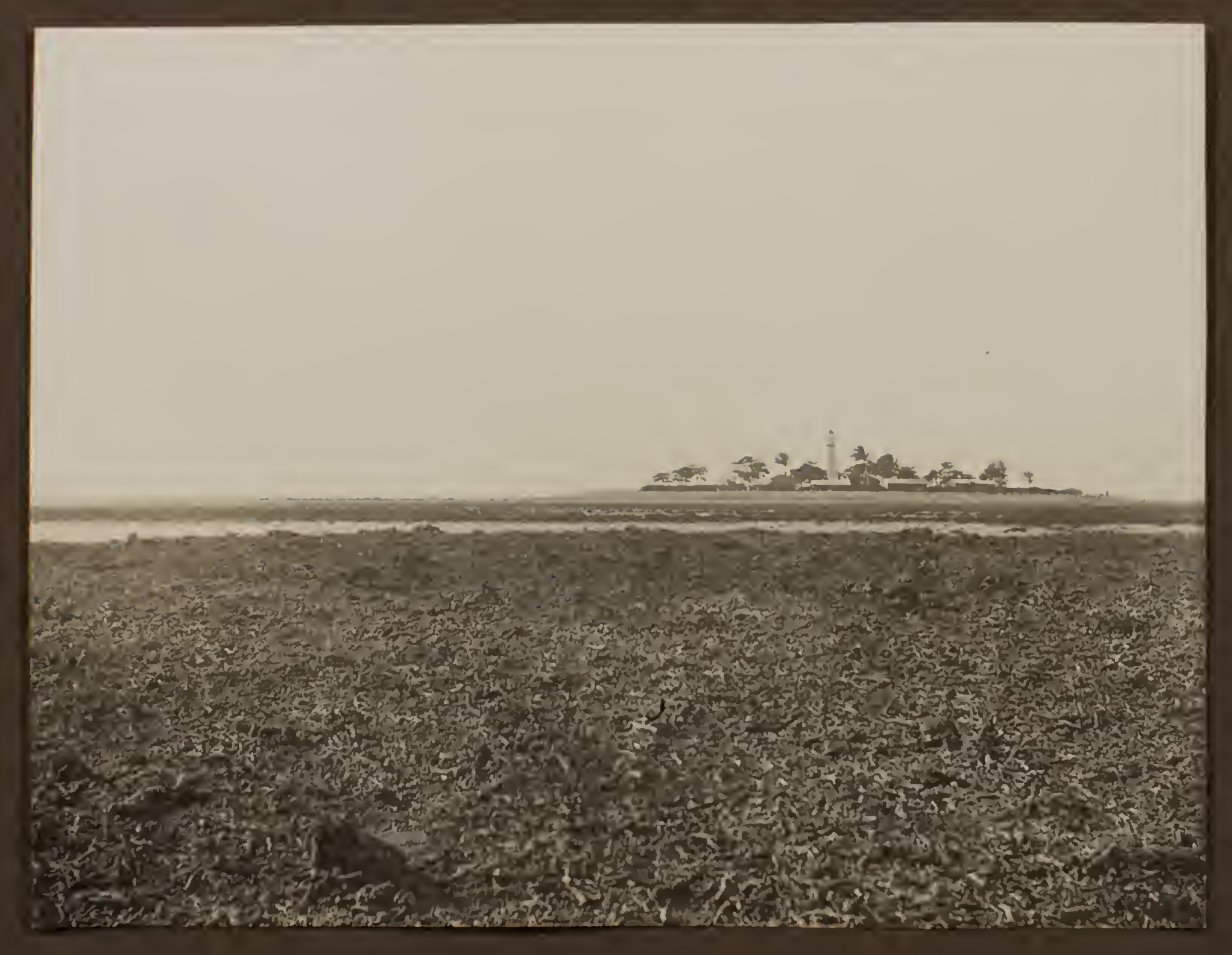

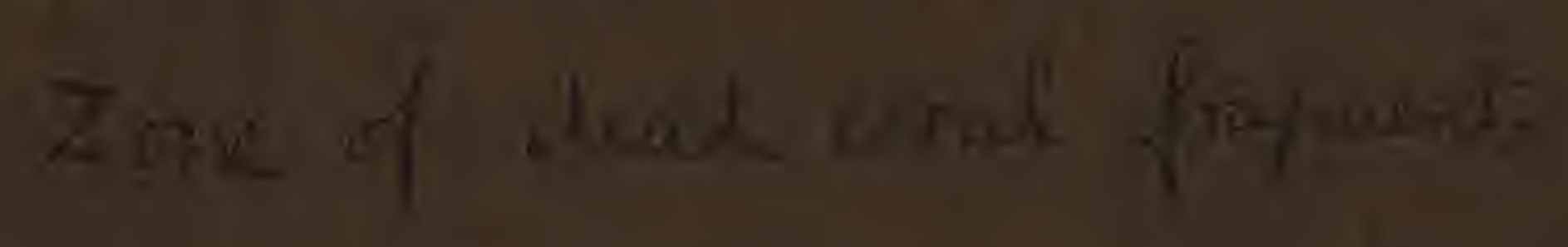




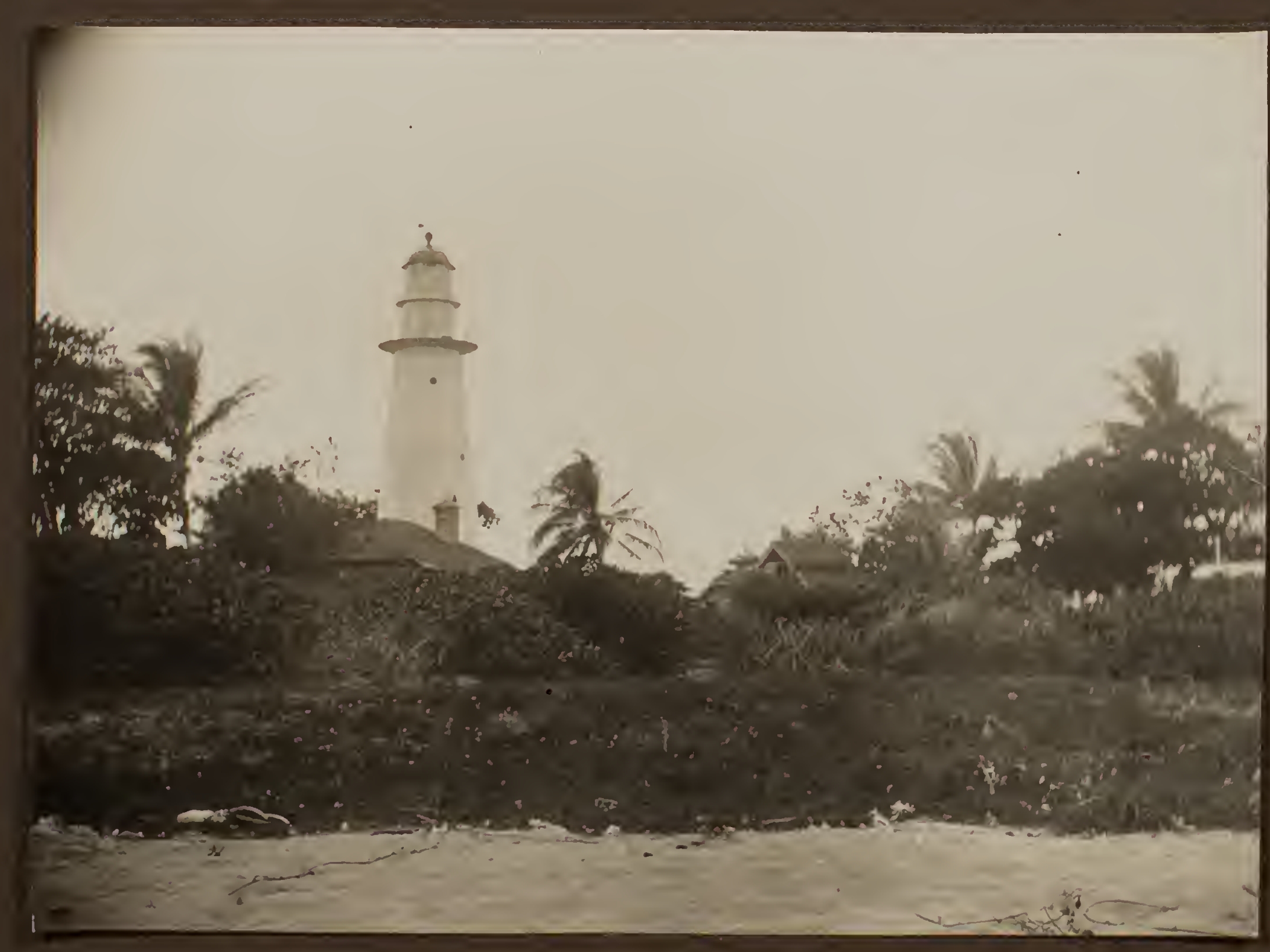


GBRMPA LIBRARY

||||||||||||||||||||||||||||

R007706

\# 7609

574.994

3

yord

1928

$v_{21}$ 


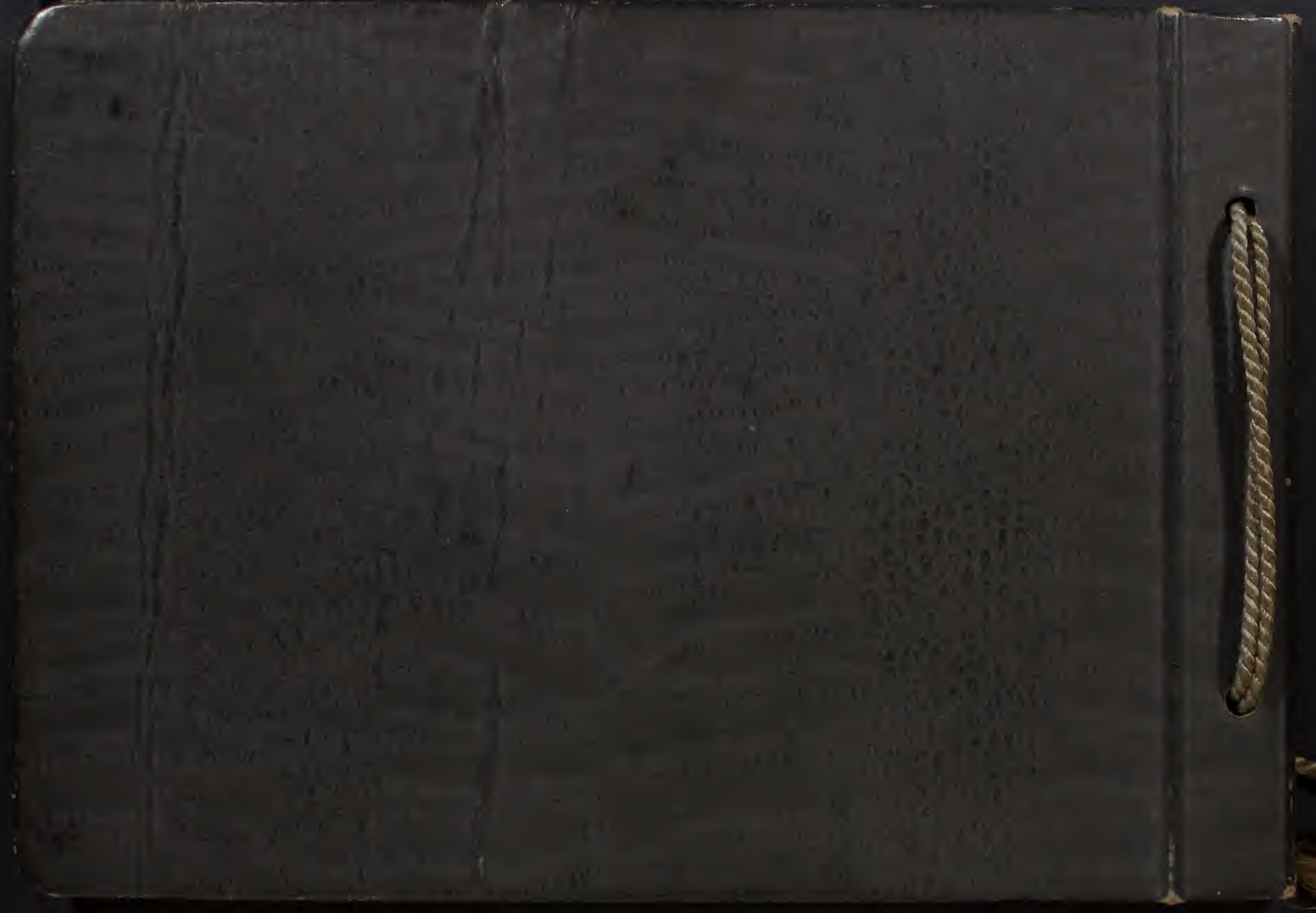

